\title{
Trilobite fauna (Wuliuan Stage, Miaolingian Series, Cambrian) of the lower Lakeview Limestone, Pend Oreille Lake, Idaho
}

\author{
Frederick A. Sundberg (1) \\ Research Associate, Museum of Northern Arizona, Flagstaff, Arizona 86001, USA < freddeb85@ cableone.net>
}

\begin{abstract}
The Lakeview Limestone is one of the westernmost Cambrian exposures in the northwestern United States and occurs on the western edge of the Montania paleotopographic high. These deposits occur between the deeper water deposits to the west and carbonate banks and intracratonic basins to the east and provide critical link between the regions. A re-investigation of the Cambrian trilobite faunas from the lower portion of the Lakeview Limestone, Pend Oreille Lake, Idaho, is undertaken due to the inadequate illustrations and descriptions provided by Resser (1938a). Resser's type specimens and additional material are figured and described. The trilobite assemblages represent the Ptychagnostus praecurrens Zone, Wuliuan Stage, Miaolingian Series and including two new taxa: Itagnostus idahoensis n. sp., and Utia debra n. sp. Because of the similarity between some species of Amecephalus from the Lakeview Limestone to specimens from the Chisholm Shale, Nevada, the type specimens of Amecephalus piochensis (Walcott, 1886) and Am. packi (Resser, 1935), Walcott's and Resser's type specimens are re-illustrate and their taxonomic problems are discussed. Utia curio Walcott, 1924 from the Spence Shale, Utah, have never been re-illustrated since Walcott (1925), these type specimens are also re-illustrated and compared to Utia debra $\mathrm{n}$. sp.
\end{abstract}

UUID: http://zoobank.org/5ef6ee5e-bddc-4395-becf-9bcea54c679c

\section{Introduction}

Perhaps one of Charles Resser's least cited papers is his 1938a publication on the Pend Oreille Lake fauna. This lack of use is most likely due to: (1) the $10.5 \times 17.5 \mathrm{~cm}$ plate with 58 tiny photographs, each smaller than a postage stamp (Fig. 1), severely limited the usefulness of the publication; and (2) Resser's (1939a, b) publications, both of which contained similar trilobites of similar age and were better illustrated. Resser (1938a) reported on the middle Cambrian fossils from the Lakeview Limestone and Rennie Shale adjacent to Pend Oreille Lake, Idaho. He named several species of brachiopods, hyolithids, and trilobites that had been collected by Edward Sampson during a survey of the Pend Oreille mining district in 1921 to 1924. Resser named and illustrated 13 new species and two previously named species of trilobites from the Lakeview Limestone exposed in the cliffs next to the Lakeview Cement mines (Fig. 2.1). Resser (1938a, p. 3) also reported Glossopleura pygidium presumably from the Lakeview Limestone and Tonkinella, although both are from unknown horizons within the Lakeview Limestone and the specimens were not figured.

The Pend Oreille locality is one of the westernmost Cambrian exposures in the northwestern United States between the deeper water deposits to the west and carbonate banks and intracratonic basins to the east (Bush et al., 2012). Given this geographic importance, the lack of detailed information of the assemblage, poor illustrations and descriptions, and conflicting age indicators (Glossopleura $=$ Glossopleura walcotti Zone,
Laurentian Delamaran Stage; Tonkinella = Ehmaniella Zone, Laurentian Topazan Stage; international Wuliuan Stage, Miaolingian Series), this paper focuses on the redescription and illustration of the trilobites and the biostratigraphy of the Lakeview Limestone. Resser's types are re-illustrated along with new specimens and previously unreported taxa from new collections made from the lower portion of the Lakeview Limestone.

\section{Stratigraphy and depositional setting}

The Lakeview Limestone consists of $\sim 600 \mathrm{~m}$ of limestone, shales, and dolostones that range from the middle to upper Cambrian (Motzer, 1980; Bush and Fischer, 1981; Bush, 1989; Bush et al., 2012). The Lakeview Limestone section was measured along the "steeply incised stream banks of Gold Creek" (Motzer 1980, p. 1; Fig. 2.1—orange and red line). Browne (2012) identified two concealed faults that intersect the measured section, one in the upper part of the formation and another in the lower part (Fig. 2.1), that were not recognized by Motzer (1980; Fig. 3). These faults may have altered the thicknesses of the Lakeview Limestone reported by Motzer and used herein. Browne did not include the Rennie Shale in his discussions, but this relatively thin $(30 \mathrm{~m})$ formation was probably included in his Lakeview Limestone.

The lower portion of the Lakeview Limestone is $335 \mathrm{~m}$ thick and is dominated by dark-gray, fossiliferous lime mudstones with interbedded calcareous shales (Fig. 3). The upper portion is $252 \mathrm{~m}$ and is dominated by nonfossilferous 


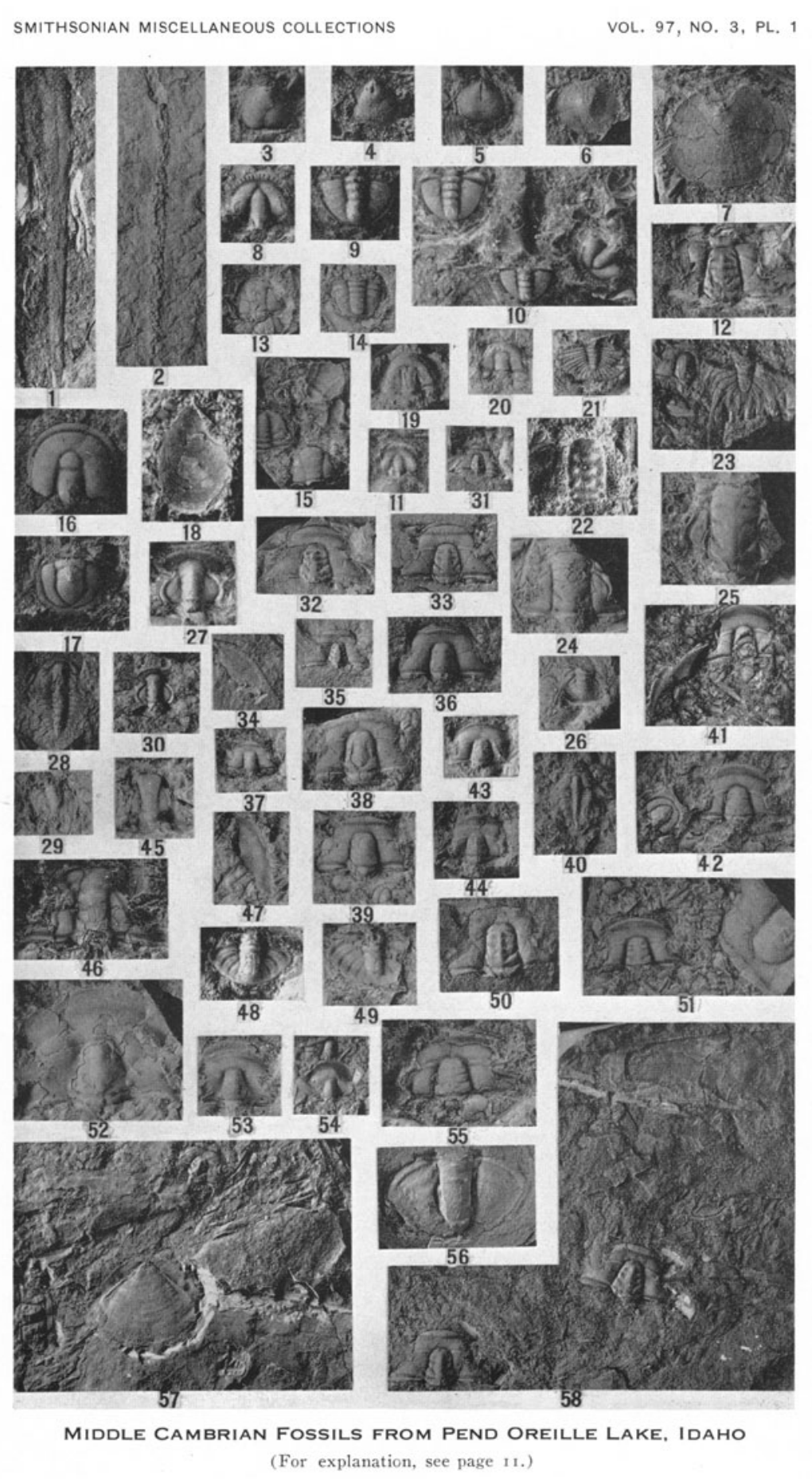

Figure 1. Reproduction of Resser's 1938a plate 1 at original size. Brightness and contrast has been adjusted to match the original printed plate. Specimen numbers 8-11, 16, 17, 19-21, 23, 28-30, 41-49, and 51-55 are trilobites from the Lakeview Limestone that are re-illustrated herein.

dolomudstones with interbedded oolitic and microbial dolostones. Six lithofacies are recognized in the Lakeview Limestone (Motzer, 1980; Bush, 1989; Bush et al., 2012), three of which are in the lower portion of the formation (in ascending order): parallel-laminated lime mudstone $(240 \mathrm{~m})$, nodular shale (55 m), and mottled limestone ( $40 \mathrm{~m}$ ) lithofacies. These lithofacies represent a shallowing-up sequence deposited in an anaerobic to aerobic environment below wave base (Motzer, 1980).
The fossils from the Lakeview Limestone reported by Resser (1938a) and here are from lithofacies 1 in the lower portion of the formation (Bush, 1989; Figs. 3-5). This portion of the Lakeview Limestone was deposited on the open ocean side of the middle carbonate belt in a deeper subtidal environment on the western edge of paleotopographic high called Montania (Bush et al., 2012; Fig. 2.3). To the west are the deeper water deposits of the structurally deformed Metaline Formation of northwest 


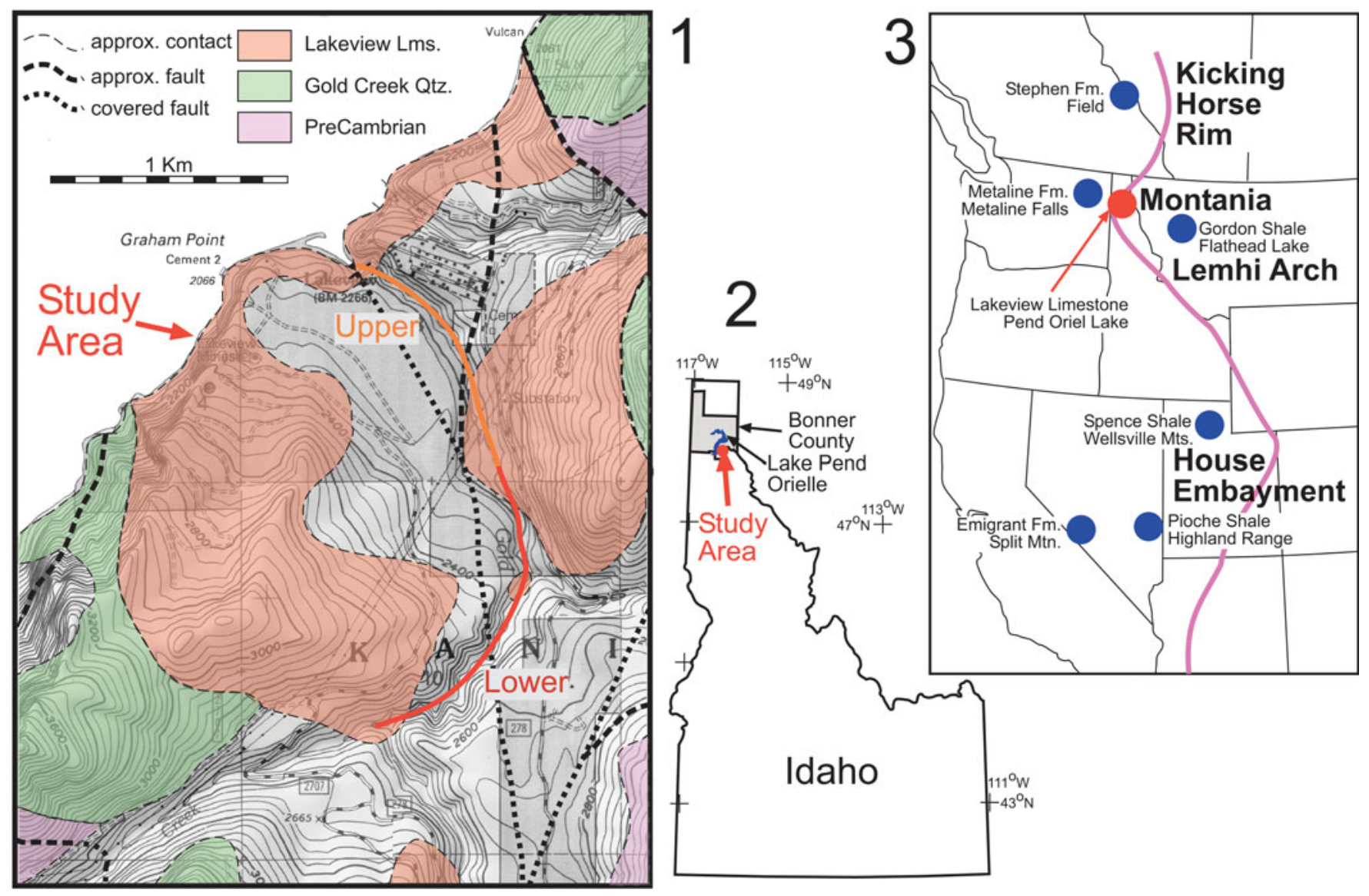

Figure 2. Location maps of the study area. (1) Location of the measured section of Lakeview Limestone along Gold Creek reported by Motzer (1980) and USNM Loc. 37n of Resser (1938a; = study area discussed herein). Motzer (1980) divided her measured section into the lower (red line) and upper (orange line) portion Lakeview Limestone. The geology is modified from Browne (2012) to show Precambrian and Cambrian formations and faults. Although unstated, Browne included the Rennie Shale in either the top of the Gold Creek Quartzite or the bottom of the Lakeview Limestone. Base map is part of the Lakeview 7.5' topographic quadrangle map, Bonner County, Idaho, USA. (2) Location of study area in the upper portion of Idaho. (3) Location of the study area (red dot) relative to the paleotopographic features defined by the limit of upper Precambrian and lower Cambrian strata (purple line; modified from Stewart, 1970) and locations discussed in the text (blue dots).

Washington State, and to the east are the bioturbated carbonates and inner detrital belt deposits of the Fishtrap Dolostone, Gordon Shale, and Wolsey Shale of Montana (Bush et al., 2012). In addition, to the north are the age-equivalent rocks of the Stephen Formation along the Kicking Horse Rim in British Columbia (Rasetti, 1951; Fig. 2.3). Age-equivalent rocks to the south include the Spence Shale, Wellsville Mountains and area, Utah (Resser, 1939a, b), near the House Embayment, and further south the Chisholm Shale, Pioche Hills (Sundberg, 2011b), and Emigrant Formation, Split Mountain (Sundberg, 2018), Nevada (Fig. 2.3).

\section{Biostratigraphy}

Middle Cambrian biostratigraphy of western Laurentia consists of a duel zonation, one based on agnostoid taxa that is generally used in deeper water settings and the other on polymerid taxa that is generally used in shallow water settings (Robison, 1976; Babcock et al., 2016). The agnostoid zonation is based on species; however, the polymerid zonation has traditionally been based on either a genus or genera. Revision of the Laurentian Delamaran Stage polymerid zonation to use first occurrence of species has been undertaken (Eddy and McCollum, 1998; McCollum and Sundberg, 2007; Sundberg, 2011a). Sundberg (1994) subdivided the Ehmaniella Zone of the Laurentian Topazan Stage into subzones based on genera. Robison (1964) divided the Bolaspidella Zone of the Laurentian Marjuman Stage into two subzones based on species. These zone concepts are used herein (Fig. 3) and previously used biostratigraphic units used by Resser (1938a, 1939a, b), Rasetti (1951), Robison and Campbell (1974), Palmer and Halley (1979), Motzer (1980), and Bush (1989, 1991; Bush and Fischer, 1981; Bush et al., 2012) have been modified to fit this biostratigraphic terminology.

Faunas of the lower Lakeview Limestone range from the Ptychagnostus praecurrens to Bolaspidella zones (Fig. 3), which are assigned to the international Wuliuan and Drumian stages, Miaolingian Series and the Laurentian Lincolnian Series, Delamaran to Marjuman stages of the Cambrian (Babcock et al., 2007; Zhao et al., 2019). These assignments are based on the taxa reported in Motzer (1980) that have been cited by Bush (1989, 1991; Bush and Fischer, 1981; Bush et al., 2012), and on the results presented here.

The fossil assemblages reported here from the lower portion of the Lakeview Limestone belong to the Ptychagnostus 


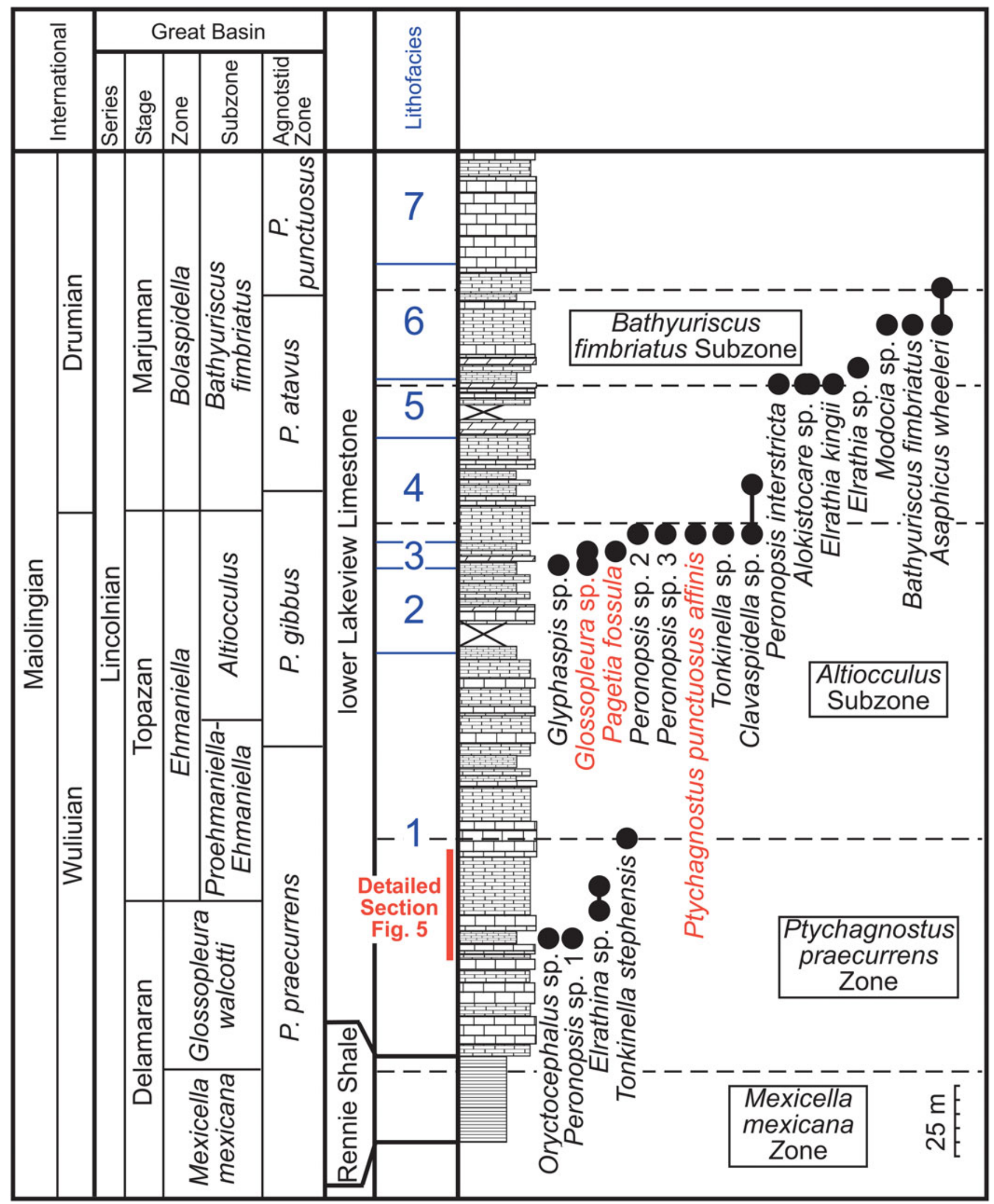

Figure 3. Stratigraphic section and trilobite ranges from the lower Lakeview Limestone modified from Motzer (1980). Biozonal assignments (boxed) are based on taxa reported by Motzer, although taxa in red provide conflicting information (see text). 

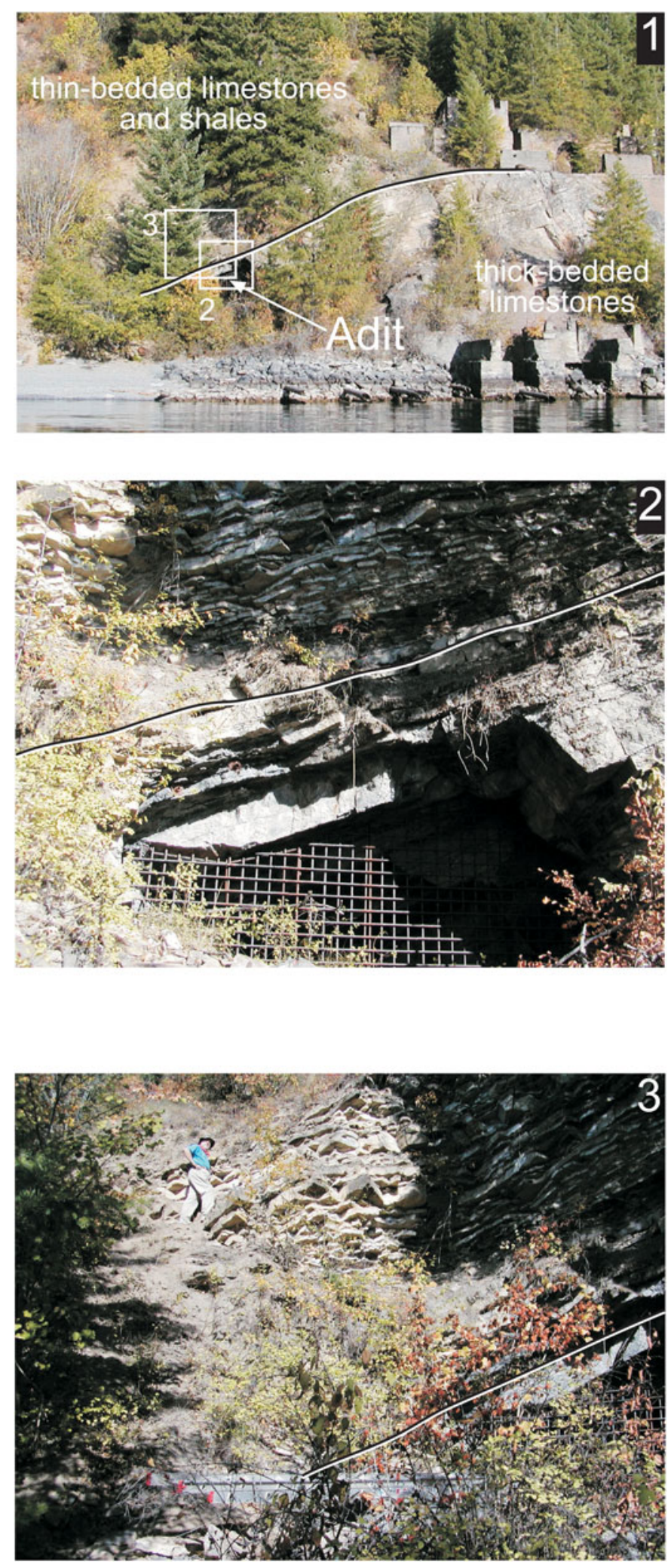

Figure 4. Outcrops of the Lakeview Formation along Pend Oreille Lake collected by Resser (1938a) and for this study. White and black line is the contact between the thick- to medium-bedded silty limestones and the overlying thinbedded micrites and shale intervals in Figure 5. (1) Section overview showing adit and location of photographs 2 and $3 ;(2)$ the adit in the upper $4 \mathrm{~m}$ of the thickbedded limestones and the overlying limestone and shale interval; (3) thinbedded limestones and shale sequence that yield the fossil collections discussed in this paper. praecurrens Zone based on Pentagnostus bonnerensis (Resser, 1938a) and is probably the co-equivalent Glossopleura walcotti Zone (see Sundberg, 2018). No Glossopleura taxa have been found in the lower Lakeview Limestone, however, the underlying Rennie Shale contains faunas of the Mexicella mexicana Zone (Harrison and Jobin, 1965) and Glossopleura (Resser,1938a), which indicates the Glossopleura walcotti Zone. This implies that the lower portion of the Lakeview Limestone represents the Glossopleura walcotti Zone. This zone assignment is also supported by the occurrence of Oryctocara geikiei Walcott, 1908, Oryctocephalites reynoldsi (Reed, 1899), Thoracocare minuta (Resser, 1939a), and Pagetia fossula Resser, 1938a (Fig. 5), which are also found in this zone in the Spence Shale, Langston Formation, and/or Emigrant Formation (see Sundberg, 2018).

Fossiliferous horizons at $\sim 140$ and $170-185 \mathrm{~m}$ above the base of the formation contain Tonkinella stephensis Kobayashi, 1935, Glyphaspis sp., and Tonkinella sp. These taxa occur in both the Stephen Formation (Rasetti, 1951; Fritz, 1968) and Swasey Limestone and correlatives in Utah and Nevada (Sundberg, 1994). These horizons correlate to the Altiocculus subzone, Ehmaniella Zone (Sundberg, 1994, 2005). However, the reported occurrence of Glossopleura sp. and Pagetia fossula would suggest that the assemblage represents the stratigraphically lower Glossopleura walcotti Zone. In contrast, Ptychagnostus punctuosus affinis (Brögger, 1878) would suggest the stratigraphically higher Ptychagnostus punctuosus Zone (Fig. 3). These conflicting data indicate that the faunas of this interval need to be restudied.

Fossiliferous horizons 230-265 m above the base of the formation contain Peronopsis interstricta (White, 1874), Elrathia kingii (Meek, 1870), Modocia sp., Bathyuriscus fimbriatus Robison, 1964, and Asaphiscus wheeleri Meek, 1873, which represent the Bathyuriscus fimbriatus Subzone, Bolaspidella Zone, and the Ptychagnostus atavus Zone (Laurentian Marjuman Stage, Lincolnian Series), international Drumian Stage, Miaolingian Series of the Cambrian (Babcock et al., 2007; Zhao et al., 2019). These taxa are found in the Wheeler Shale (Robison, 1964) and are the basis of the zonal assignment.

The upper Lakeview Limestone is unfossiliferous and the ages of the lithofacies (middle to upper Cambrian) are based on lithologic and grand cycle correlations to Montana (Bush, 1989; Bush et al., 2012).

\section{Preservation and abundance}

Nearly all of the specimens collected are disarticulated sclerites in packstones $<1 \mathrm{~cm}$, with only a few larger specimens. Sclerites are commonly unfragmented, but specimens with high relief tend to be flattened during compaction and display several fractures. Articulated specimens are rare.

Fossil material is abundant, with several thousand specimens. The relative abundance listed in the locality registrar is based on an estimate of how abundant specimens of different species are. For example, Pentagnostus bonnerensis is very abundant ( $>500$ specimens) and dominates most assemblages, with Pagetia fossula as abundant (100-500 specimens); Elrathina idahoensis (Resser, 1938a) is common (50-100 

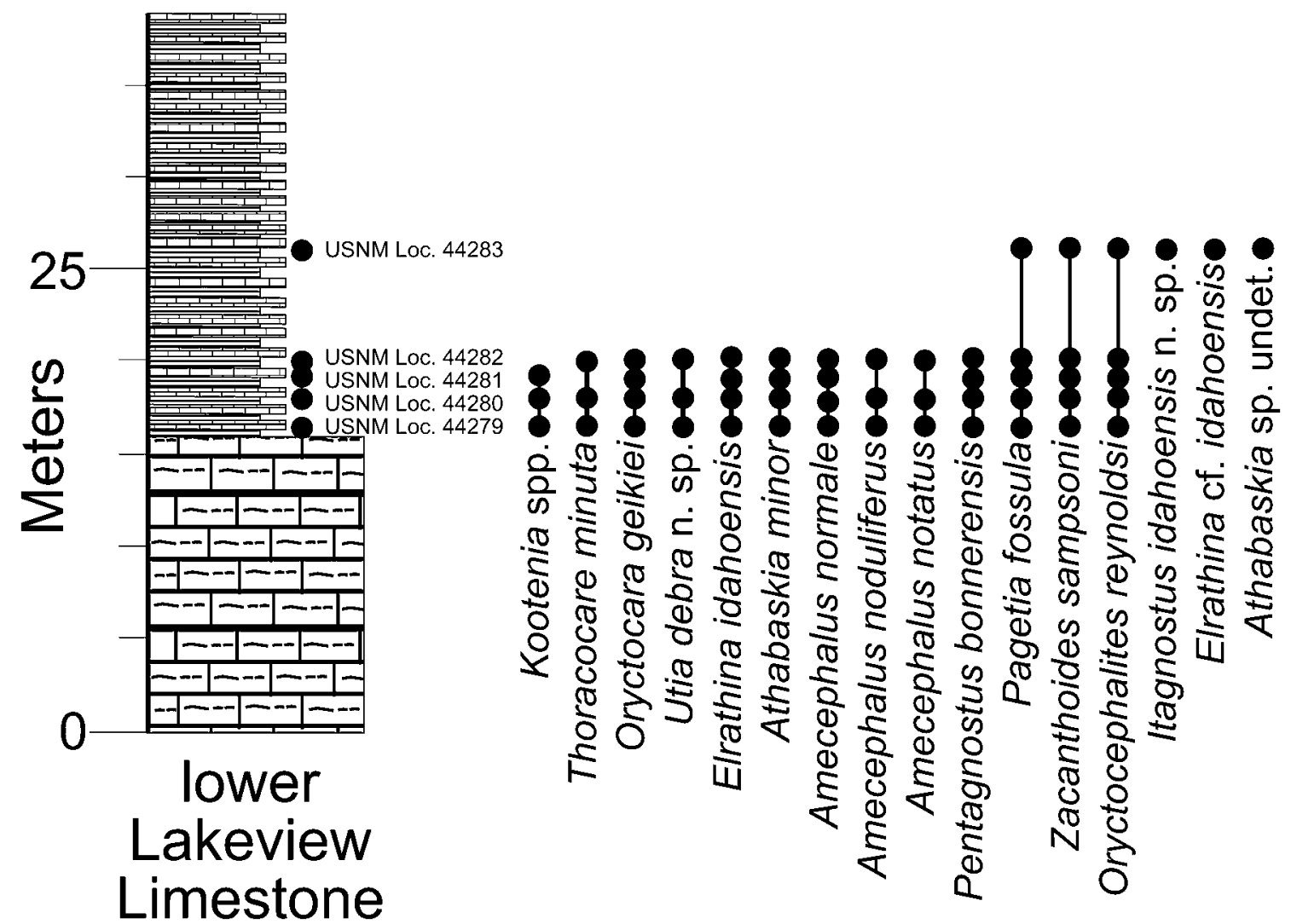

Figure 5. Stratigraphic section and trilobite ranges from the lower Lakeview Limestone from the Lakeview Cement Mine area illustrated in Figures 3 , 4.

specimens) in the fossil horizons; Amecephalus normale (Resser, 1938a) is rare (10-50 specimens); and Utia debra n. sp. is very rare $(<10$ specimens). Of course, the relative abundance is partially based on the size of the samples from each horizon, which range from $3-15 \mathrm{~kg}$.

\section{Materials and methods}

Illustrated specimens were coated with colloidal graphite and then ammonium chloride sublimate for photography except for the previous type specimens of Resser (1938a) and Walcott (1924), which were only coated with ammonium chloride sublimate. Morphometric analyses were undertaken using linear measurements illustrated by Sundberg and McCollum (1997, fig. 7; 2003, fig. 6), principal component analysis (PCA), and landmark methods as outlined by Webster and Sheets (2010).

Repository and institutional abbreviation.-All specimens have been deposited at the National Museum of Natural History (USNM).

\section{Systematic paleontology}

All type specimens come from the Lakeview Limestone on the east shore of Pend Oreill Lake, Idaho, unless otherwise stated.

Order Agnostida Salter, 1864

Suborder Agnostina Salter, 1864

Superfamily Agnostoidea M'Coy, 1849
Family Peronopsidae Westergård, 1936

Genus Pentagnostus Lermontova, 1940

Type species.-Pentagnostus anabarensis Lermontova, 1940, from the Anabar region (exact location or formation not listed on specimen labels or in text; E.L. Naimark, personal communication, 2017), Siberia, by original designation.

Diagnosis.—See Laurie (2004).

\section{Pentagnostus bonnerensis (Resser, 1938a)}

Figures 6, 7

1938a Agnostus bonnerensis Resser, p. 6, pl. 1, figs. 16, 17.

1939a Agnostus bonnerensis; Resser, p. 8, pl. 2, figs. 24-26.

1939a Vistoia? minuta Resser, p. 21, pl. 2, fig. 1 only.

1979 Peronopsis bonnerensis; Palmer and Halley, p. 76, pl. 12, figs. 11, 15.

2012 Pentagnostus (Meragnostus) bonnerensis; Naimark, figs. 16a, b.

2018 Pentagnostus brighamensis; Sundberg, p. 6, fig. 6.1-6.16.

Holotype.-Pygidium USNM 156547 from USNM loc. 37n.

Paratypes.-USNM 156548, 156548a, 95025-95025c from USNM loc. 37n.

Diagnosis. - Cephalon with low inflation; preglabellar median furrow absent, glabella well defined and gently sloping 

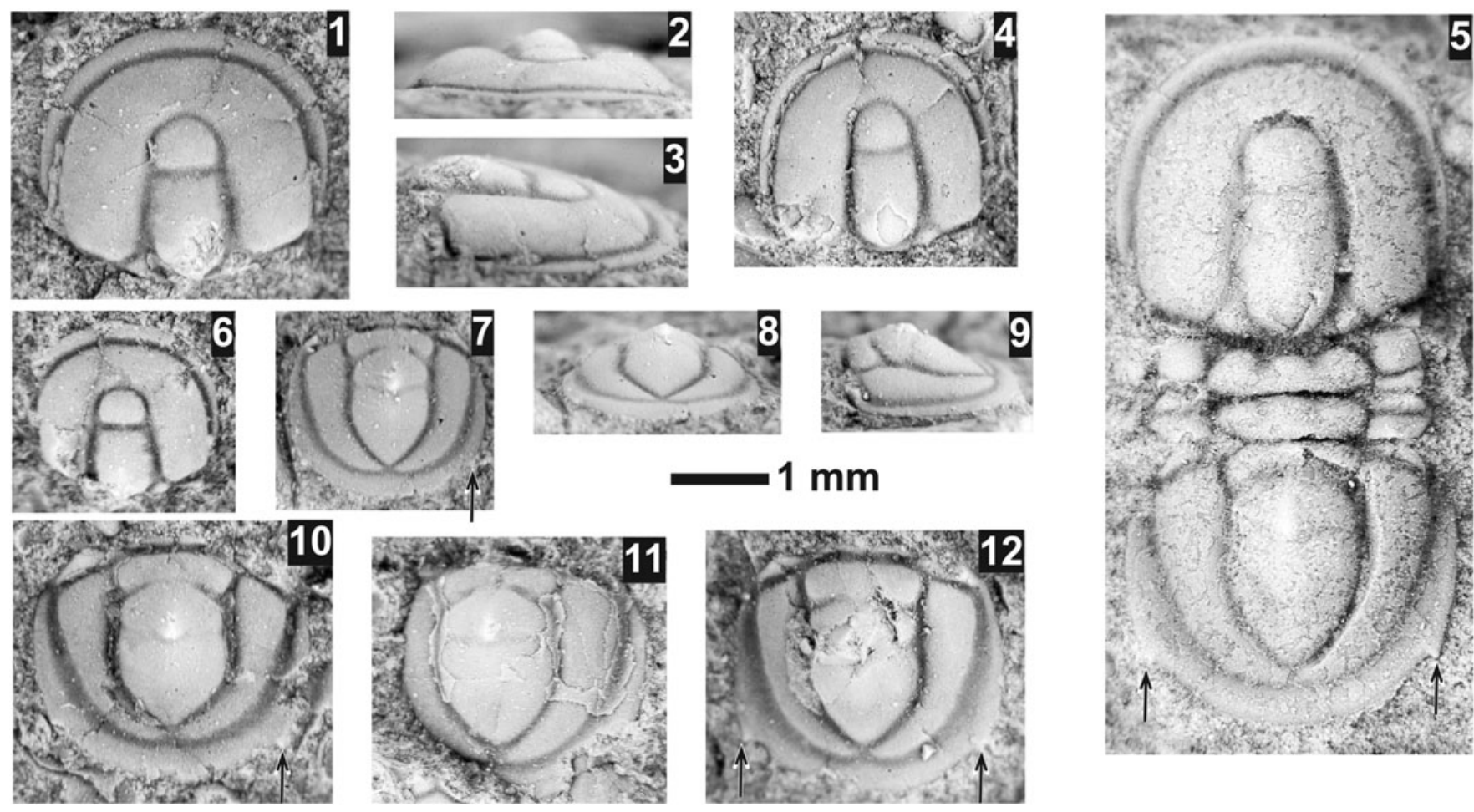

Figure 6. Pentagnostus bonnerensis (Resser, 1939a) from the Ptychagnostus praecurrens Zone, Lakeview Limestone, Pend Oreille Lake, Idaho. All specimens are Resser's type specimens from USNM loc. 37n, except (5), which is from USNM loc. 44279. Arrows indicate small posterolateral spines. (1-3) Mostly exfoliated paratype cephalon USNM 156548a, dorsal, anterior, and lateral views; (4) exfoliated, previously un-illustrated paratype cephalon USNM 156548; (5) latex cast of mostly exfoliated shield USNM 724156; (6) mostly testate, previously un-illustrated paratype cephalon USNM 95025b; (7-9) mostly exfoliated holotype pygidium USNM 156547, dorsal, posterior, and lateral views; (10) mostly exfoliated, previously un-illustrated paratype pygidium USNM 95025a; (11) mostly exfoliated, previously un-illustrated paratype pygidium USNM 95025c; (12) mostly exfoliated, previously un-illustrated paratype pygidium USNM 95025.

downward from weakly developed median node to frontal lobe; anterior lobe subrectangular, well defined with moderately deep and straight F3 furrow. Pygidium with low inflation; axial lobe well defined with deep axial furrows, moderately long; well-developed F1 furrow, directed anterolaterally, shallower medially; F2 furrow shallow to nearly effaced, straight to bending slightly posteriorly; moderate size median tubercle, with highest portion at posterior margin of M2; M3 with low convexity; terminus bluntly rounded, reaching the posterior border furrow in smaller specimens, nearly reaching the furrow in larger specimens; shallow to moderate postaxial median furrow in smaller specimens; border relatively wide (trans, sag.), with small marginal spines.

Occurrence.-Lakeview Limestone (Ptychagnostus praecurrens Zone), Pend Oreille Lake, Idaho. Spence Shale (Glossopleura walcotti Zone), Two Mile Canyon, Malad Range and Wasatch Mountains, Utah (Resser, 1939a; Campbell, 1974). Red Pass Limestone member, Carrara Formation (Mexicella mexicana Zone), Belted Range, Nevada (Palmer and Halley, 1979). Emigrant Formation (Glossopleura walcotti/Ptychagnostus praecurrens Zone), Split Mountain, Nevada (Sundberg, 2018).

Description.-Cephalon $(\mathrm{N}=11)$ and pygidium $(\mathrm{N}=20) 3.5$ to $4.4 \mathrm{~mm}$ long; nonscrobiculate; surface smooth. Cephalon rounded to weakly subquadrate, $91 \pm 4 \%$ as long as wide, nonspinose, low inflation; border narrow, slightly convex; border furrow well developed, very narrow; preglabellar median furrow absent. Glabella well defined by moderately deep axial furrow, gently down sloping from weakly developed median node to frontal lobe, length $67 \pm 3 \%$ as long as cephalon; anterior lobe well defined, subrectangular, rounded anteriorly, occupying $33 \pm$ $3 \%$ of glabellar length. F3 furrow well defined, straight or bowed slightly anteriorly; posterior glabellar lobe subrectangular with very weak taper, moderately inflated in its posterior half, F2 furrows very weakly developed as faint notches indenting lobe margin. F1 furrows very weakly developed as slight indentations about level with anterior extremities of basal lobes; glabellar node located about midway between F1 and F2 furrows; basal lobes small, with a broad (tr.) bulbous posterior portion and a narrow (tr.), depressed anterior portion.

Hypostome unknown.

Pygidium rounded to weakly quadrate, $90 \pm 3 \%$ as long as wide, low inflation, with small posterolateral spines; border of moderate width, wider posteriorly, flattened; border furrow distinct, narrow; postaxial median furrow variably developed, ranging from broad and clearly defined in smaller specimens to only being evident anteriorly to absent in larger specimens. Axis well defined with deep axial furrows, $68 \pm 4 \%$ as wide as long and 74 $\pm 4 \%$ of pygidial length, constricted across $\mathrm{F} 2$, posteriorly angular to slightly rounded, moderately low convexity. F1 furrow strong laterally and shallower medially; bent anteriorly. M1 lobe width $45 \pm 3 \%$ pygidial width, lateral margins convex, converging posteriorly. F2 furrow shallow to nearly effaced; straight or bending slightly posteriorly; M2 lobe constricted with 

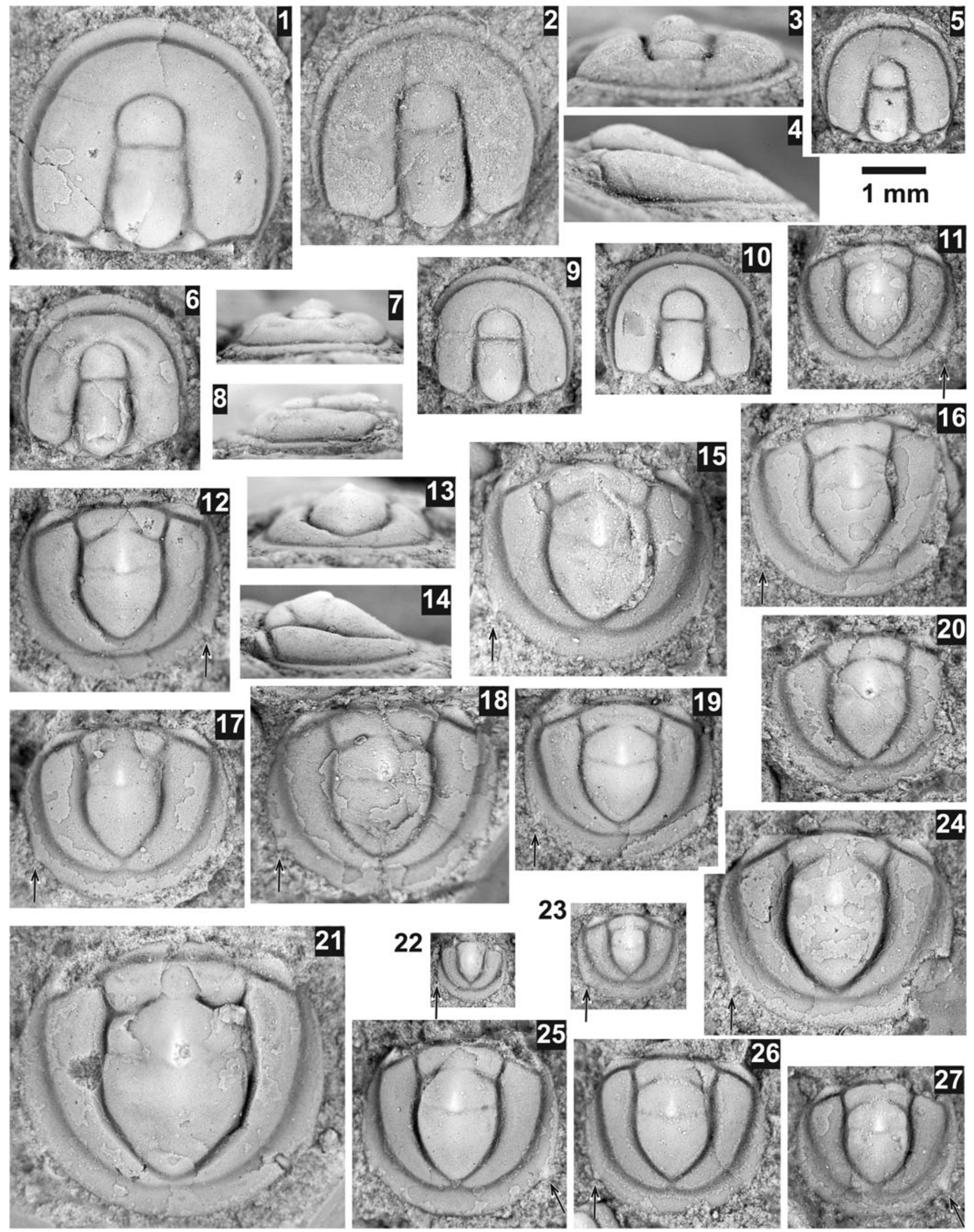

23
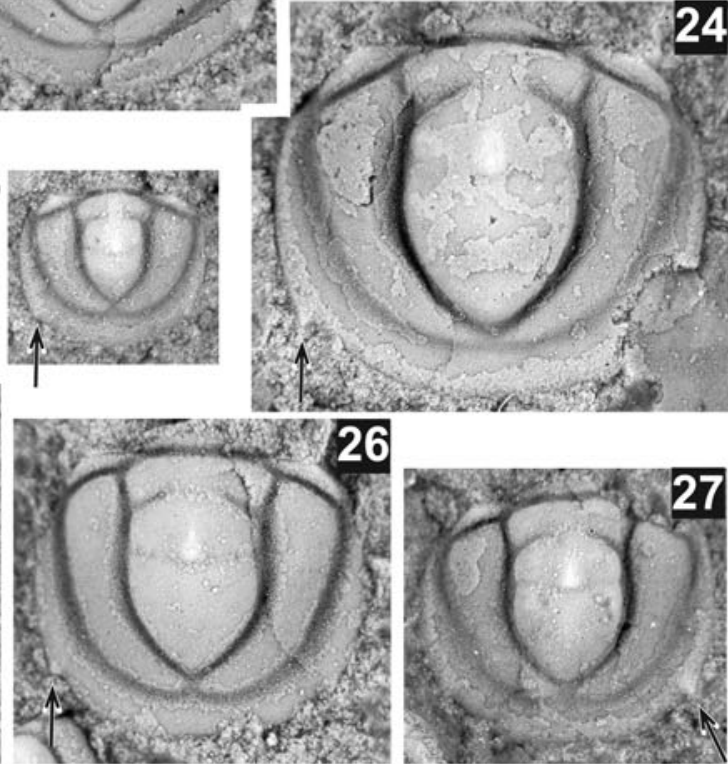
Figure 7. Pentagnostus bonnerensis (Resser, 1939a) from the Ptychagnostus praecurrens Zone, Lakeview Limestone, Pend Oreille Lake, Idaho. All specimens are from USNM loc. 44279. Arrows indicate small posterolateral spines. (1) Mostly exfoliated cephalon USNM 724151, (2-4) exfoliated cephalon USNM 724139, dorsal, anterior, and lateral views; (5) mostly exfoliated cephalon USNM 724148; (6-8) mostly exfoliated cephalon USNM 724135, dorsal, anterior, and lateral views; (9) mostly exfoliated cephalon USNM 724146; (10) mostly testate cephalon USNM 724152; (11) mostly exfoliated pygidium USNM 724154; (12-14) mostly testate pygidium USNM 724136, dorsal, posterior, and lateral views; (15) mostly exfoliated pygidium USNM 724143; (16) mostly testate pygidium USNM 724141; (17) mostly exfoliated pygidium USNM 724140; (18) mostly exfoliated pygidium USNM 724137; (19) mostly testate pygidium USNM 724153; (20) mostly exfoliated pygidium USNM 724138; (21) mostly exfoliated pygidium USNM 724155 illustrating very weak posterolateral spines and very weak median postaxial furrow; (22) mostly testate pygidium USNM 724142; (23) exfoliated pygidium USNM 724150; (24) mostly exfoliated pygidium USNM 724147; (25) mostly exfoliated pygidium USNM 724145; (26) exfoliated pygidium USNM 724144; (27) mostly exfoliated pygidium USNM 724149.

margins slightly convex and converging slightly anteriorly. Axial node of moderate size, slightly elongate, highest at posterior margin of M2. Posteroaxis (M3) with low convexity, occupying $50 \pm 4 \%$ of axial length, with maximum width $41 \pm 3 \%$ pygidial width near anterior extremity of lobe; terminus angular to slightly rounded, reaching the posterior border furrow in smaller specimens, nearly reaching the furrow in larger specimens.

Remarks.-Resser (1938a) provided no differential diagnosis, only a comment that its characteristics "place it between $A$. montis Matthew [1899]... and A. interstrictus White [1874]..." (Resser, 1938a, p. 6) and that it was similar to an undescribed species from the Spence Shale, but differed in having an axial furrow on the pygidium.

Pentagnostus bonnerensis is similar to P. brighamensis from the Spence Shale, but differs in the pygidium having a higher convexity, longer axis that nearly reaches the border furrow, with the posterior lobe as wide as the M1, F1 nearly effaced, and F2 nearly effaced and curved posteriorly. Both species have poorly developed posterolateral nodes (Robison, 1978, pl. 1, figs 7, 11, 14), with $P$. bonnerensis having slightly weaker nodes (Figs. 6, 7; arrows). Sundberg (2018) also stated that the two species differed in that $P$. bonnerensis lacked a postaxial median furrow. However, topotypes of $P$. bonnerensis show a strongly to weakly developed postaxial median furrow in smaller specimens (Fig. 7.22, 7.23). Resser (1939b, p. 8) mentioned the "more circular outline for both shields" in the latter species, but this could be the result of compression in shale. However, limestone/silicified specimens (Robison, 1978) have a more elongate cephalon and pygidium when compared to $P$. bonnerensis.

Pentagnostus bonnerensis is similar to P. lautus (Resser, 1939 b) from the Spence Shale, but differs in the pygidium having a shallower F1 and nearly effaced F2, blunter end to the axis, and lacking a post axial furrow. The cropped pictures of Resser (1939b, pl. 2, figs 17, 18) do not show the small marginal spine, but the specimen in the bottom right of Resser (1939b, pl. 2, fig. 16) does illustrate these small spines.

Pentagnostus bonnerensis is similar to ?Euagnostus aff. E. taijiangensis (Huang and Yuan, 1994) of Laurie (2006, p. 148, fig. 20), but differs in the pygidium having a slightly shorter axis that does not reach the border furrow, a slight constriction of the axis at the M2 position, absence of a postaxial median furrow in larger specimens, and a weaker development of the posterolateral spines. Laurie (2006, p. 150) was uncertain about the assignment of his Australian material to ?E. taijiangensis due to the poor preservation of the type material.
Genus Itagnostus Öpik, 1979

Type species.-Agnostus elkedraensis Etheridge, 1902, from the Northern Territory, Australia.

Diagnosis._See Laurie (2004).

Itagnostus idahoensis new species Figure 8

2018 Pentagnostus bonnerensis (Resser, 1938a); Sundberg, p. 9, fig. 7.1-7.3.

Holotype.-Pygidium USNM 724035 from USNM loc. 44283.

Paratypes.-USNM 724025-724034, 724036-724049 from USNM loc. 44283.

Diagnosis. - Cephalon rounded with lateral margins convex; minute, advanced posterolateral spines; a relatively narrow border with narrow, well-defined border furrows. A well-rounded, inflated pygidium with a long axis not reaching border furrow, without secondary pygidial axial node; M3 with expanded, approximately equal to or greater than axial width in larger specimens, moderately rounded termination; minute marginal spines.

Occurrence.-Lakeview Limestone (Ptychagnostus praecurrens Zone), Pend Oreille Lake, Idaho. Emigrant Formation (Glossopleura walcotti/Ptychagnostus praecurrens Zone), Split Mountain, Nevada (Sundberg, 2018).

Description.-Cephalon $(\mathrm{N}=11)$ and pygidium $(\mathrm{N}=12)$ up to $3.5 \mathrm{~mm}$ long, nonscrobiculate, smooth. Cephalon moderately inflated, rounded to weakly subquadrate, $87 \pm 4 \%$ as long as wide, short posterolateral spines; border narrow, slightly convex; border furrow well developed, very narrow; preglabellar median furrow absent. Glabella well defined by moderately deep axial furrows, $73 \pm 2 \%$ as long as cephalon, down sloping from top of median node to anterior lobe; anterior lobe well defined, subrectangular, rounded anteriorly, occupying $34 \pm 1 \%$ of glabellar length; F3 furrow well defined, straight; posterior glabellar lobe subrectangular with very weak forward taper, strongly inflated in its posterior half, F2 furrows very weakly developed as very faint notches indenting lobe margin. F1 furrows very weakly developed as very slight indentations slightly anterior of the basal lobes; glabellar node located about midway between the F1 and F2 

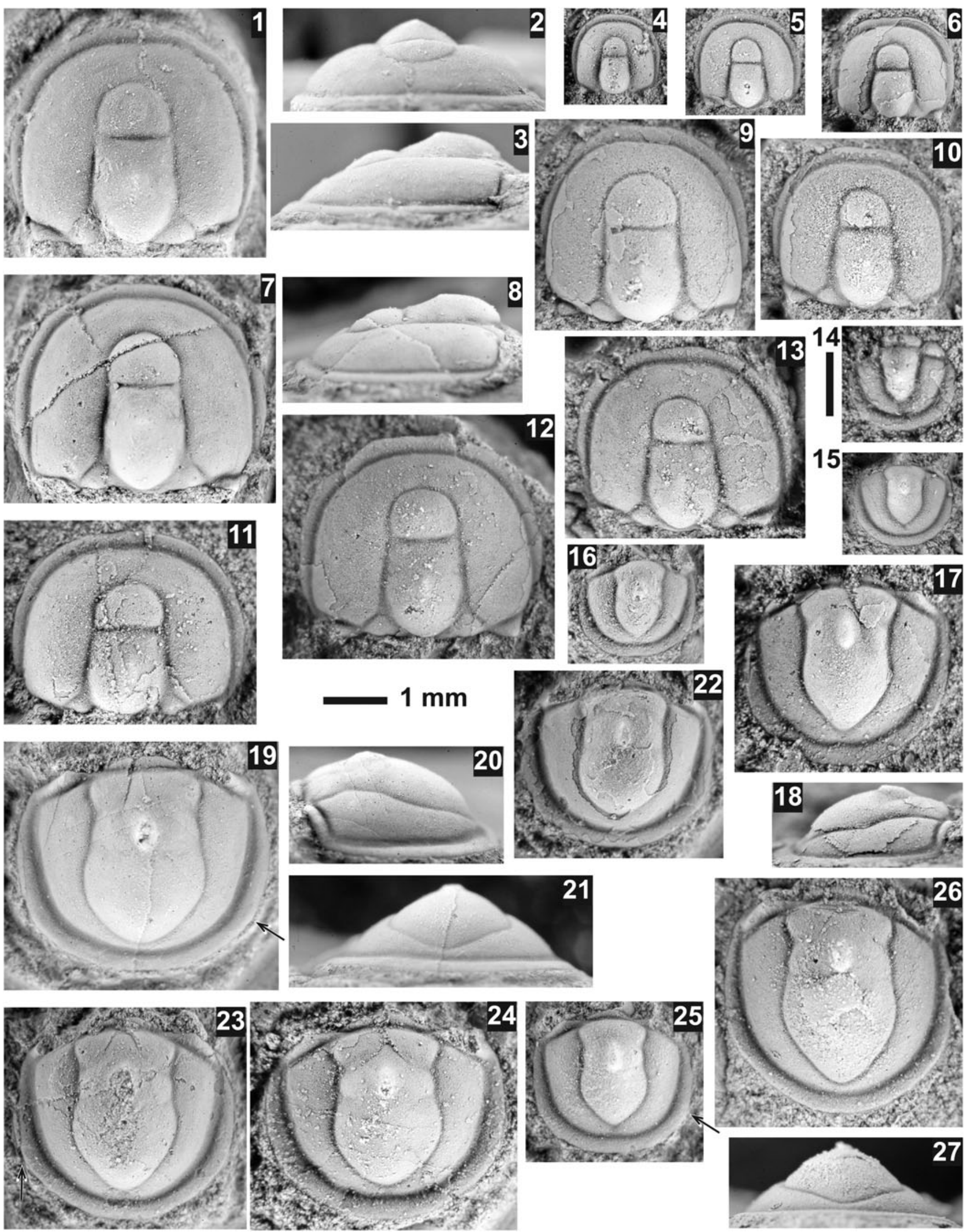
Figure 8. Itagnostus idahoensis n. sp. from the Ptychagnostus praecurrens Zone, Lakeview Limestone, Pend Oreille Lake, Idaho. All specimens are from USNM loc. 44283. Scale bar for (14) is $0.5 \mathrm{~mm}$. Arrows indicate very slight posterolateral nodes. (1-3) Exfoliated paratype cephalon USNM 724036, dorsal, anterior, and lateral views; (4) exfoliated, small paratype cephalon USNM 724039; (5) mostly exfoliated cephalon USNM 724031; (6) partly testate paratype cephalon USNM 724044; (7, 8) exfoliated paratype cephalon USNM 724025, dorsal and lateral views; (9) mostly exfoliated paratype cephalon USNM 724048; (10) mostly exfoliated paratype cephalon USNM 724032; (11) mostly exfoliated paratype cephalon USNM 724029; (12) mostly exfoliated paratype cephalon USNM 724030; (13) mostly exfoliated paratype cephalon USNM 724028; (14) mostly exfoliated, small paratype pygidium USNM 724045 illustrating median postaxial furrow reaching the posterior border furrow; (15) mostly exfoliated, small paratype pygidium USNM 724041 illustrating median postaxial furrow not reaching the posterior border furrow and weakly developed F3 furrow; (16) mostly exfoliated, small paratype pygidium USNM 724038 illustrating very weak median postaxial furrow not reaching the posterior border furrow; $(\mathbf{1 7}, \mathbf{1 8})$ mostly testate paratype pygidium USNM 724027 illustrating very weak median postaxial furrow, dorsal and lateral views; $(\mathbf{1 9 - 2 1 )}$ exfoliated holotype pygidium USNM 724035, dorsal, lateral, and posterior views; (22) mostly testate paratype pygidium USNM 724042; (23) mostly testate paratype pygidium USNM 724037; (24) mostly exfoliated paratype pygidium USNM 724026; (25) exfoliated paratype pygidium USNM 724046 illustrating very weak median postaxial furrow; (26, 27) exfoliated paratype pygidium USNM 724033, dorsal and posterior views.

furrows; basal lobes small, broad (tr.), bulbous, nearly triangular.

Hypostome and thorax unknown.

Pygidium rounded to weakly quadrate, $90 \pm 4 \%$ as long as wide, moderately inflated, with minute spines; border of moderate width, narrowing anteriolaterally, slightly convex; border furrow distinct, narrow; postaxial median furrow faint in smaller specimens, absent in medium to larger specimens. Axis well defined by moderately deep furrow, $65 \pm 4 \%$ as wide as long and $77 \pm$ $6 \%$ of pygidial length, constricted across $\mathrm{F} 1$, posteriorly variably rounded, moderately convex. F1 furrow very weak laterally and effaced medially; bent anteriorly. M1 lobe width $45 \pm 3 \%$ pygidial width, lateral margins convex, converging posteriorly. F2 furrow very shallow laterally, effaced medially; bending slightly posteriorly; M2 lobe constricted with margins slightly convex and weakly converging anteriorly. Axial node of moderate size, slightly elongate, highest portion at near midlength of M2. Posteroaxis (M3) with moderate convexity, occupying $51 \pm 4 \%$ of axial length, with maximum width $44 \pm 7 \%$ pygidial width near middle of lobe, width $97 \pm 11 \%$ axial width, with lower proportion $(\sim 80 \%)$ in smaller specimens and higher proportion $(\sim 100 \%)$ in larger specimens $\left(R^{2}=0.887\right.$; Fig. 9); terminus variably rounded, nearly reaching the border furrow.

Etymology.—Named for the State of Idaho.

Remarks. - Laurie (2004) provided a revised diagnosis of the genus. Some of the key cephalic features in Itagnostus idahoensis $\mathrm{n}$. sp. are the absence of the preglabellar median furrow, semiovate anterior lobe, straight F3, weak to absent F2, and location of the glabellar node. Similar pygidial

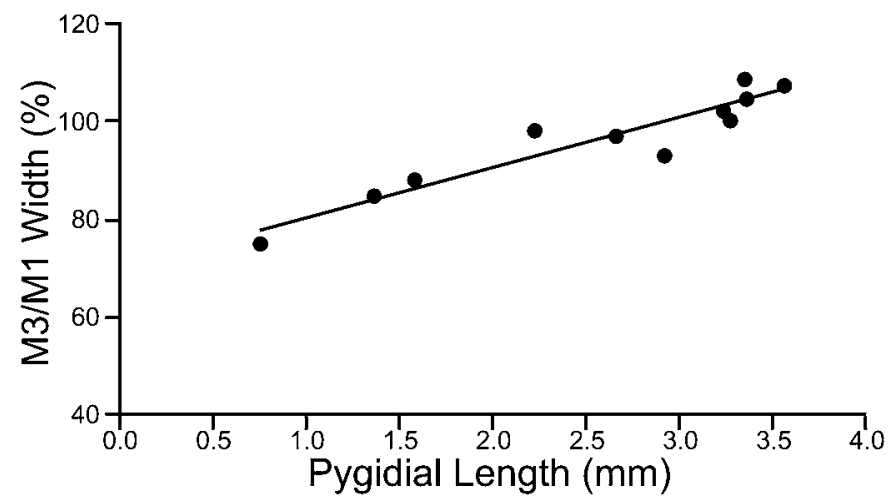

Figure 9. Bivariate plot of posterolobe (M3) width relative to axial width (M1) versus pygidial length in Itagnostus idahoensis $\mathrm{n}$. $\mathrm{sp}$. features include the long axis, broad with semiovate posterior lobe, and nearly effaced axial furrows. Itagnostus idahoensis n. sp. has a cephalon with small posterolateral spines, and pygidia with very small marginal spines, and lacking a postaxial furrow. The list of species assigned to the genus varies among authors (e.g., Laurie, 2004; Naimark, 2012; Naimark and Pegel, 2017), so comparison of I. idahoensis n. sp. is limited to the most similar species.

Itagnostus idahoensis $\mathrm{n}$. $\mathrm{sp}$. is similar to I. montis (Matthew, 1899) from the Stephen Formation (Ehmaniella Zone, Rasetti, 1951). Unfortunately, all specimens of I. montis are flattened in shale (Rasetti, 1951, pl. 25, figs. 11-14), which makes comparison of the two species difficult. Some apparent differences are I. idahoensis $\mathrm{n}$. $\mathrm{sp}$. has a cephalon with a more anteriorly located axial node and posterolateral spines not being advanced, and the pygidium having straighter lateral sides.

Itagnostus idahoensis n. sp. differs from I. elkedraensis (Laurie, 2004, fig. 12) in the cephalon having a broader axis and pygidium with smaller marginal spines and more expanded (trans.) M3. Itagnostus idahoensis $\mathrm{n}$. $\mathrm{sp}$. is very similar to I. walleyae Laurie, 2004, but differs in the cephala having continuous F3 of nearly uniform depth, more advanced, smaller posterolateral spines, and the pygidium having a more inflated lateral profile and lacking a secondary axial node. Itagnostus idahoensis n. sp. differs from I. oepiki Laurie, 2004, in having a more rounded cephalon and pygidium and in lacking a secondary pygidial node.

Suborder Eodiscina Kobayashi, 1939

Superfamily Eodiscoidea Raymond, 1913

Family Eodiscidae Raymond, 1913

Genus Pagetia Walcott, 1916b

Type species.-Pagetia bootes Walcott, 1916b, from the Stephen Formation, Mount Field, British Columbia, by original designation.

Diagnosis.—See Jell (1975).

\section{Pagetia fossula Resser, 1938a}

Figure 10

1938a Pagetia fossula Resser, p. 6, pl. 1, figs. 8-11.

1939b Pagetia maladensis Resser (part), p. 25, pl. 2, fig. 4 (part, pygidium in upper right corner), 5 (part, cranidia in upper left and upper center and pygidium at lower right). 
1966 Pagetia fossula; Rasetti, p. 507, pl. 59, figs. 22-28.

1966 Pagetia rugosa Rasetti, p. 509, pl. 60, figs. 1-7.

1968 Pagetia arenosa Fritz, p. 189, pl. 43, figs. 10, 11.

1979 Pagetia rugosa; Palmer and Halley, p. 77, pl. 12, figs. 9, 13.

1979 Pagetia sp., Palmer and Halley, p. 77, pl. 12, figs. 10, 14.

2018 Pagetia fossula; Sundberg, p. 16, fig. 10.1-10.12.

2018 Pagetia rugosa; Sundberg, p. 16, fig. 10.13-10.19.

Lectotype.-Here designated, pygidium USNM 95026 from USNM loc. $37 \mathrm{n}$.

Paralectotypes.-Here designated, USNM 95026a-e from USNM loc. $37 \mathrm{n}$.

Occurrence.-Lakeview Limestone (Ptychagnostus praecurrens Zone), Pend Oreille Lake, Idaho. Upper Langston Formation at Two Mile Canyon, Idaho (Rasetti, 1966; Campbell, 1974). Pyramid Shale member (Mexicella mexicana Zone), Carrara Formation, Belted Range, Nevada (Palmer and Halley, 1979). Pioche Shale (Glossopleura walcotti Zone?), northern Egan Range, Nevada (Fritz, 1968). Emigrant Formation (Glossopleura walcotti/Ptychagnostus praecurrens Zone), Split Mountain, Nevada (Sundberg, 2018).

Remarks.-Sundberg (2018) discussed the co-occurrence of Pagetia fossula Resser, 1938a and P. rugosa Rasetti, 1966 from the Emigrant Formation and the difficulty of separating the cranidia of the two species based on the convexity of the fixigena. The cranidia from the Lakeview Limestone also show a gradation in the convexity of the fixigena; but in addition, the pygidial convexity and development of the pleural furrows used to separate the two species also show a gradational change. As a result, the two species are synonymized here. An interesting difference between the material reported here and Resser's type specimens from the Lakeview Limestone (Rasetti, 1966, pl. 59, figs. 22-28) is the absence of the larger granules on the pleural bands of the pygidium, although one specimen (Rasetti, 1966, pl. 59, fig. 28) appears to also lack these granules.

?Order Corynexochida Kobayashi, 1935

Remarks.-Considering Corynexochida as a monophyletic group may be in error, and this taxon is probably polyphyletic, as suggested by Robison and Babcock (2011) and Sundberg (2014).

Family Dolichometopidae Walcott, 1916b Genus Athabaskia Raymond, 1928

Type species.-Athabaskia ostheimeri Raymond, 1928, from "Middle Cambrian strata at the Columbia Glacier at the head of the Athabaska River, in Alberta..." (Raymond, 1928, p. 312), by original designation.

Diagnosis._-See Lochman (1952).

Athabaskia minor (Resser, 1938a)

Figure 11 1938a Clavaspidella minor Resser, 1938a, p. 9, pl. 1, figs. 45, 46, 48, 49; non fig. 47 (= Elrathina idahoensis [Resser, 1938a]).

1952 Athabaskia minor; Lochman, p. 130, pl. 31, figs. 1-3.

Holotype.-Cranidium USNM 95039 from USNM loc. 37n.

Paratypes.-Specimens USNM 95039a-c from USNM loc. 37n. Also included by Resser (1938a, pl. 1, fig. 47) is a librigena USNM 95039d, which belongs to Elrathina idahoensis.

Occurrence.-Lakeview Limestone (Ptychagnostus praecurrens Zone), Pend Oreille Lake, Idaho (Resser, 1938a, 1939a). Arrojos Formation (Lochman, 1952, p. 131; Glossopleura walcotti Zone) or basal Tren Formation (Cooper and Arellano, 1952, p. 19), Arrojos Hills, Sonora, Mexico.

Remarks.-Resser (1938a) assigned a single external mold to the species, which clearly belongs to Elrathina idahoensis based on its small palpebral lobe suture, overall suture outline and short genal spine (Fig. 11.5). Lochman (1952, p. 130131) reassigned the species to Athabaskia and adequately redescribed the species based on the type specimens. She also reported the species from Sonora, Mexico, locality $800 \mathrm{~g}$, which she placed in the Arrojos Formation, but which Cooper and Arellano (1952, p. 19) placed in the Tren Formation. Figured herein are additional specimens, including larger cranidia and pygidia.

Athabaskia sp. indet. Figure 12

Occurrence.-Lakeview Limestone (Ptychagnostus praecurrens Zone), Pend Oreille Lake, Idaho.

Remarks. - Two cranidia occur stratigraphically above A. minor that are very similar except that they have occipital spines. No pygidia belonging to the genus were found, thus the taxonomic placement of the taxon is left open.

Dolichometopid hypostome indet. Figure 13.1-13.3

Remarks. - Several rostral plates/hypostomes were found in almost all horizons. Given that none of the specimens is directly associated (articulated) with cranidia, their specific affiliation cannot be assessed and they are left in open nomenclature. The characteristics of these specimens suggest that they belong to Dolichometopidae, being similar to hypostomes of Wenchemnia Resser, 1951 (see Sundberg, 1994). Athabaskia minor is the only species of this family found in the area studied. Whereas the cranidia of this species do attain the size to accommodate the hypostome, this species is relatively rare in the samples and cannot be definitely assigned to the hypostome. In addition, the hypostomes are also similar to Parkaspis Rasetti, 1951 (see Sundberg, 1994), which is assigned to Zacanthoididae (Sundberg, 1994). This family is only represented by Zacanthoides sampsoni Resser, 1938a in 

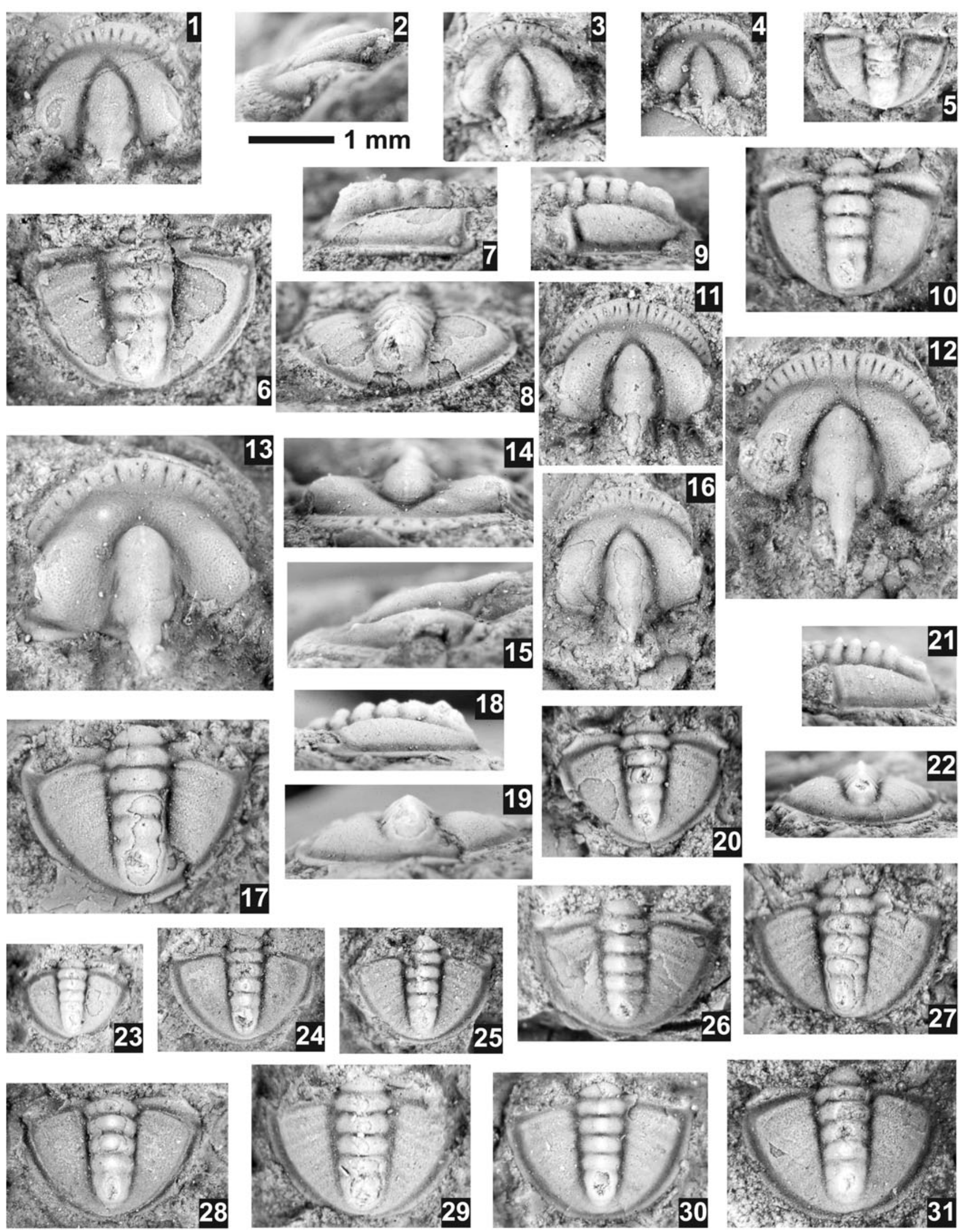
Figure 10. Pagetia fossula Resser, 1938a from the Ptychagnostus praecurrens Zone, Lakeview Limestone, Pend Oreille Lake, Idaho. (1-10) Resser's type collection from USNM loc. 37n. (1, 2) Testate paralectotype cranidium USNM 95026b, dorsal and lateral views; (3) exfoliated paralectotype cranidium USNM 95026e; (4) exfoliated paralectotype cranidium 95026b; (5) partially exfoliated paralectotype pygidium USNM 95026d; (6-8) mostly exfoliated lectotype pygidium USNM 95026, dorsal, lateral, and posterior views; $(\mathbf{9}, \mathbf{1 0})$ mostly testate paralectotype pygidium USNM 95026c, lateral and dorsal views. (11-31) Specimens collected in this study. (11) Testate cranidium USNM 724125 (USNM loc. 44282); (12) exfoliated cranidium USNM 724126 (USNM loc. 44280 ) showing longer occipital spine; (13-15) testate cranidium USNM 724128 (USNM loc. 44280), dorsal, anterior, and lateral views; (16) mostly testate cranidium USNM 724124 (USNM loc. 44282); (17-19) mostly testate pygidium USNM 724129 (USNM loc. 44280), dorsal, lateral, and posterior views; (20-22) mostly testate pygidium USNM 724132 (USNM loc. 44280), dorsal, lateral, and posterior views; (23) testate pygidium USNM 724133 (USNM loc. 44280); (24) exfoliated pygidium USNM 724123 (USNM loc. 44282); (25) exfoliated pygidium USNM 724120 (USNM loc. 44282); (26) partially testate pygidium USNM 724131 (USNM loc. 44280); (27) mostly testate pygidium USNM 724134 (USNM loc. 44280); (28) mostly exfoliated pygidium USNM 724122 (USNM loc. 44282); (29) mostly testate pygidium USNM 724127 (USNM loc. 44280); (30) mostly exfoliated pygidium USNM 724130 (USNM loc. 44280); (31) mostly testate pygidium USNM 724121 (USNM loc. 44282).
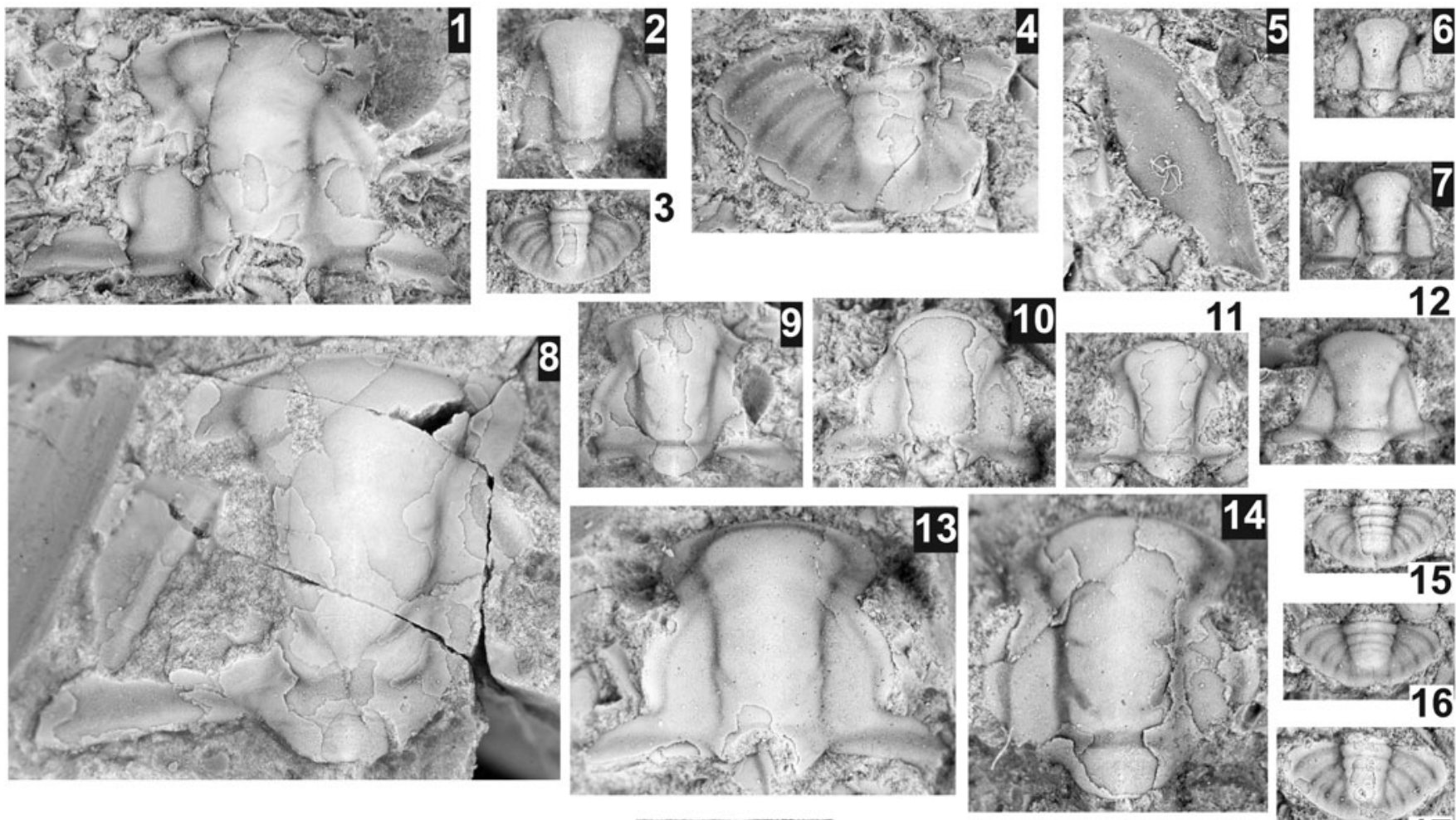

11
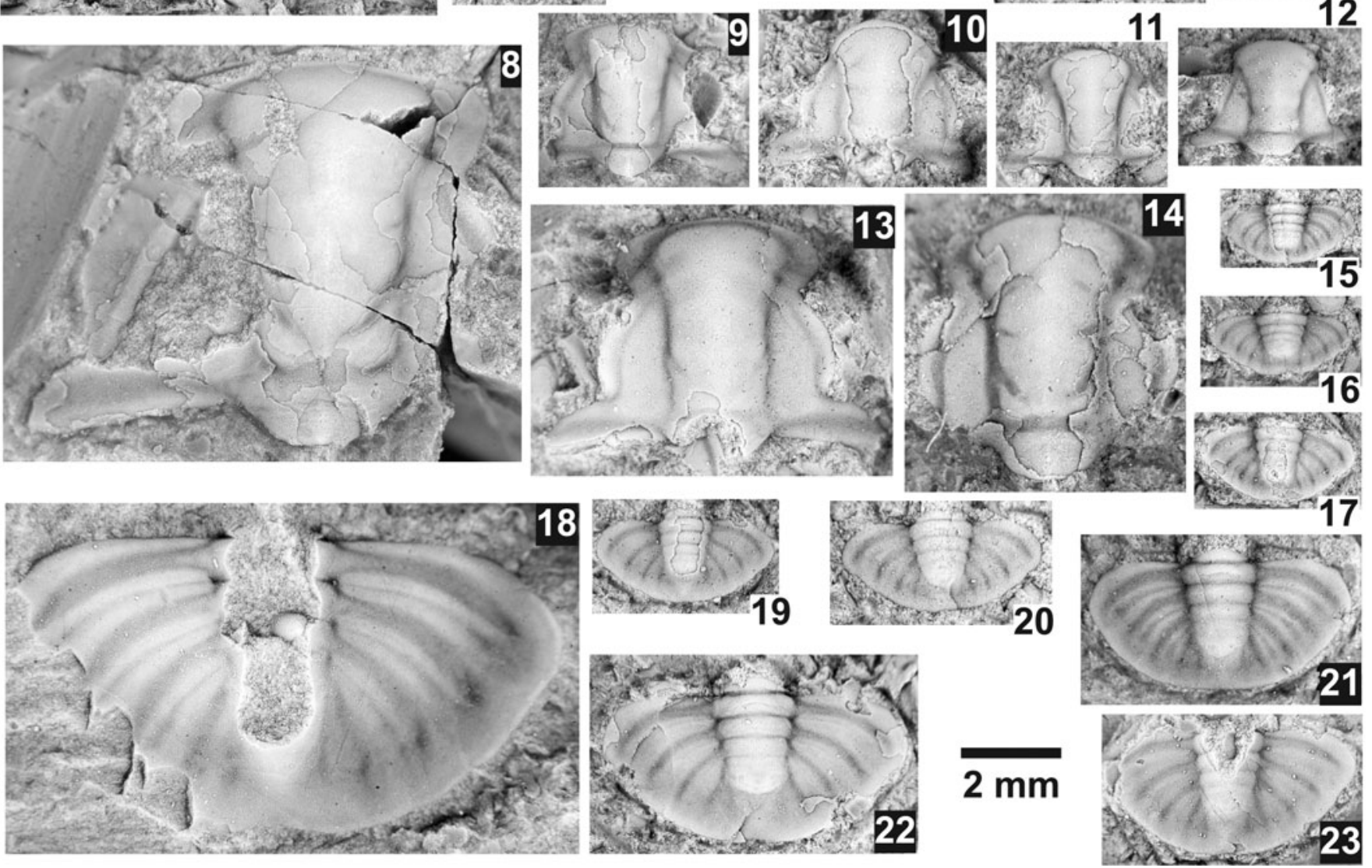

Figure 11. Athabaskia minor (Resser, 1938a) from the Ptychagnostus praecurrens Zone, Lakeview Limestone, Pend Oreille Lake, Idaho. (1-5) Resser's type specimens from USNM loc. 37n. (1) Mostly exfoliated, crushed holotype cranidium USNM 95039; (2) mostly testate paratype cranidium USNM 95039c; (3) mostly testate paratype pygidium USNM 95039b; (4) mostly testate paratype pygidium USNM 95039a; (5) internal mold of paratype librigena USNM 95039d, assigned to the species, but actually belonging to Elrathina idahoensis (Resser, 1938a). (6-23) Specimens collected in this study. (6) Small meraspid, exfoliated cranidium USNM 723993 (USNM loc. 44279); (7) small meraspid, mostly exfoliated cranidium USNM 723983 (USNM loc. 44280); (8) mostly exfoliated, damaged, large cranidium USNM 723996 (USNM loc. 44279); (9) mostly testate cranidium USNM 723994 (USNM loc. 44279); (10) mostly testate cranidium USNM 723992 (USNM loc. 44279); (11) mostly testate cranidium USNM 723987 (USNM loc. 44282); (12) mostly testate cranidium USNM 723980 (USNM loc. 44280 ); (13) mostly exfoliated, large cranidium USNM 724203 (USNM loc. 44279); (14) mostly exfoliated, large cranidium USNM 723982 (USNM loc. 44280); (15) mostly testate, small pygidium USNM 723988 (USNM loc. 44282); (16) mostly testate, small pygidium USNM 723985 (USNM loc. 44280); (17) mostly testate, small pygidium USNM 723986 (USNM loc. 44282); (18) exfoliated, large, partial pygidium USNM 723995 (USNM loc. 44279); (19) mostly testate pygidium USNM 723990 (USNM loc. 44282); (20) mostly testate pygidium USNM 723989 (USNM loc. 44282); (21) exfoliated pygidium USNM 723984 (USNM loc 44280); (22) exfoliated pygidium USNM 723981 (USNM loc. 44280); (23) exfoliated pygidium USNM 723991 (USNM loc. 44282). 

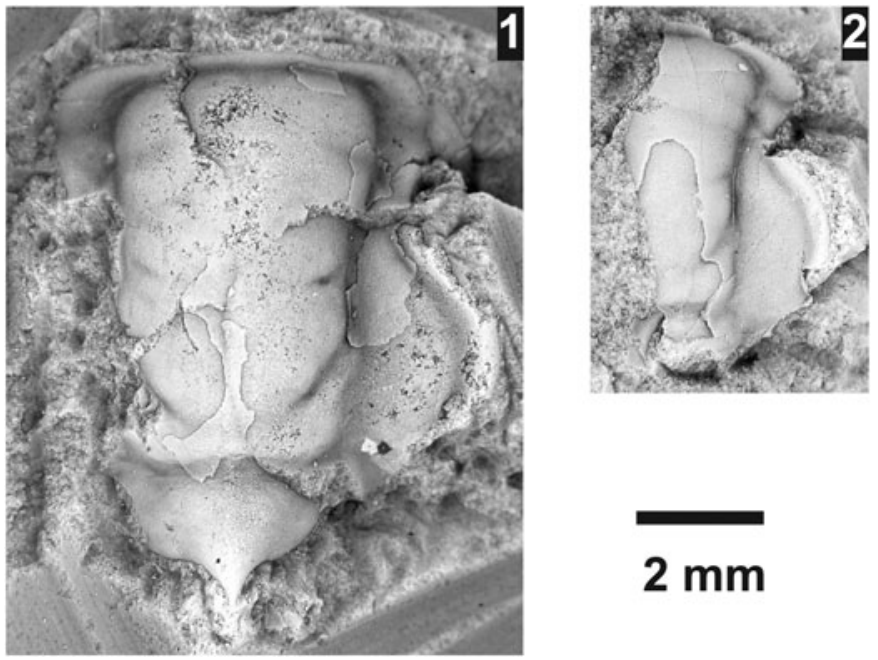

Figure 12. Athabaskia sp. from the Ptychagnostus praecurrens Zone, Lakeview Limestone, Pend Oreille Lake, Idaho, (USNM loc. 44283). (1) Mostly testate, partial cranidium USNM 723998; (2) partially testate, partial cranidium USNM 723997.

the Lakeview Limestone, a species that does not attain the cranidial size to accommodate the largest hypostome found.

Family Dorypygidae Kobayashi, 1935

Genus Kootenia Walcott, 1889

Type species.-Bathyuriscus (Kootenia) dawsoni Walcott, 1889, from the Stephen Formation, Mount Stephen, British Columbia, by original designation.

Diagnosis._-See Sundberg (1994).

Kootenia spp.

Figure 14
Remarks.-Over 100 species of Kootenia are named (see Palmer and Halley, 1979; Sundberg, 1994) and the group is in need of revision. One of the key characteristics is the features of the pygidia, especially the number of pygidial spine pairs. Resser (1939b) named 12 species of Kootenia from the age-equivalent Ptarmigania strata (= Spence Shale, Langston Formation) of northern Utah. These species have a range in pygidial spines from five to seven pairs. The pygidia from the Lakeview Limestone have five pairs of spines that curve upward. A single specimen (Fig. 14.9) has only four pairs of spines, lacking the terminal two smaller spines. Of Resser's (1939b) 12 species, five have five pairs of spines, $K$. convoluta, $K$. maladensis, $K$. granulosa, $K$. bearensis, and $K$. pectenoides. Of these, the most similar to the Lakeview Limestone specimens is $K$. bearensis, which is only known from pygidia. All of the species named by Resser (1939b) that are known from cranidia as well have strongly inflated glabella and, in larger specimens, suboval shapes. This is in sharp contrast to the specimens from the Lakeview Limestone, which have lower inflation of the glabella (Fig. 14.2) and a more expanding glabella (Fig. 14.1, 14.4, 14.6). A single large cranidium (Fig. 14.10) has a more oval glabella. As a result of the differences in pygidia spine pairs (four versus five) and glabella shape (suboval versus expanding), it is possible that two species are represented in the Lakeview Limestone. Given the potential mixture of two species and the specimens being generally incompletely preserved and very rare, the specimens from the Lakeview Limestone are left in open nomenclature.

Family Oryctocaridae Hupé, 1953

Subfamily Oryctocarinae Hupé, 1953

Genus Oryctocara Walcott, 1908

Type species.-Oryctocara geikiei Walcott, 1908, from the Spence Shale, Danish Flat, Idaho, by original designation.

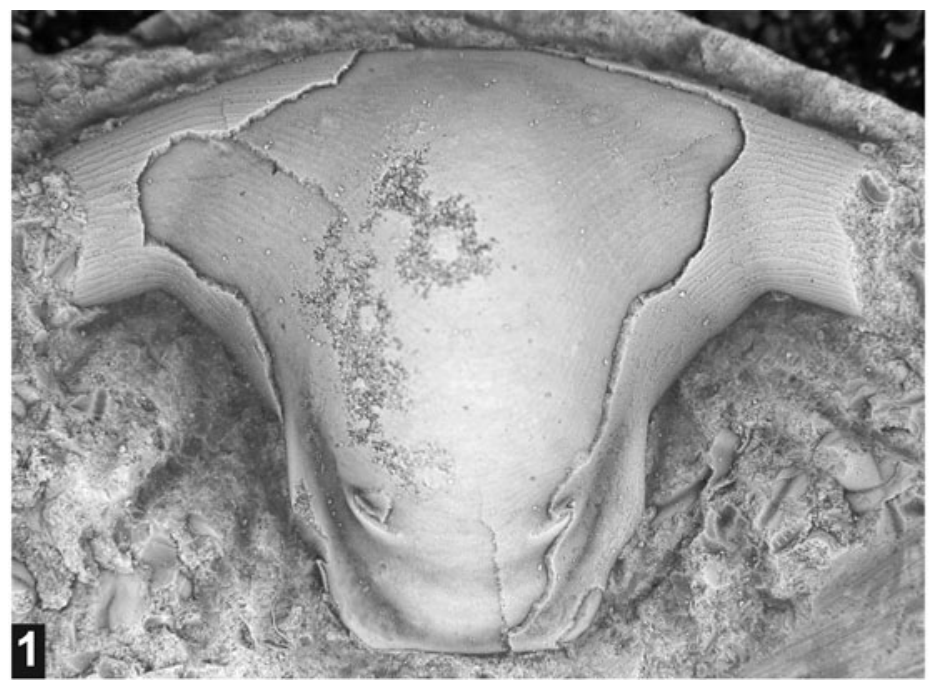

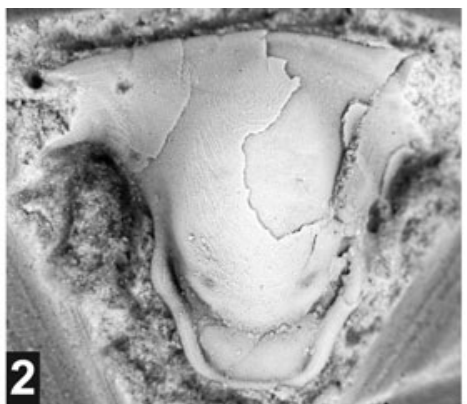
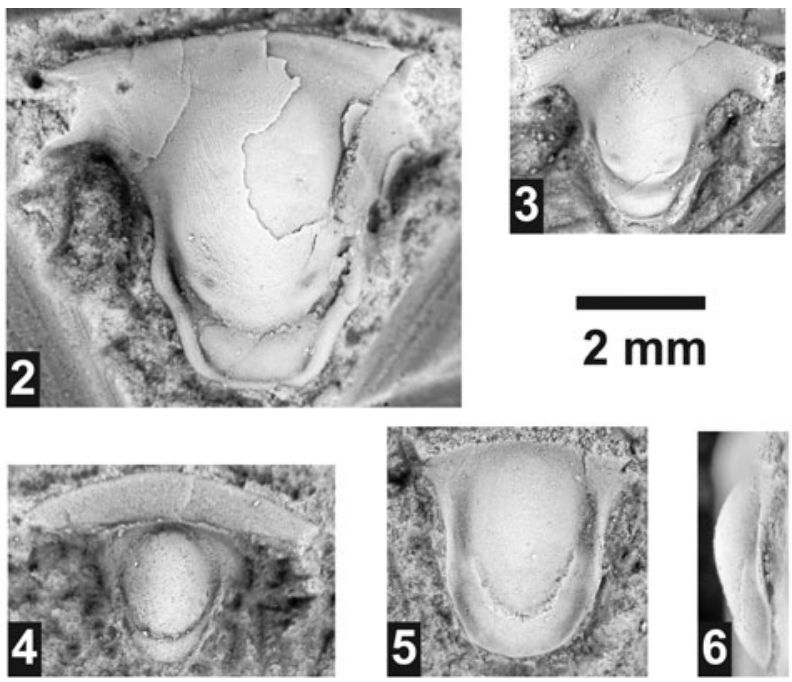

Figure 13. Hypostomes from the Ptychagnostus praecurrens Zone, Lakeview Limestone, Pend Oreille Lake, Idaho. (1-3) Dolichometopidae unidet.: (1) partially testate hypostome USNM 724198 (USNM loc. 44280); (2) mostly testate hypostome USNM 724199 (USNM loc. 44282); (3) exfoliated hypostome USNM 724200 (USNM loc. 44280). (4) Exfoliated oryctocephalid? hypostome USNM 724202 (USNM loc. 44283). (5, 6) Exfoliated ptychoparioid hypostome USNM 7242001 (USNM loc. 44280). 

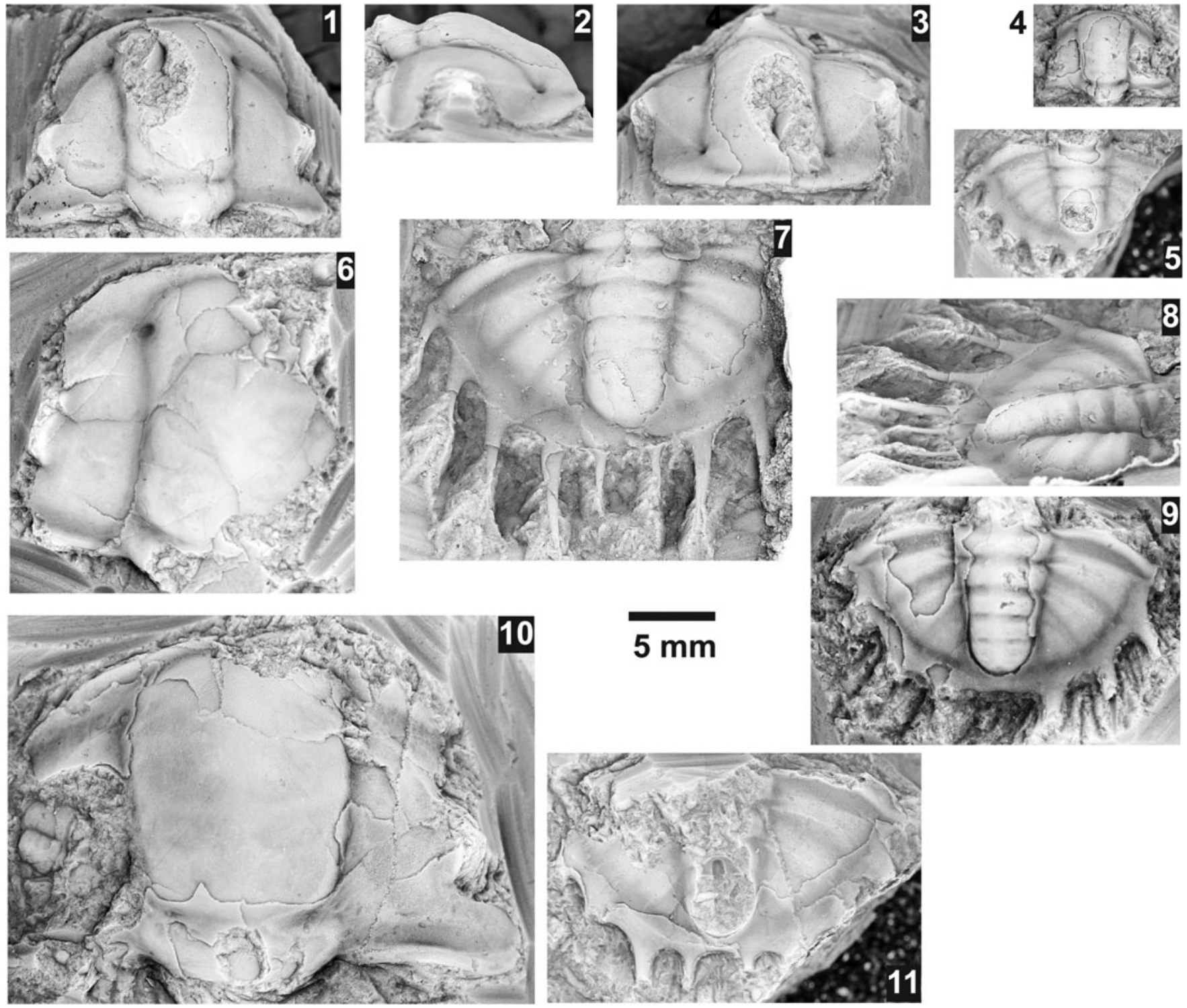

Figure 14. Kootenia spp. from the Ptychagnostus praecurrens Zone, Lakeview Limestone, Pend Oreille Lake, Idaho. (1-3) Mostly exfoliated cranidium USNM 724056 (USNM loc. 44282), dorsal, lateral, and anterior views; (4) partially testate cranidium USNM 724051 (USNM loc. 44280); (5) mostly testate pygidium USNM 724052 (USNM loc. 44282); (6) exfoliated cranidium USNM 724055 (USNM loc. 44282); (7, 8) latex cast of partially testate pygidium USNM 724053 (USNM loc. 44282), dorsal and slightly oblique lateral views; (9) mostly testate pygidium USNM 724054 (USNM loc. 44279) with only four pairs of spines; (10) mostly exfoliated, damaged, large cranidium USNM 724057 (USNM loc. 44282); (11) mostly exfoliated, pygidium USNM 724050 (USNM loc. 44280 ).

Diagnosis.—See Whittington (1995).

Oryctocara geikiei Walcott, 1908 Figure 15

1908 Oryctocara geikiei Walcott, p. 23, pl. 1, figs. 9, 10.

1938a Oryctocephalus walcotti Resser, p. 9, pl. 1, fig. 22 (only).

1938a Utia curio Walcott; Resser, p. 9, pl. 1, fig. 21 (only).

1939a Oryctocara geikiei; Resser, p. 21, pl. 1, pl. 2, figs. 22, 23.

1995 Oryctocara geikiei; Whittington, p. 556, pl. 4, figs. 2-9.

2015 Oryctocara geikiei; Robison et al., fig. 122.

Lectotype.-Shield USNM 53426, 53428 (part, counterpart), Spence Shale, Spence Gulch, Idaho.
Paralectotype.-Pygidium USNM 53427, Spence Shale, Spence Gulch, Idaho.

Occurrence.-Lakeview Limestone (Ptychagnostus praecurrens Zone), Pend Oreille Lake, Idaho (Resser, 1938a, 1939a). Spence Shale (Glossopleura walcotti Zone), Liberty Canyon and Two Mile Canyon, Idaho (Walcott, 1908; Campbell, 1974; Whittington, 1995) and Wellsville Mountains, Utah (Campbell, 1974; Robison et al., 2015). Stephen Formation (Glossopleura walcotti Zone), Mt. Stephen, Canada (Whittington, 1995).

Remarks.-Whittington (1995) provided an extensive description of Oryctocara geikiei as well as assigning a lectotype specimen. Resser (1938a, pl. 1, fig. 22) misidentified 

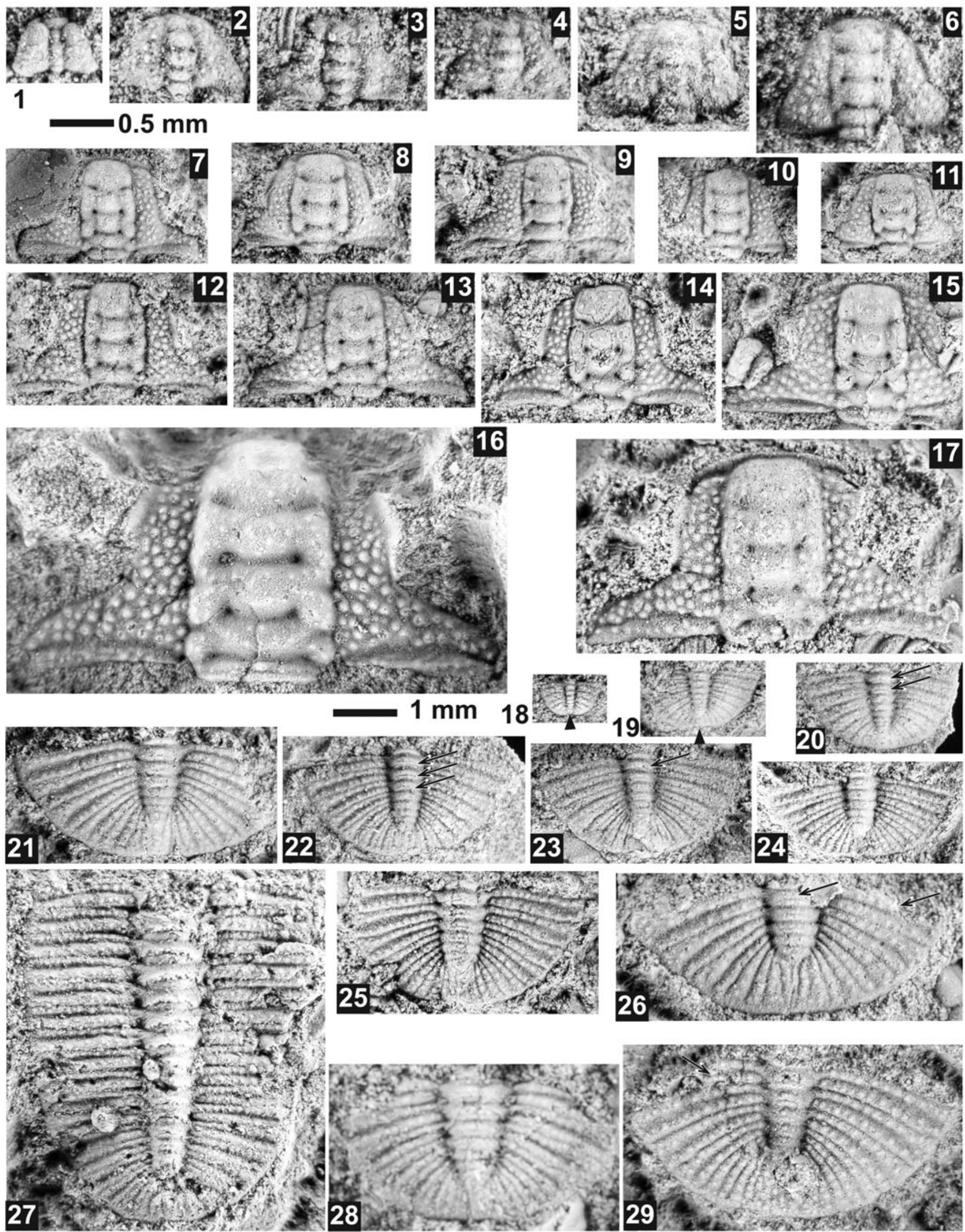
Figure 15. Oryctocara geikiei Walcott, 1908, from the Ptychagnostus praecurrens Zone, Lakeview Limestone, Pend Oreille Lake, Idaho. All specimens are from USNM loc. 44279, unless otherwise mentioned; (1-6) use $0.5 \mathrm{~mm}$ scale bar. Black triangle $(\mathbf{1 8}, \mathbf{1 9})$ marks indentation of posterior margin of the pygidium; arrows mark the exposure of the articulating ring(s) or broken pleural of the "thorax" (see text). (1) Small meraspid cranidium USNM 724080 questionably assigned to the species; (2) meraspid cranidium USNM 724078; (3) meraspid cranidium USNM 724077; (4) meraspid cranidium USNM 724079; (5) meraspid cranidium USNM 724062;. (6) meraspid cranidium USNM 724064; (7) cranidium USNM 724065; (8) cranidium USNM 724075; (9) cranidium USNM 724073; (10) cranidium USNM 724071; (11) cranidium USNM 724068; (12) cranidium USNM 724082; (13) cranidium USNM 724061; (14) cranidium USNM 724072; (15) cranidium USNM 724069; (16) damaged large cranidium USNM 724074; (17) cranidium USNM 724058; (18) small meraspid pygidium USNM 724063; (19) meraspid pygidium USNM 724083; (20) meraspid pygidium USNM 724085; (21) pygidium USNM 724070; (22) pygidium USNM 724076; (23) pygidium USNM 724066; (24) pygidium USNM 724060; (25) pygidium USNM 724059; (26) pygidium USNM 724084; (27) thorax and pygidium USNM 724067; (28) pygidium USNM 95041b (USNM loc. 37n); (29) pygidium USNM 724081.

the cranidium of $O$. geikiei as that of Oryctocephalites walcotti (Resser, 1938a; paratype USNM 95038a) and the pygidium (p. 1, fig. 21, USNM 95041b) as that of Utia curio Walcott, 1924. Whittington (1995, pl. 4, figs. 2, 4) reassigned and re-illustrated the cranidium USNM 95041a and questionably the pygidium to $O$. geikiei (Fig. 15.28); however, additional pygidia from this study show that the pygidium belongs to $O$. geikiei.

Whittington (1995) reported 11-12 thoracic segments and six (?) pygidial axial rings and a terminal piece. None of the specimens from the Lakeview Limestone is known from completely articulated shields. The single specimen of articulated thorax and pygidium has 10 thoracic segments. Isolated pygidia have potentially a fused thoracic segment based on fragmentation (Fig. 15.26, 15.29) and exposure of the articulating ring(s) (Fig. 15.20-15.23, 15.26). Complicating this situation is that the pygidial axial rings commonly have a shallow furrow separating the anterior and posterior portion of each ring. These features are also seen in species of Arthricocephalus Bergeron, 1899, Oryctocarella Tomashpolskaya and Karpinski, 1961, and Ovatoryctocara Chernysheva, 1962 (see Geyer and Peel, 2011; Peng et al., 2017, which is referred to as a partially released segment of the transitory pygidium). As a result, pygidia range from three to seven (Fig. 16) axial rings plus a terminal piece, unless the "thoracic segment" is fused to the pygidium, then the range would be four to eight axial rings plus a terminal piece. The broad distribution of the number of axial rings across a range of sizes suggests that axial ring count is

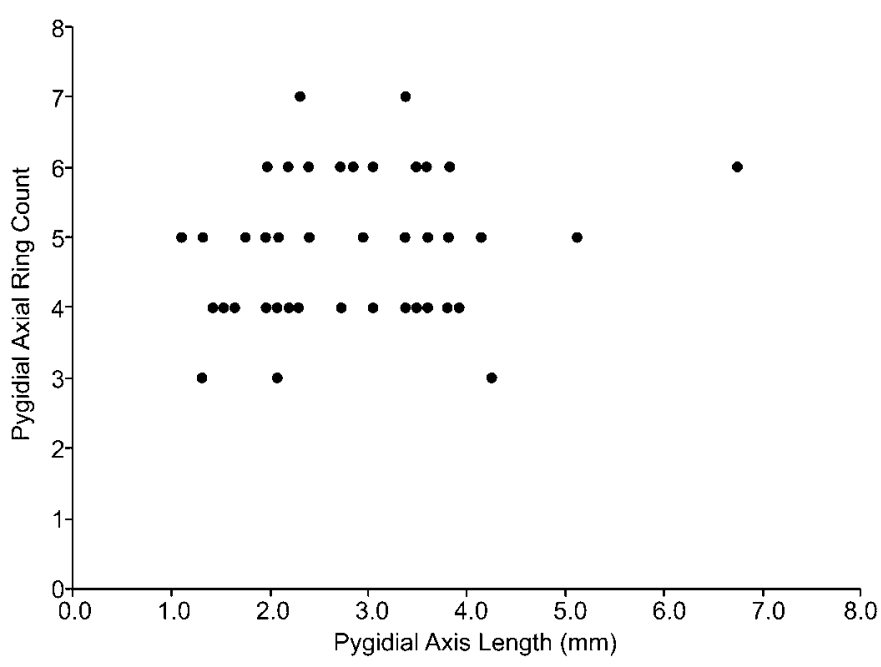

Figure 16. Pygidial axial ring count (not including terminal piece) versus the axial length in Oryctocara geikiei Walcott, 1908, illustrating the amount of ring variation across a range of sizes. All specimens $(\mathrm{N}=49)$ are from USNM loc. 44279. not fixed in meraspids or holaspids and cannot be used as a specific or generic diagnosis.

The ontogeny of $O$. geikiei from the Lakeview Limestone is represented by disarticulated material, thus meraspid degrees cannot be assigned, nor can the transition between meraspids and holaspids. In general, the smallest meraspid cranidium questionably assigned to this species (Fig. 15.1) has a narrow, parallel-sided glabella with a triangular expanding frontal lobe, faint transglabellar furrows, and a proparian suture similar to Ovatoryctocara granulata Chernysheva, 1962 and O. yaxiensis Yuan et al., 2009 (Geyer and Peel, 2011, figs.16G, 16U, 17H). Slightly larger meraspids (Fig. 15.2-15.6) have granules, expanding medial portion of the glabella, more parallel-sided frontal lobe, well-developed transglabellar furrows, some development of the longitudinal furrows and moderately to strongly developed glabellar pits, and palpebral lobes angled adaxially from the glabella forming a wider, posterior portion of the palpebral area of the fixigena. Larger cranidia (Fig. 15.7-15.17) have well-developed anterior and posterior borders, more parallel-sided glabella with well-developed S1 and S2 transglabellar furrows, weak S3 transglabellar furrow, well-developed glabellar pits, S3 pit slit-shaped, lateral glabellar furrows connecting to glabellar furrows at the $\mathrm{S} 1$ and $\mathrm{S} 3$ positions, palpebral lobes nearly parallel to glabella forming a narrow palpebral area of the fixigena, and a gonatoparian facial suture.

Smallest pygidia have a medial inbend on the posterior margin, pygidial axis that reaches the posterior margin, welldeveloped plural furrows, weakly developed interpleural furrows (Fig. 15.18). A slightly larger specimen (Fig. 15.19) has scattered granules on the pleural field, slight medial indentation of the posterior margin, pygidial axis that does not reach the posterior margin, and well-developed plural and inter pleural furrows. Larger specimens (Fig. 15.20-15.29) have relatively shorter axes, and a smoothly rounded posterior margin.

\section{Genus Thoracocare Robison and Campbell, 1974}

Type species.—Vistoia? minuta Resser, 1939a, from the Spence Shale, Bear River Range, Idaho.

Diagnosis._-See Robison and Campbell (1974).

Remarks.-Robison and Campbell (1974) tentatively assigned Thoracocare to Oryctocephalidae based on features of the meraspides of Oryctocara. Sundberg (2018) supported this assignment.

Thoracocare minuta (Resser, 1939a)

Figure 17 
1939a Vistoia? minuta Resser, p. 21, pl. 2, fig. 2; non pl. 2, fig. 1 (= Pentagnostus bonnerensis).

1974 Thoracocare minuta; Robison and Campbell, p. 274, figs. 1, 2B, 2C.

2015 Thoracocare minuta; Robison et al., fig. 139.

Holotype.-Pygidium USNM 188551 from USNM loc. 55c. Robison and Campbell (1974) list this locality as 96511, which is the original lot number for the type specimens.

Paratypes.-Two pygidia under USNM 96511 (original type lot) and pygidium USNM 188194 (originally part of type lot, figured by Robison and Campbell, 1974, fig 2.C) from USNM loc. $55 \mathrm{c}$.

Occurrence.-Lakeview Limestone (Ptychagnostus praecurrens Zone), Pend Oreille Lake, Idaho. Spence Shale (Glossopleura walcotti Zone), Bear River Range, Malad Range, and Oneida Narrows, Idaho, Wasatch Mountains, Utah (Campbell, 1974; Robison and Campbell, 1974).

Remarks.-The few cranidia and pygidia of Thoracocare minuta from the Lakeview Limestone are similar in size and morphology to the age-equivalent specimens from the Mexicella mexicana and Glossopleura walcotti zones, Spence Shale, Utah (Robison and Campbell, 1974). Sundberg (2018) discussed the differences between Robison and Campbell's (1974) specimens and T. cf. T. minuta from the Emigrant Formation, Nevada, which are larger and the differences may be the result ontogenetic changes.

Thoracocare idahoensis (Resser, 1939b) (see Robison and Campbell, 1974, for additional information), also from the Glossopleura walcotti Zone, Spence Shale, Utah, differs from the Lakeview Limestone specimens in having cranidium with effaced cranidial furrows and wider fixigenae and pygidia that have better defined pleural and interpleural furrows. Robison
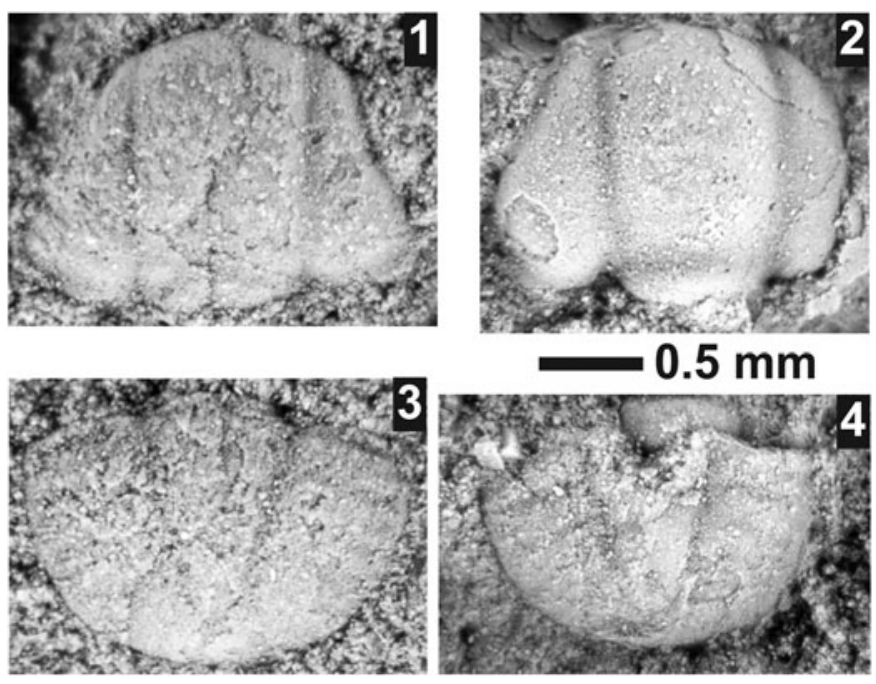

Figure 17. Thoracocare minuta (Resser, 1939b) from USNM loc. 44279, the Ptychagnostus praecurrens Zone, Lakeview Limestone, Pend Oreille Lake, Idaho. (1) Testate cranidium USNM 724157; (2) incomplete testate cranidium USNM 724158; (3) testate pygidium USNM 724160; (4) mostly testate, damaged pygidium USNM 724159. and Campbell (1974) distinguished the two species also by the length-to-width ratio of the pygidia; measurements from their illustrated specimens, however, do not support this distinction (see Sundberg, 2018).

Family Oryctocephalidae Beecher, 1897

Subfamily Lancastriinae Kobayashi, 1935

Oryctocephalites Resser, 1939b

Type species.-Oryctocephalites typicalis Resser, 1939b, from the Spence Shale, Wasatch Mountains, Idaho, by original designation.

Diagnosis._-See Sundberg (2014).

Oryctocephalites reynoldsi (Reed, 1899)

Figures 18, 19

1899 Oryctocephalus reynoldsi Reed, p. 359, text fig. (line drawing).

1908 Oryctocephalus reynoldsi; Walcott, pl. 3, fig. 1.

1938a Oryctocephalus walcotti Resser, p. 6, pl. 1, fig. 23; non pl. 1, fig. 22 (= Oryctocara geikiei).

1939a Oryctocephalus walcotti; Resser, p. 13, pl. 2, figs. 15-18.

1951 Oryctocephalus reynoldsi; Rasetti, p. 193, pl. 29, figs. 4, 5 .

non Oryctocephalus reynoldsi; Shergold, p. 18, pl. 3, figs. 1969 1-6.

1995 Oryctocephalus reynoldsi; Whittington, p. 548, pl. 1, figs. 1, 3-6.

2000 Oryctocephalites walcotti; Sundberg, figs. 4a, 6.

2015 Oryctocephalus walcotti; Robison et al., fig. 123.

Holotype.-Shield A1425 (Sedgwick Museum), Stephen Formation, Mt. Stephen, Canada.

Occurrence.-Lakeview Limestone (Ptychagnostus praecurrens Zone), Pend Oreille Lake, Idaho. Spence Shale, southern Idaho (Resser, 1939a) and Wellsville Mountains, Utah (Campbell, 1974; Robison et al., 2015). Stephen Formation (Glossopleura walcotti and Ehmaniella zones), Mt. Stephen, Canada (Whittington, 1995).

Remarks.-Oryctocephalus walcotti Resser, 1938a, O. reynoldsiformis (Lermontova, 1940), O. reynoldsi (Reed, 1899), and O. burgessensis (Resser, 1938b) form the crown group of the Oryctocephalites subclade (Sundberg, 2014, fig. 3). However, based on the new material from the Lakeview Limestone, Oryctocephalus walcotti is here reassigned to Oryctocephalites reynoldsi. This reassignment is based on: (1) cranidial features, including an expanding glabella, bluntly rounded frontal lobe, nearly straight and relatively flat anterior border, and relatively weak ocular ridges; (2) librigenal features, including flat lateral border, slightly advanced genal spine, long and relatively narrow genal spine; and (3) pygidial features, including five axial rings, six pygidial spines that are broad based but rapidly narrow to points, three uniform pairs of anterior spines, 

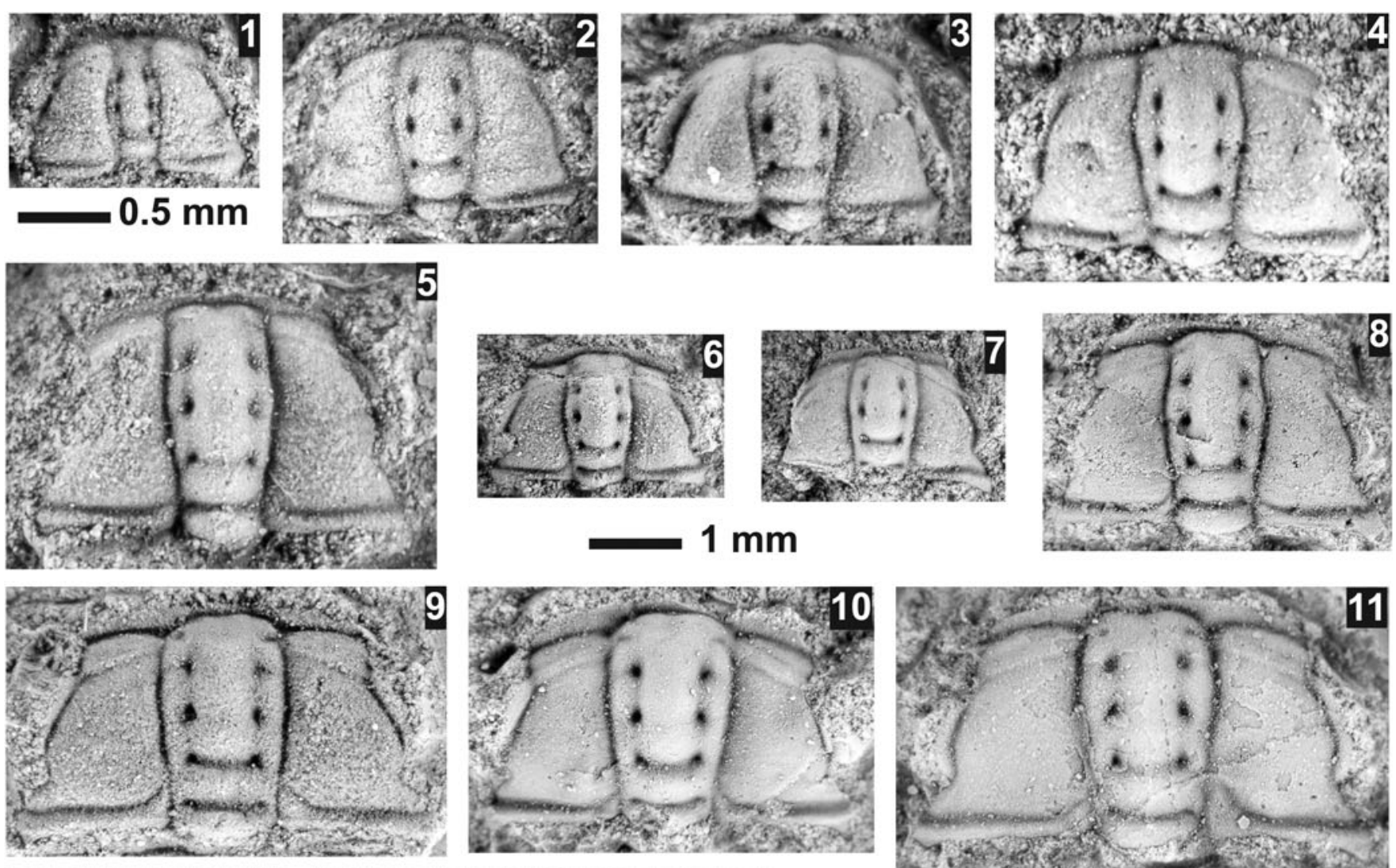
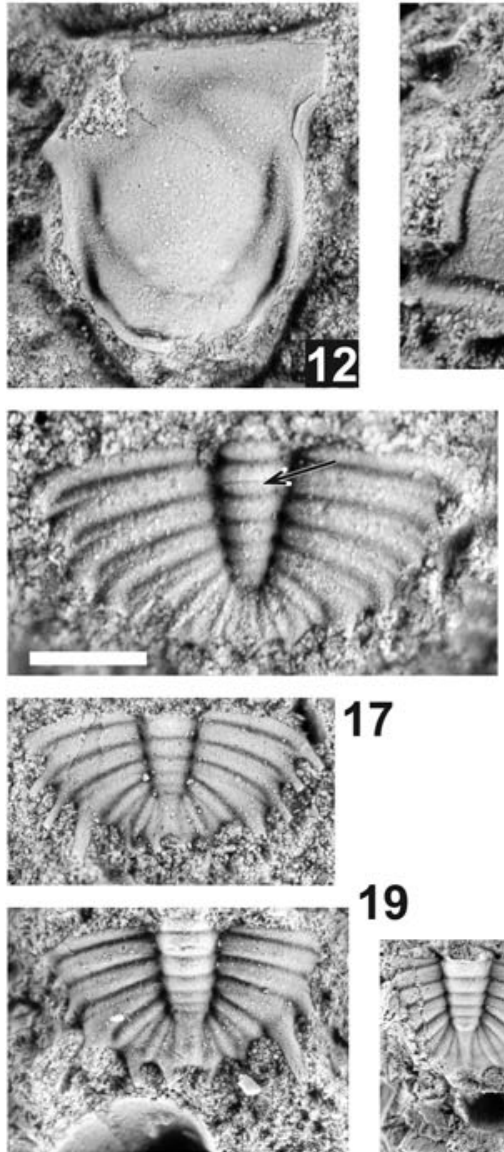
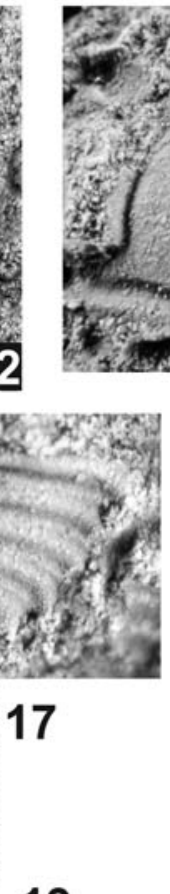

15

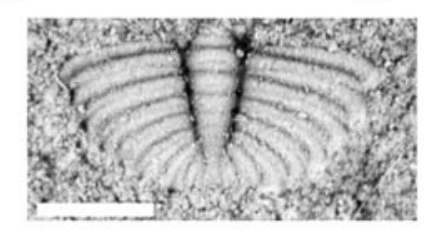

16

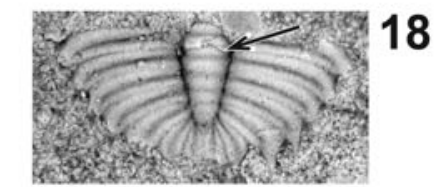

19

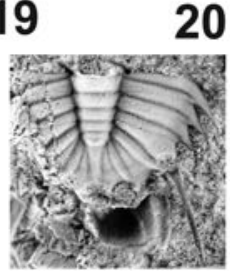

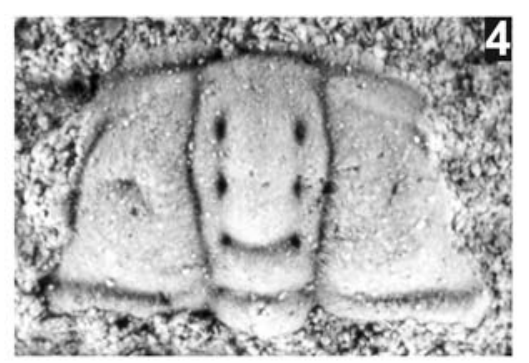

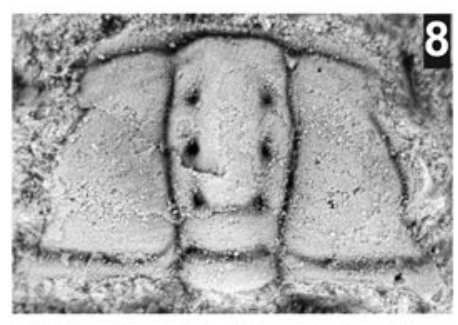


Figure 18. Oryctocephalites reynoldsi (Reed, 1899) from the Ptychagnostus praecurrens Zone, Lakeview Limestone, Pend Oreille Lake, Idaho. All specimens are from USNM loc. 44279; (1-5, 15, 16) use $0.5 \mathrm{~mm}$ scale bar. Arrows mark the exposure of the articulating ring(s). (1) Small meraspid cranidium USNM 724096; (2) meraspid cranidium USNM 724114; (3) meraspid cranidium USNM 724087; (4) meraspid cranidium USNM 724111; (5) meraspid cranidium USNM 724094; (6) cranidium USNM 724090; (7) cranidium USNM 724091; (8) cranidium USNM 724112; (9) cranidium USNM 724110; (10) cranidium USNM 724092; (11) cranidium USNM 724113; (12) hypostome USNM 724098; (13) cranidium USNM 724100; (14) cranidium USNM 724101; (15) small meraspid pygidium USNM 724088, white bar is $0.5 \mathrm{~mm}$; (16) small meraspid pygidium USNM 724116, white bar is $0.5 \mathrm{~mm}$; (17) pygidium USNM 724115; (18) pygidium USNM 724117; (19) pygidium USNM 724086; (20) pygidium USNM 724095; (21) pygidium USNM 724093; (22) pygidium USNM 724099.

macrospine that are relatively long, and two pairs of posterior spines that are shorter than the other pygidial spines, poorly developed interplural furrows in anterior segments, then well-defined furrows in posterior segment. These similarities are outlined here due to the Lakeview Limestone specimens, being preserved in limestone, providing less-compressed samples and the type and other specimens are from the Stephen Formation, which are very compressed.

Whittington (1995) redescribed the species based on the flattened specimens from the Burgess Shale. Slight modifications to the description include: the glabella expands from the occipital ring to the L3 position and then slightly narrows, faint S4 furrows are present in all size specimens, the anterior three pairs of pygidial spines and the macropleural spines dorsally flexed.

Sundberg (2000) discussed Oryctocephalites walcotti from the Spence Shale. These specimens are here assigned to $O$. reynoldsi.

Shergold (1969) reported $O$. reynoldsi from the Sandover Beds, Arthur Creek Beds, and Beetle Creek Formation, Australia, but these shale specimens differ in having cranidia with slightly narrower (tr.) fixigena (Fig. 20) and pygidia with welldeveloped interpleural furrows between the three anterior segments and broader pygidial spines in larger specimens. These features are similar to O. reynoldsiformis, particularly the higher stratigraphic position of the Siberian species (see below).

Lermontova (1940, p. 138) described Oryctocephalites reynoldsiformis from the Kuonamka Formation, Kounamkites Zone, as "resembles Oryctocephalus reynoldsi Reed but its glabella has only posterior pair of furrows connected by transversal furrow. There are longitudinal furrows between pits. Palpebral lobes longer, begin almost from occipital furrow" [translation provided by T. Pegel']. These differences between the two species are incorrect, both have only an S1 transglabellar furrow, the smaller specimens have longitudinal furrows between the pits, and the palpebral lobes are of equal length (exsag.) (Lermontova, 1940, pl. 42, figs. 2, 2a, 2b; Fig. 18.4, 18.10, 18.14). However, differences between $O$. reynoldsi and $O$. reynoldsiformis occur in the pygidium, which the latter has only two segments anterior of the macropleural spine that have well-defined interpleural furrows (Lermontova, 1940, pl. 42, figs. 2c-e). These differences are not the result of ontogeny; small pygidia of $O$. reynoldsi (Fig. 18.17-18.21) have three anterior pygidial segments with poorly defined interpleural furrows. Korovnikov and Shabanov (2008, pl. 3, figs. 5, 6) and Shabanov et al. (2008; same specimens) illustrated a well-preserved cranidium and pygidium of $O$. reynoldsiformis from stratigraphically lower Ovatoryctocara Zone of the Kuonomka Formation. In comparison to $O$. reynoldsi, the cranidium (pl. 3, fig. 5) has a more pronounced S1 transglabellar furrow and a more convex anterior border and the pygidium (pl. 3, fig. 6) has better defined interpleural furrows and only five pairs of marginal spines. Egorova et al. (1976) illustrated several specimens of $O$. reynoldsiformis from the Kounamkites Zone of the Kuonomka Formation. Several pygidia appear to be the same as the type specimens (Egorova et al., 1976, pl. 48, figs. 19, 21-23, pl. 49 , figs. 17, 18; most photographs are too small to see the necessary details). However, the specimen illustrated by Egorova et al. (1976, pl. 51, fig. 7, and possibly pl. 52, fig. 1) from an interval slightly higher in the section $(\sim 1 \mathrm{~m})$, clearly has three anterior segments similar to $O$. reynoldsi, but still has well-defined interpleural lobes.

\section{Oryctocephalid? hypostome undet.} Figure 13.4

Remarks.-A partly articulated rostral plate and hypostome was found occurring with $O$. reynoldsi at USNM loc. 44283. It is similar to the rostral plate and hypostome assigned to the species (Fig. 18.12), but differs in having a longer rostral plate, more oval median body, shallower macula, and possibly a weaker suture between the two sclerites. There are no other oryctocephalids know from this locality, so the nomenclature is left open.

\section{Family Zacanthoididae Swinnerton, 1915 Genus Zacanthoides Walcott, 1888}

Type species.—Embolimus spinosus Rominger, 1887, from the Stephen Formation, Mount Stephen, British Columbia.

\section{Diagnosis.—See Sundberg (1994). \\ Zacanthoides sampsoni Resser, 1938a Figure 21}

1938a Zacanthoides sampsoni Resser, p. 6, pl. 1, figs. 16, 17.

Holotype.—Shield USNM 95042 from USNM loc. 37n.

Paratypes.-Specimens USNM 95042a-c from USNM loc. $37 n$.

Diagnosis. - Cranidium having strongly divergent anterior facial sutures ranging $\sim 70^{\circ}$ to an exsagittal line, frontal area lacking plectrum, fine granular ornamentation, glabellar expansion of $\sim 125 \%$ of glabellar width, and fixigena $\sim 65 \%$ glabellar width. Thorax with eight segments. Pygidium rectangular, five pairs of spines, and moderately long pygidial spines.

Occurrence.-Lakeview Limestone (Ptychagnostus praecurrens Zone), Pend Oreille Lake, Idaho 

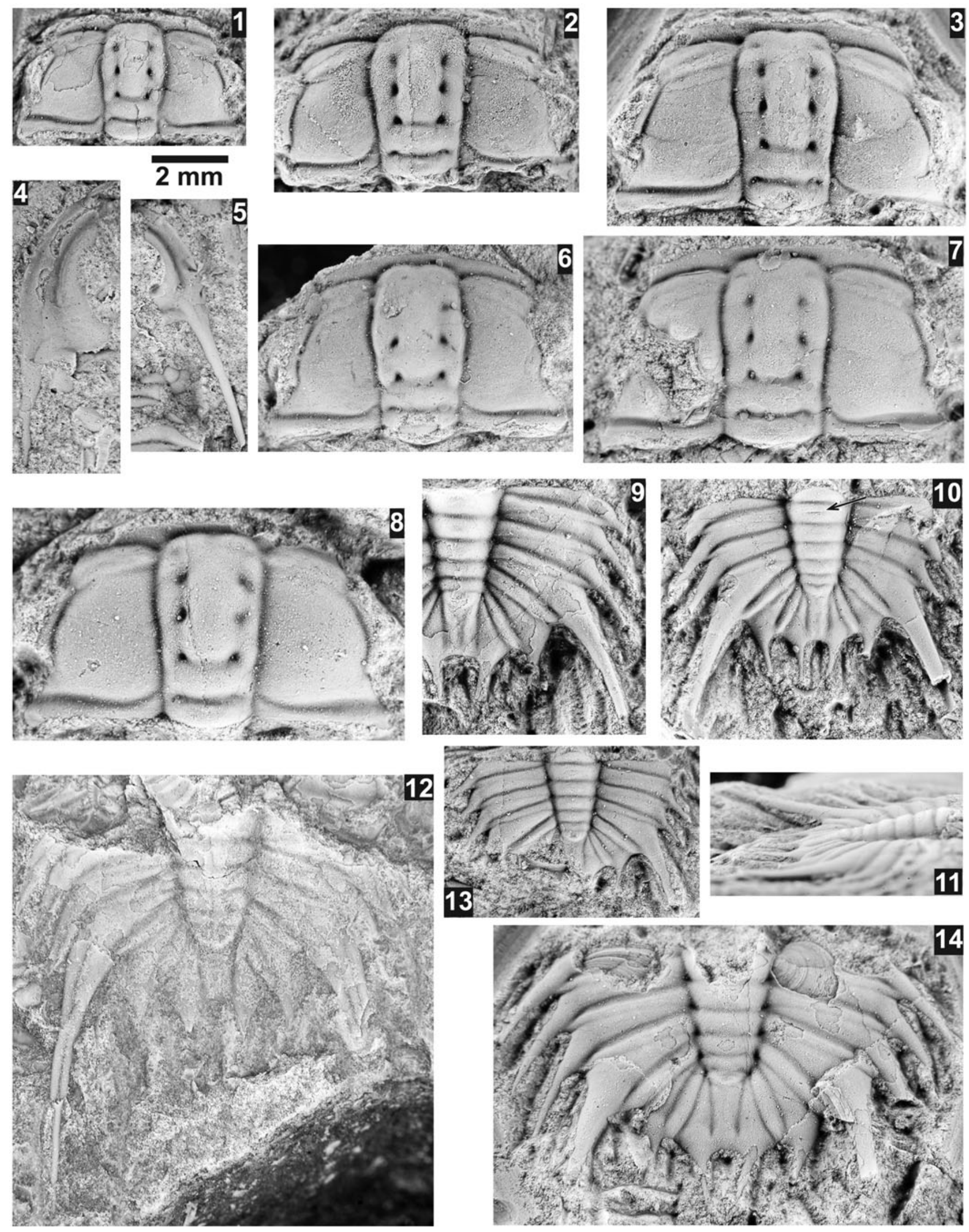
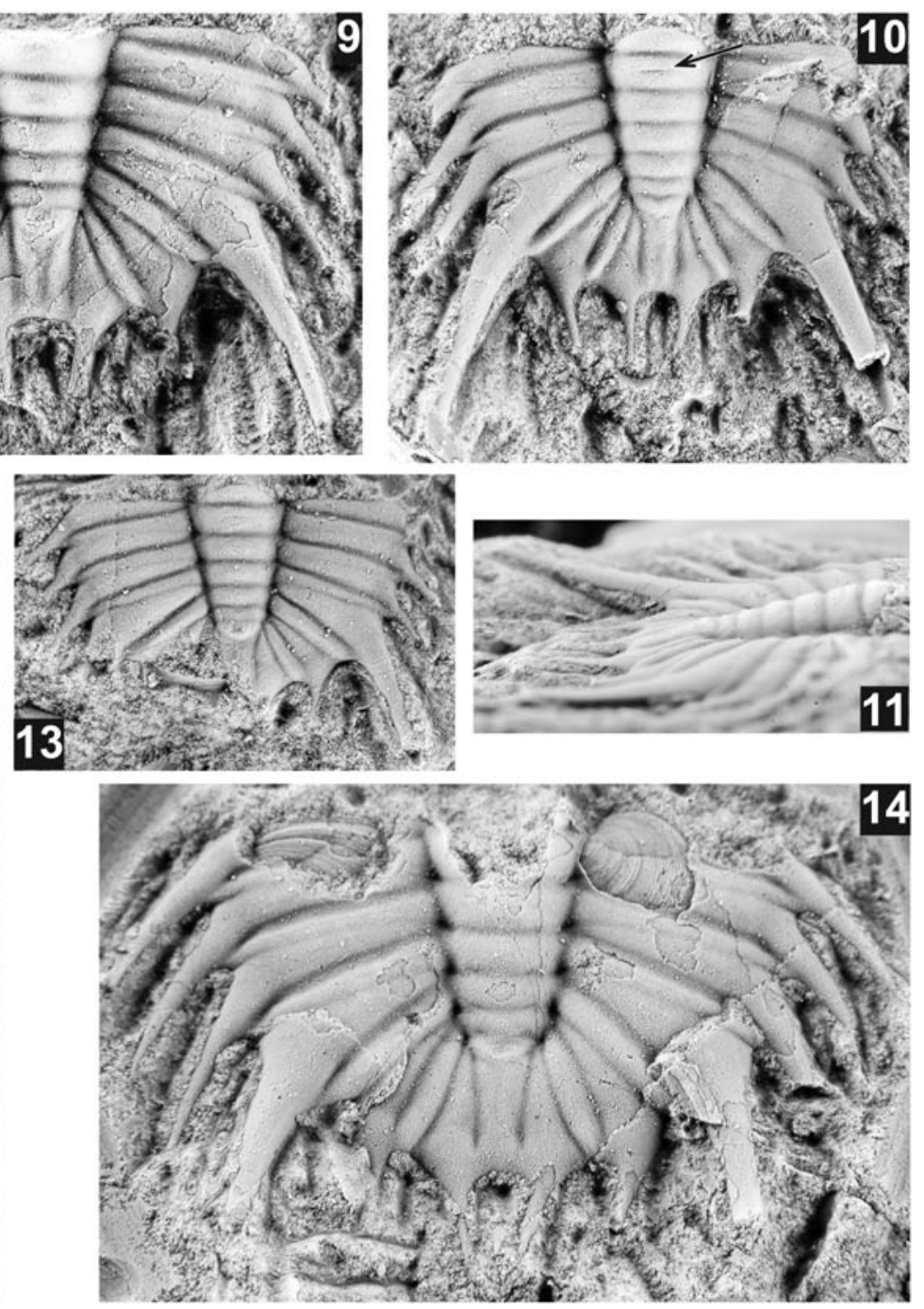
Figure 19. Oryctocephalites reynoldsi (Reed, 1899) from the Ptychagnostus praecurrens Zone, Lakeview Limestone, Pend Oreille Lake, Idaho. All specimens are from USNM loc. 44279, unless otherwise mentioned. Arrows mark the exposure of the articulating ring(s). (1) Cranidium USNM 724106; (2) cranidium USNM 724109; (3) cranidium USNM 724103; (4) latex cast of librigena USNM 724118; (5) latex cast of librigena USNM 724119; (6) cranidium USNM 724097; (7) cranidium USNM 724089; (8) cranidium USNM 724102; (9) pygidium USNM 724108; (10, 11) pygidium USNM 724104, dorsal and slightly oblique lateral views; (12) holotype pygidium USNM 95038 (USNM loc. 37n); (13) pygidium USNM 724105; (14) pygidium USNM 724107.

Description.-Cranidium $\quad(\mathrm{N}=20) \quad 1.9-7.6 \quad \mathrm{~mm} \quad$ long; rectangular, excluding posterior portion of fixigena, length 61 $\pm 3 \%$ width; high convexity (sag. and trans.); anterior margin evenly curved, width $64 \pm 4 \%$ cranidial width; posterior margin, excluding occipital ring, nearly straight, posterior area of fixigena bowed posteriorly. Facial suture's anterior branch strongly divergent, $70 \pm 4^{\circ}$ to exsagittal line; posterior branch very strongly divergent, $98 \pm 5^{\circ}$ posteriorly to exsagittal line. Glabellar length $85 \pm 2 \%$ and width $38 \pm 3 \%$ cranidial length; width $23 \pm 1 \%$ cranidial width; expanding anteriorly, width at frontal lobe $125 \pm 9 \%$ glabellar width $\left(\mathrm{K}_{2}\right)$; moderate convexity (sag. and trans.); frontal lobe rounded, sometimes with slight medial sulcus. Axial furrows moderately deep, deeper adjacent to L2, shallow with intersection of eye ridge; preglabellar furrow shallow; lateral glabellar furrows moderately deep, S1 directed posterolaterally furrows, sometimes bifurcated, S2 commonly developed as pit isolated from the axial furrow in medium to larger specimens, S3 directed anteriolaterally, shallow isolated from axial furrows in larger specimens, S4 directed anteriolaterally, shallow. Occipital ring length $21 \pm 2 \%$ glabellar length, slightly elevated above glabella, moderate convexity (sag. and tr.); short occipital spine; S0 curved

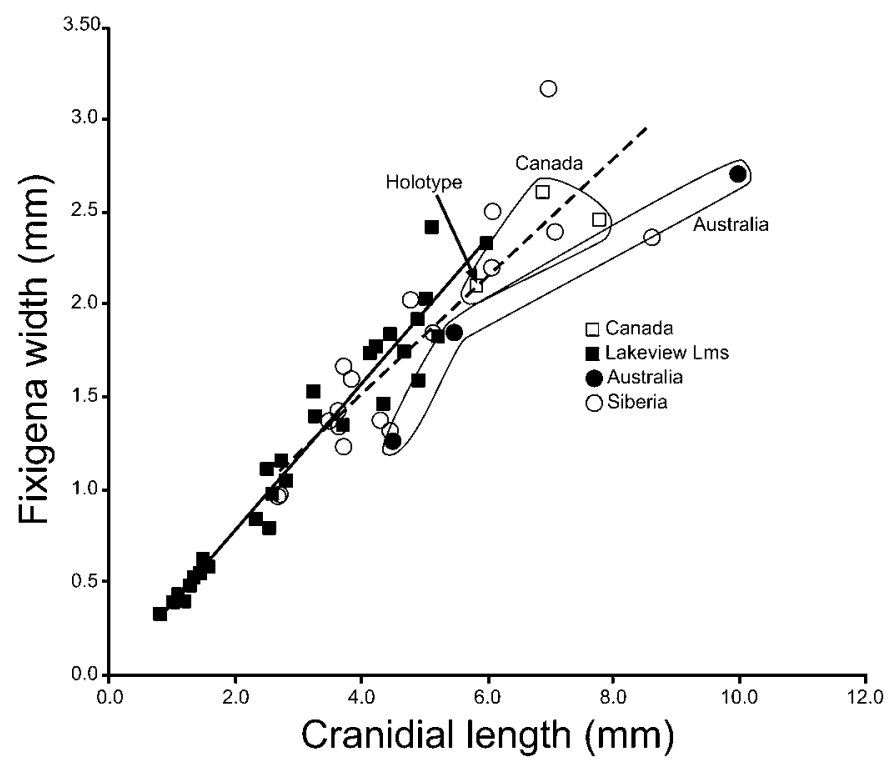

Figure 20. Bivariate plot of Oryctocephalites reynoldsi (Reed, 1899) from the Lakeview Limestone (Idaho, a) and Stephens Formation (Canada, $\square$ ), "O. reynoldsi" of Shergold (1969; Australia, ๑) and O. reynoldsiforms (Lermontova, 1940; Siberia, O). Trend lines are plotted for specimens from the Lakeview Limestone (solid trend line) and Siberia (dashed trend line). The slightly different trend lines are the result of smaller specimens from the Lakeview Limestone and the Siberian specimens being preserved in shale, which resulted in a lower $\mathrm{R}^{2}$ value (Lakeview $=0.95$ versus Siberia $=0.77$ ). Fewer specimens are from Australia and Canada, which have the distributions outlined. The fixigenal width is measured from the glabellar furrow adjacent to the S2 pit transversely to the palpebral lobe furrow. slightly anteriorly and moderately deep adjacent to axial furrows, shallower medially, extending to axial furrow; posterior margin moderately curved. Frontal area length $15 \pm$ $2 \%$ cranidial length. Anterior border concave, upturned, uniform length, moderately and evenly curved. Anterior border furrow evenly curved, very shallow, shallower than axial furrows. Very faint plectrum present extending from the junction of the ocular ridges and the glabella to the anterior lateral margin of cranidium. Fixigena width $64 \pm 8 \%$ glabellar width (K2), low convexity, level. Palpebral lobe narrow, width $15 \pm 3 \%$ lobe length; long, $60 \pm 3 \%$ glabellar length; anterior about opposite L4, $24 \pm 3 \%$ glabellar length behind anterior margin; moderate curvature; palpebral furrow moderate strength, broad. Ocular ridge absent. Posterior area of fixigena length $8 \pm 1 \%$ glabellar length; width $71 \pm 4 \%$ glabellar length; rounded termination with long fixigenal spine. Posterior border moderate convexity, slightly expanding distally; border furrow moderately deep, deepening and expanding distally, curved slightly posterolaterally.

Librigenae with spine 5.3-9.7 $\mathrm{mm}$ long $(\mathrm{N}=5)$; wide, width $64 \pm 7 \%$ length without spine; lateral margin moderately curved. Genal field slightly convex, width $46 \pm 3 \%$ librigenal width. Border width $22 \pm 2 \%$ librigenal width; flat, level; lateral border furrow moderately deep, shallowing towards posterior facial suture; posterior border furrow shallow, broad, very short. Anterior facial suture cuts nearly laterally across the anterior edge of librigenae. Genal spine slightly advanced, nearly flat in cross-section, long, length ranging $\sim 60-110 \%$ librigenal length.

Eight thoracic segments decreasing in width posteriorly. Axial furrows well defined. Thoracic pleura moderately wide, length (trans) $\sim 100 \%$ of axial width; anterior pleural band expanding distally, distal end forming long, flat, posterolaterally directed spine; posterior pleural band narrows distally, relatively low relief, persisting into pleural spine. Pleural spines directed posterolaterally, becoming posteriorly near pygidium.

Pygidium 1.4-3.7 mm long $(\mathrm{N}=12)$; subrectangular, length $53 \pm 3 \%$ width; anterior margin curved posterolaterally approximately half way to anterolateral corners; anterolateral corners rounded, adjacent to anterior portion of axis; five pairs of spines; projected posteriorly, decreasing is size posteriorly, spines terminate behind the posterior margin at nearly the same distance, enhancing the pygidial rectangular outline; moderately convex (sag.). Axis tapered, midwidth (AW2) $77 \pm 4 \%$ axial width (AW1), anterior width $40 \pm 3 \%$ pygidial width; length $77 \pm 4 \%$ pygidial length; three axial rings, moderately convex; terminal axial piece moderate size, rounded; axial ring furrows moderate strength. Pleural furrows and bands curved posterolaterally to posterior at back end, moderately to weakly developed from anterior to posterior. Border weakly defined by change in slope of pygidial spines. 

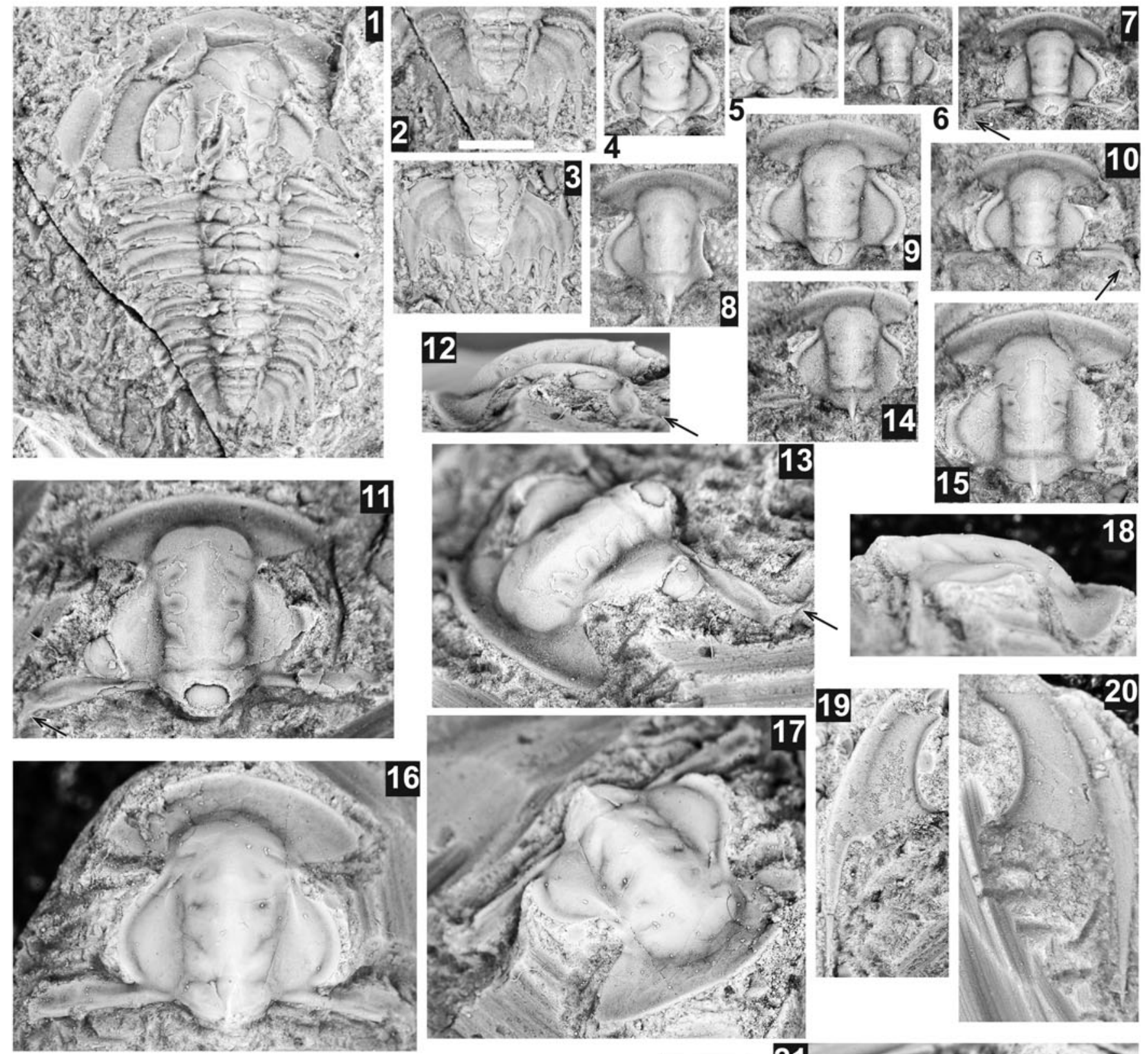

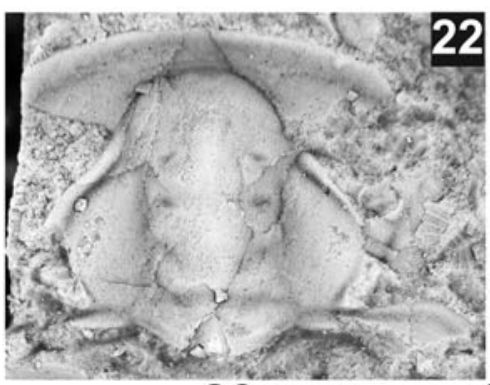

Fen

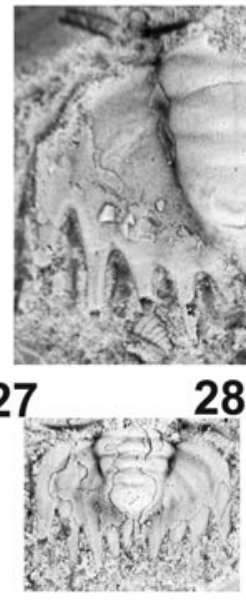

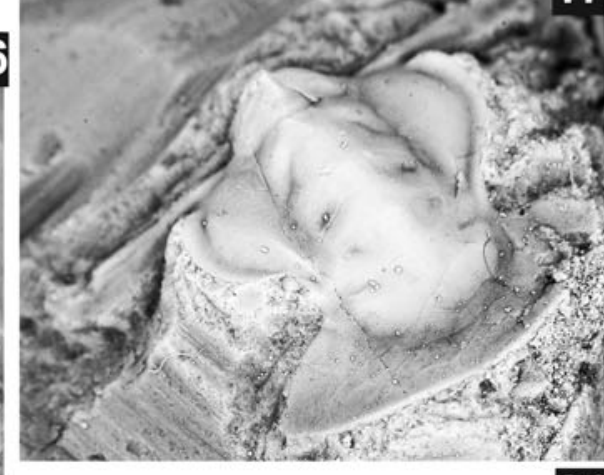

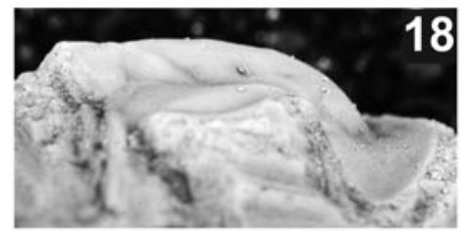

18

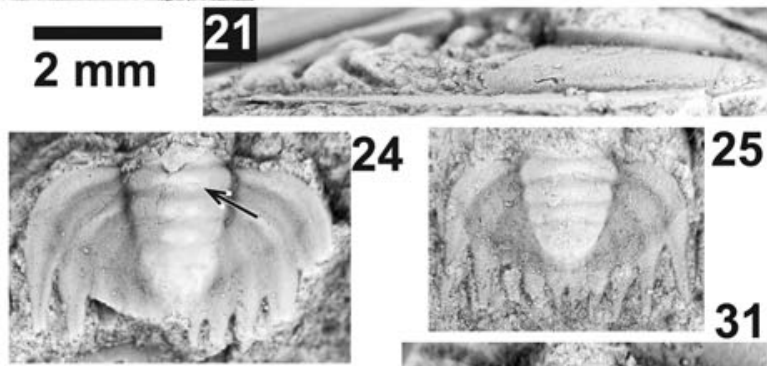

31

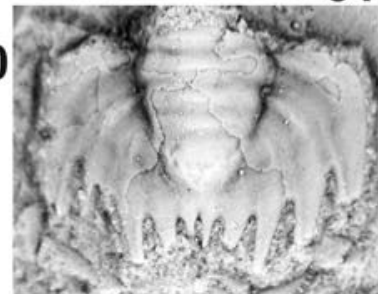

29 te 30
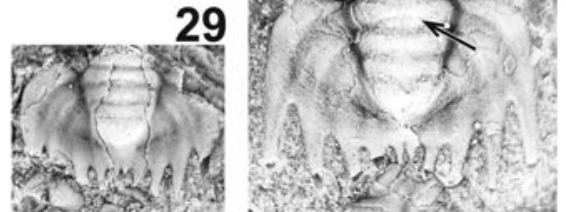
Figure 21. Zacanthoides sampsoni Resser, 1938a from the Ptychagnostus praecurrens Zone, Lakeview Limestone, Pend Oreille Lake, Idaho. (1-5) Resser's type specimens from USNM loc. 37n. (1, 2) Nearly complete holotype shield USNM 95043 and close-up of pygidium (white scale bar $=1 \mathrm{~mm}$ ), mostly exfoliated and crushed; (3) mostly testate, crushed, paratype pygidium USNM 95043c; (4) mostly testate, paratype cranidium USNM 95043a; (5) mostly testate, paratype cranidium USNM 95043b. (6-31) Topotype material, arrows indicate fixigenal spine on cranidium or articulating ring in pygidial axis. (6) Exfoliated cranidium USNM 724184 (USNM loc. 44279); (7) exfoliated cranidium USNM 724183 (USNM loc. 44279); (8) exfoliated cranidium USNM 724182 (USNM loc. 44279) illustrating occipital spine; (9) exfoliated cranidium USNM 724179 (USNM loc. 44279); (10) partially testate cranidium USNM 724180 (USNM loc. 44279); (11-13) partially testate cranidium USNM 724187 (USNM loc. 44279), dorsal, lateral, and oblique views; (14) exfoliated cranidium USNM 724185 (USNM loc. 44279) illustrating long occipital spine; (15) partially testate cranidium USNM 724186 (USNM loc. 44279); (16-18) partially testate cranidium USNM 724191 (USNM loc. 44282), dorsal, oblique, and lateral views; (19) exfoliated librigena USNM 724192 (USNM loc. 44282); (20, 21) exfoliated librigena USNM 724189 (USNM loc. 44279), dorsal and lateral views; (22) crushed, exfoliated cranidium USNM 724188 (USNM loc. 44279); (23) partially testate pygidium USNM 724177 (USNM loc. 44279 ); (24) exfoliated pygidium USNM 724194 (USNM loc. 44282); (25) exfoliated pygidium USNM 724197 (USNM loc. 44280); (26) testate pygidium USNM 724181 (USNM loc. 44279); (27) testate pygidium USNM 724190 (USNM loc. 44279); (28) mostly testate pygidium USNM 724196 (USNM loc. 44282); (29) mostly testate pygidium USNM 724195 (USNM loc. 44282); (30) mostly testate pygidium USNM 724178 (USNM loc. 44279); (31) mostly testate pygidium USNM 724193 (USNM loc. 44282).

Exoskeleton thin; generally smooth on all external and internal surfaces, except fine granular surface on some specimens (Fig. 21.11).

Remarks.-The cranidium of Z. sampsoni has a thin, long posterior area of the fixigenae and posterior border that is, in part, underneath the palpebral lobe and slopes downward (Fig. 21.12, 21.13). This makes it difficult to prepare specimens without damage to the palpebral lobe and/or the posterior area of the fixigena (Fig. 21.10). As a result, only a few specimens $(\mathrm{N}=10)$ were able to be used for comparison of cranidial width to other features. The pygidium has five pairs of marginal spines; however, the articulating ring of the second axial ring is visible in some specimens (Fig. 21.23, $21.24,21.27,21.30$, arrows). This suggests that the anterior-most section is incompletely fused. This feature occurs in pygidia of different sizes (Fig. 21.23 versus 21.27) and suggests that it is not related to ontogeny.

Zacanthoides sampsoni is most similar to $Z$. divergensis Rasetti, 1951 (s.l.) in their strongly divergent anterior facial suture and rectangular pygidium, which distinguishes these species from other representatives of Zacanthoides. The two species differ in the former having less-divergent anterior facial sutures ( $\sim 70^{\circ}$ versus $90^{\circ}$ to an exsagittal line) and lacking a plectrum, and five pygidial spines. Also mentioned is the presence of a granular surface (Sundberg, 1994, p. 48), however, some specimens of Z. sampsoni do have fine granular surface (Fig. 21.11).
In addition, Z. sampsoni has eight thoracic segments (versus nine), slightly more expanded glabella $(125 \pm 9 \%$ versus 105 $115 \%$ ), slightly wider fixigena ( $64 \pm 8 \%$ versus $45-60 \%$ glabellar width), and longer pygidial spines.

Order Pychopariida Swinnerton, 1915

Suborder Ptychopariina Richter, 1932

Remarks. - The middle Cambrian ptychopariids have been a taxonomic mess due to different authors giving priority to different morphological features or just assigning taxa to the suborder level. Assigning a specimen or a species to a genus has been difficult, particularly when specimens are commonly disarticulated, exfoliated, fragmented, ontogenetic changes have not been established, and/or compressed in shale. A landmark and semi-landmark study can help establish the amount of variation in a species due to compression, slight tectonic distortion, ontogeny, and natural variation. In this study, PCA and 16 landmarks (Table 1) are used to help establish the generic placement of Resser's species. The landmarks were selected to represent cranidial features considered to be taxonomically important.

\section{Genus Amecephalus Walcott, 1924}

Type species.-Ptychoparia piochensis Walcott, 1886, from the Chisholm Shale, Pioche Hills, Nevada.

Table 1. Description of landmark locations for the comparison of Amecephalus piochensis and Am. normale and the purpose behind a group of landmarks.

\begin{tabular}{|c|c|c|}
\hline Landmark & description & purpose \\
\hline 1 & anterior margin midline & \multirow{3}{*}{$\begin{array}{l}\text { Midline landmarks } 1-5 \text { generate information about the lengths of } \\
\text { anterior border, preglabellar area, glabella, and occipital ring. }\end{array}$} \\
\hline 2 & anterior border furrow midline & \\
\hline 3 & anterior glabella frontal lobe midline & \\
\hline 6 & anterior margin of intersection between glabellar axial furrow and ocular ridge & \multirow{4}{*}{$\begin{array}{l}\text { Landmarks } 3,6-12 \text { provide the outline of the glabella and the } \\
\text { location of the intersections of the ocular ridge (6) and lateral } \\
\text { glabellar furrows (7-11) with the axial furrow. }\end{array}$} \\
\hline 7 & intersection between glabellar axial furrows and $\mathrm{S} 4$ & \\
\hline 8 & intersection between glabellar axial furrows and S3 & \\
\hline 12 & posterior intersection between occipital ring and posterior border & \\
\hline 13 & intersection of the anterior border furrow and anterior facial suture & \multirow{3}{*}{$\begin{array}{l}\text { Landmarks } 13 \text { and } 14 \text { provide the width of the anterior margin, } \\
\text { convergent or divergent nature of the anterior facial suture. } \\
\text { Landmarks } 14 \text { and } 15 \text { provide the length and alignment of the } \\
\text { palpebral lobe }\end{array}$} \\
\hline 14 & anterior location of palpebral lobe & \\
\hline 15 & posterior location of palpebral lobe & \\
\hline 16 & posterior lateral corner of cranidium & $\begin{array}{l}\text { Landmark } 16 \text { provides the direction of the posterior facial suture and } \\
\text { length of the posterior area of the fixigena }\end{array}$ \\
\hline
\end{tabular}


Diagnosis.-Cranidia subrectangular to subpentagonal with moderate sagittal convexity. Glabella moderately elongated, ranging from $55-65 \%$ of cranidial length, strongly tapered from S0 to S2 then less tapered, lateral glabellar furrows bifurcated, deepest laterally, shallow to very shallow medially; axial furrows deepest posteriorly, preglabellar furrow shallow. S0 moderately shallow to medially obscure. Anterior border slightly tapered distally, no medial inbend, anterior border furrow moderately shallow laterally to shallow medially. Fixigena with intraocular region moderately to wide from 50 75\% glabellar width, slightly convex, level; anterior region moderately downsloping. Palpebral lobes relatively long, anterior set adjacent to S3 extending to or posterior of S1, moderately curved. Posterior area of fixigena strap-like with sharp termination, border widens distally; border furrow extends to suture. Anterior branches of facial sutures slightly to strongly divergent to anterior border; posterior branches strongly divergent to posterior border furrow, then nearly parallel. Librigena with wide genal area, spine moderate to long, flattened with shallow furrow extending into spine, broad-based. Thorax multisegmented, segments tapering posterior with moderate length pleural spines that become more posterolaterally directed posteriorly; fulcrum weakly developed. Pygidium suboval, micropygous; axis with one to three axial rings; poorly developed anterior pleural band; anterolateral corners rounded, opposite to the axis midlength; posterior margin with weak median notch arched in posterior view; doublure absent behind axis.

Remarks.-The diagnosis has been modified from Sundberg and McCollum (2000) to encompass the taxa from the Lakeview Limestone.

Discussion of type species.-The type material of Amecephalus piochensis (Walcott, 1886) was probably collected from mine dumps at the Half Moon Mine area near Pioche, Nevada. Walcott (1886) assigned a several specimens (USNM 15434) as syntypes (Fig. 22) and these may represent either three different species (Amecephalus piochensis, Alokistocare packi Resser, 1935, and Piochaspis sellata Levi-Setti, 1993) or one morphologically variable species. Resser (1935) assigned (USNM 90171, a-c, originally part of 15434; Fig. 22.1-22.5) to Alokistocare packi, but did not figure them. He also assigned a lectotype and paratypes (USNM 15434b) for Am. piochensis. Palmer (1954, pl. 16, fig. 5; Walcott, 1925 listed this specimen as 15434a and from USNM loc. 31) assigned the larger specimen as the holotype [lectotype] and reassigned Al. packi to Al. piochensis. Levi-Setti (1993) erected Piochaspis sellata, which is derived from the same locality as Walcott's specimens. Walcott (1925, pl. 15, fig. 10) figured an additional cranidium USNM 15434c, but it was not found in the type collection. In addition, the hypostome illustrated by Walcott (1886, pl. 28, fig. 1e) was not found in the type collection.

The lectotype assigned by Resser (USMN 15434b) is a nearly complete shield, part/counterpart that Walcott (1924, pl. 9, fig. 1) illustrated in naming the genus Amecephalus (Foster, 2011, fig. 10.1; Fig. 22.6, 22.7). The type collection has only one specimen (part/counterpart) labeled directly on the shale sample with ink as $15434 \mathrm{~b}$. This specimen, which was not illustrated by Palmer (1954), has a moderately long (sag.) and wide (trans.) anterior border, moderately wide (trans.) fixigena, long palpebral lobes, moderately long librigenal spine and an oval pygidium with faint pleural and interpleural furrows. Walcott (1886, pl. 26, fig. 2b; Fig. 22.9) also illustrated an isolated librigena (USNM 15434d) with a moderately long genal spine similar to the lectotype USNM 15434b.

The lectotype assigned by Palmer (USNM 15434a from USNM loc. 31 of Walcott, 1925; Fig. 22.10) has been illustrated by Walcott (1886, pl. 28, fig. 1; 1925, pl. 15, fig. 8) and Palmer (1954, pl. 16, fig. 5); however, this lectotype designation is invalid due to a prior designation by Resser (1935; ICZN Article 74.11; see International Commission on Zoological Nomenclature, 1999). This large cranidium has a broad anterior border, relatively short glabella, strongly curved S0 to S2 glabellar furrows, and extremely faint medial occipital furrow. These features separate this specimen from most of the other type specimens of Am. piochensis and differ from the lectotype in having a longer (sag.) and wider (trans.) anterior border, wider (trans.) fixigena and shorter palpebral lobes. USNM 15434c (Walcott, 1886, pl. 28, fig. 1a; Palmer, 1954, pl. 16, fig. 2; Fig. 22.8, 22.11), which is a nearly complete specimen lacking librigenae, shares those four features with the USNM 15434a, but is only half the size. The pygidium of this specimen is rectangular shape and has pleural and interpleural furrows, and laterally defined border.

One of Walcott's specimens (1886, pl. 28, fig. 1d; Foster, 2011, fig. 10.3; Fig. 22.1, USNM 90171a), which was assigned to Al. packi by Resser (1935) and Foster (2011), is identical to Piochaspis sellata (Levi-Setti, 1993, pl. 99) in its indentation of the anterior border into the preglabellar area, narrow intergenal area of the fixigena, relatively broad (trans.) width of the thoracic axial rings relative to the pleural lobes, thoracic pleural spines directed laterally to slightly posterolaterally, and librigenal spines short, pointed, directed $\sim 45^{\circ}$ to the posterior lateral and narrowed based.

The holotype specimen assigned to Al. packi by Resser (1935; Walcott, 1886, pl. 28, fig. 1c; Palmer, 1954, pl. 16, fig. 1, Foster, 2011, fig. 10.2; Fig. 22.4, 22.5;) is similar to P. sellata, but differs from this species in lacking a pronounced median inbend of the anterior border, relatively narrower width of the thoracic axial rings relative to the pleural lobes, librigenal spines longer, pointed, directed posteriorly, adjacent to the pleural lobes and broad based. Resser (1935) stated that there was only the holotype and a paratype, but four specimens are present in the type collection.

Palmer (1954) did not list two of Walcott's specimens (1886, pl. 26, fig. 2?, 2a?; Fig. 22.2, 22.3) as belonging to $A l$. piochensis. It is unclear if specimen USNM 90171b (Fig. 22.2) is the same as that figured by Walcott because the left palpebral lobe and adjacent fixigenae are missing, unlike the illustration in Walcott (1886). This specimen and USNM 90171c (Fig. 22.3) are on the same shale slab oriented nearly at $90^{\circ}$ to each other and illustrate tectonic distortion. These two specimens and an additional three specimens on the same slab do not illustrate an indentation of the anterior border and have wider anterior borders and intraocular region of the fixigena. It should be noted that the specimens are in dark green shale, as opposed to the typical brown shales containing the other type material that is not tectonically distorted. Walcott 

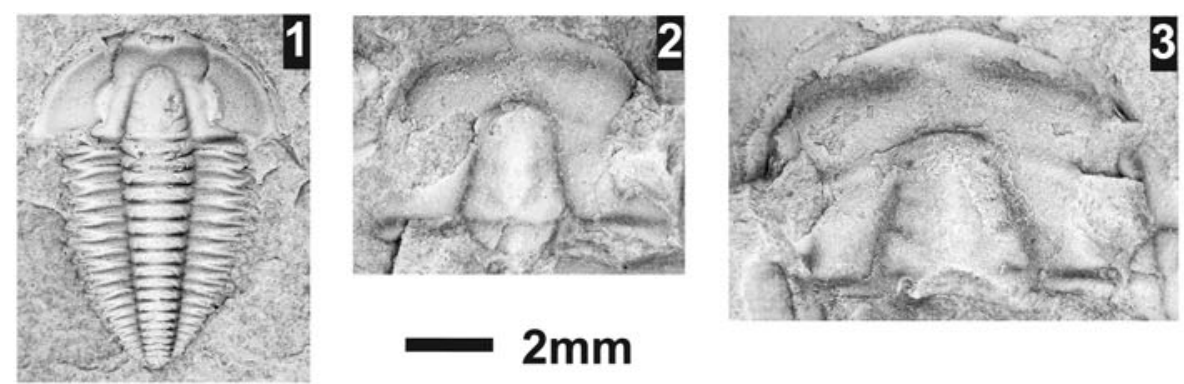

\section{$2 \mathrm{~mm}$}
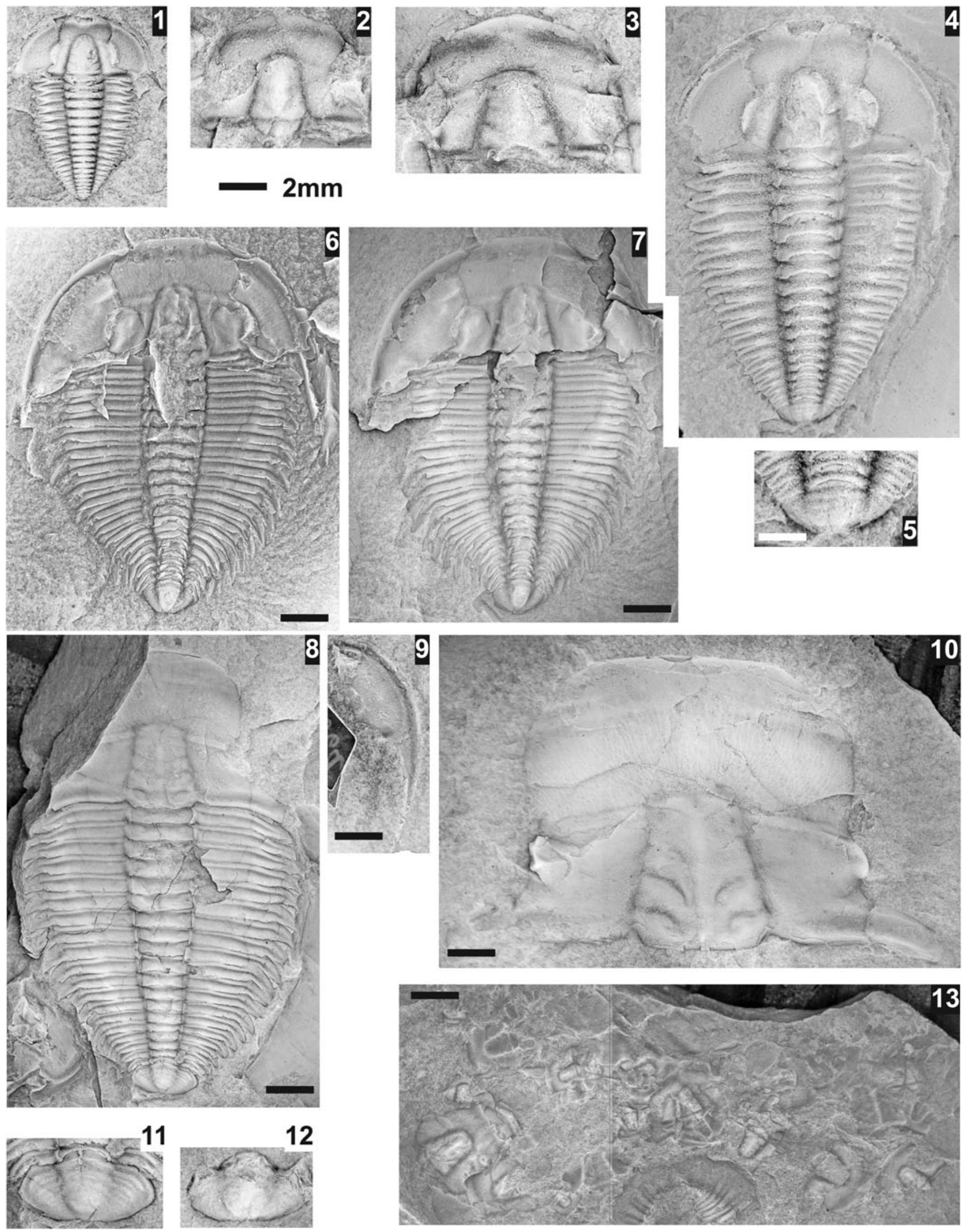

12
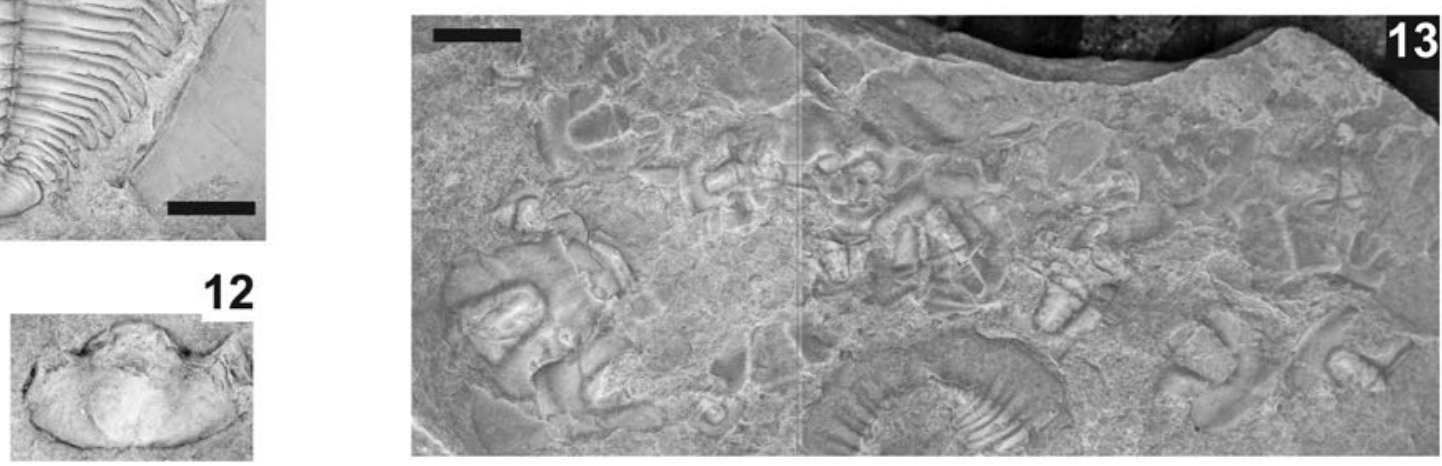
Figure 22. Type specimens of Amecephalus piochensis (Walcott, 1886) from the Glossopleura walcotti Zone, Chisholm Formation, Half Moon Mine, Pioche, Nevada. All specimens from USNM loc. 31. White scale bar $=1 \mathrm{~mm}$; black scale bar $=4 \mathrm{~mm} ;(\mathbf{1 - 4 , 1 1 , 1 2})$ use the $2 \mathrm{~mm}$ scale. (1-5) Walcott specimens that Resser assigned to Alokistocare packi Resser, 1935. (1) Nearly complete shield, paratype (USMN 90171a), but is identical to Piochaspis sellata Levi-Setti, 1993; (2, 3) Distorted and fragmented cranidia of paratypes (USMN 90171b, c) occurring on the same slab of shale; $(\mathbf{4}, \mathbf{5})$ holotype (USMN 90171) and close-up of pygidium. (6-13) Type specimens presently retained in Amecephalus piochensis. $(\mathbf{6}, 7)$ Part/counterpart of lectotype nearly complete shield (USMN 15434b), (6) is the counterpart that has been digitally inverted and flipped to match the part; $(\mathbf{8}, \mathbf{1 1})$ nearly complete shield of paralectotype (USMN 15434c), with close-up of pygidium; $(\mathbf{9})$ Isolated librigena paralectotype (USMN 15434d), counterpart that has been digitally inverted and flipped; (10) paralectotype (USMN 15434) assigned as "holotype" for the species by Palmer (1954); (12) isolated pygidium paralectotype (USMN 15434d); (13) slab of several moderately preserved cranidia in type collection, paralectotype (USMN 15434e).

(1886, p. 34) did note that Ptychoparia piochensis occurs in two different levels (7 and 21) more than $1055 \mathrm{ft}(320 \mathrm{~m})$ apart. The lower report is only $96 \mathrm{ft}(29 \mathrm{~m})$ above Olenellus gilberti Meek in White, 1874, and this green slab could be from this locality.

Additional specimens in the type collection include a small pygidium (Fig. 22.12; not illustrated by Walcott, 1886) with same general features as USNM 15434e (Fig. 22.11), but more poorly preserved and several cranidia of the same general type (Fig. 22.13; not illustrated by Walcott, 1886) as in USNM 15434b (Fig. 22.6, 22.7).

In addition, Pack (1906) reported taxa from the shales near Half Moon Mine (Chisholm Shale), which included Ptychoparia piochensis and Ptychoparia kempi Pack, 1906. Pack stated that all the material is in the collections at Columbia University Museum under the catalog numbers 20018-20021 (P. piochensis) and 20023 (P. kempi). All illustrations in Pack are drawings, which lack the detail to determine what species they may be. Specimens in plate 2, figures $4,4 \mathrm{a}$, and $4 \mathrm{~b}$ may belong to $\mathrm{Al}$. packi. The hypostome illustrated in figure $4 \mathrm{c}$ belongs to a corynexochid. The single specimen of $P$. kempi in plate 3, fig. 1 , is clearly the same as the lectotype of $P$. piochensis.

Discussion of Lakeview Limestone species.-Resser (1938a) identified six species of "Alokistocare" from the Lakeview Limestone. Alokistocare normale (pl. 1, fig. 44) was stated (p. 7) to be "much like A. subcoronatum except for its larger size. Also the furrows, eyelines, and distribution of relief in the brim are different." Alokistocare noduliferum (pl. 1, figs. 52,54 ) was stated (p. 7) to have "a wide brim, the test is finely and coarsely granulated, the brim is striated beneath the test, and two nodes are situated in the dorsal furrow a short distance forward of the occipital furrow." Alokistocare natale (pl. 1, fig. 53) is differentiated from Al. noduliferum in (p. 7) "the surface ... is finely granulated, has, in addition scattered larger granules." Alokistocare nactum (pl. 1, fig. 41, 42) (p. 7) "is characterized by a medium brim, on which a rather wide flat brim is differentiated by its upturned position." Alokistocare nothum (pl. 1, fig. 51,55 ) is compared to Al. nactum, but has (p. 7) "A medium swelling causes the rim to be less even in width throughout." Alokistocare notatus (Resser, 1938a, pl. 1, fig. 43) is stated (p. 8) to have higher convexity and "test is finely granulated, and only a narrow rim is differentiated by the upturned edge."

One of the obvious differences between Resser's species is the size of the specimens, with Al. noduliferum and Al. notatus based on larger specimens (glabellar length $>10.0 \mathrm{~mm}$ ); Al. normale and Al. nactum based on medium-sized specimens (glabellar length 6.0-8.0 mm); and Al. natale and Al. nothum based on a small specimens (glabellar length $2.0-4.0 \mathrm{~mm}$ ). At present, three species can be recognized and assigned to Amecephalus: (1) Am. noduliferus (including Al. natale) based on the bacculae next to the base of the glabella and fine granular ornamentation; (2) Am. notatus (including Al. nothum) based on the welldeveloped false anterior furrow, relatively narrow anterior border and coarse granular ornamentation; and (3) Am. normale (including $\mathrm{Al}$. nactum) based on the very poorly developed false anterior furrow, relatively long (sag.) anterior border, no bacculae, and fine granular ornamentation. With the exception of the bacculae, the smaller specimens $(<4.0 \mathrm{~mm})$ of the last two groups are difficult to distinguish, in part due to the exfoliation of the exoskeleton and the difficulty of removing the exoskeleton from the internal mold. The adherence of the exoskeleton to the exterior mold is the result of its external granular surface and a thin layer of spar calcite that forms on the internal portion of the sclerite that provides a parting surface. Some species of Amecephalus have a frontal area that contains an anterior false border furrow and a posterior true anterior furrow. This term was defined and justified by Fortey and Ruston (1976, p. 337).

PCA plots (Fig. 23) illustrate a considerable overlap in cranidial measures in smaller specimens of Am. notatus and Am. normale. Amecephalus noduliferus occupies a separate morphospace, if size is ignored (PC1). The two specimens of "Al." nothum overlaps with Am. normale and the two specimens of "Al." nactum occur in separate morphospace between Am. notatus and Am. noduliferus.

\section{Amecephalus normale (Resser, 1938a)}

Figures 24, 25

1938a Alokistocare normale Resser, p. 7, pl. 1, fig. 44.

1938a Alokistocare nactum Resser, p. 7, pl. 1, figs. 41, 42.

1939a Alokistocare idahoense Resser, p. 16, pl. 4, figs. 8, 9.

1939a Alokistocare spencense Resser, p. 16, pl. 4, figs. 10, 11.

1981 Alokistocare idahoense; Gunther and Gunther, p. 17, pl. 3, figs. A-C.

2015 Amecephalus idahoense; Robison et al., fig. 61.

\section{Holotype.-Cranidium USNM 95028 from USNM loc. 37n.}

Diagnosis. - Cranidium subtrapezoidal, moderate length frontal area (36 $\pm 3 \%$ cranidial length), nearly parallel anterior facial sutures, anterior border moderately wide (width $61 \pm 7 \%$ cranidial width) and narrow (length $16 \pm 2 \%$ cranidial length), false anterior furrow absent; genal caeca well developed on preglabellar field; palpebral lobes dorsally arched; fixigena slightly convex, gently sloping upwards; bacculae absent. Librigenae with genal caeca; genal spine relatively short (length $\sim 60 \%$ librigenal length), broad based with shallow 


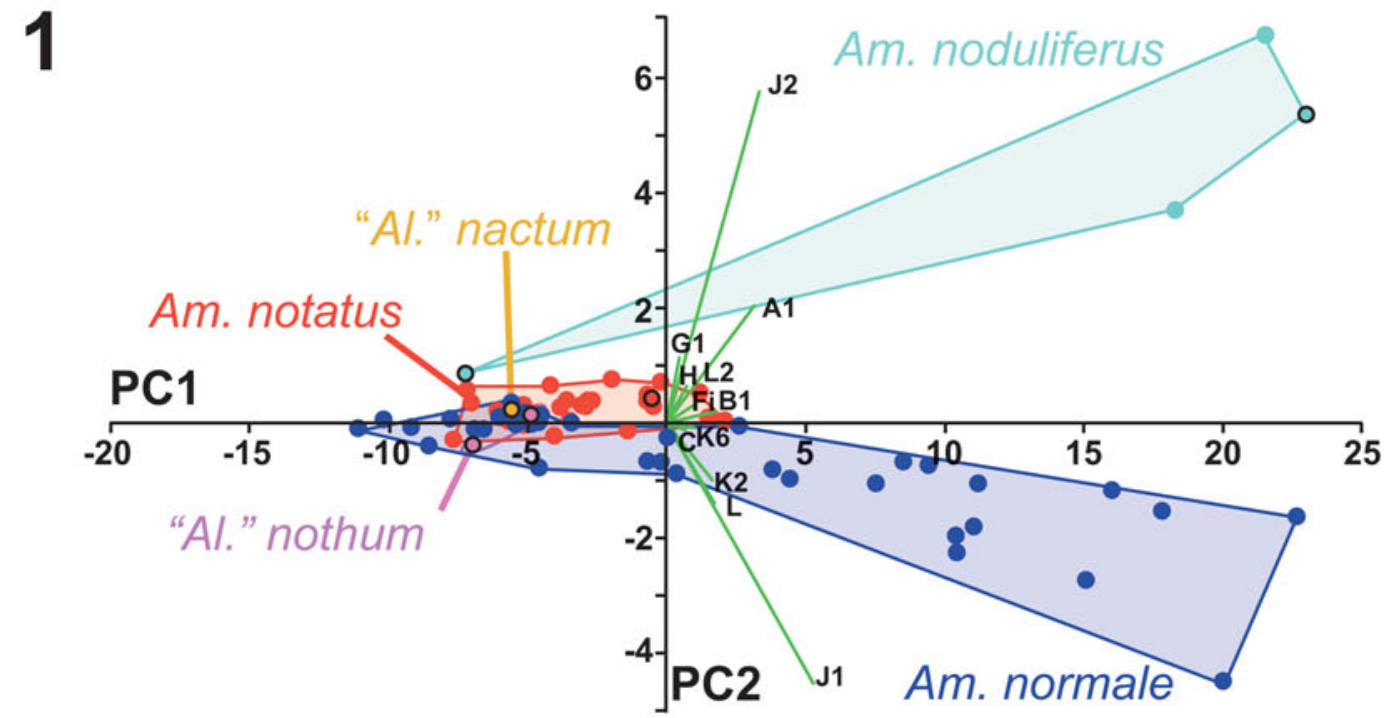

2
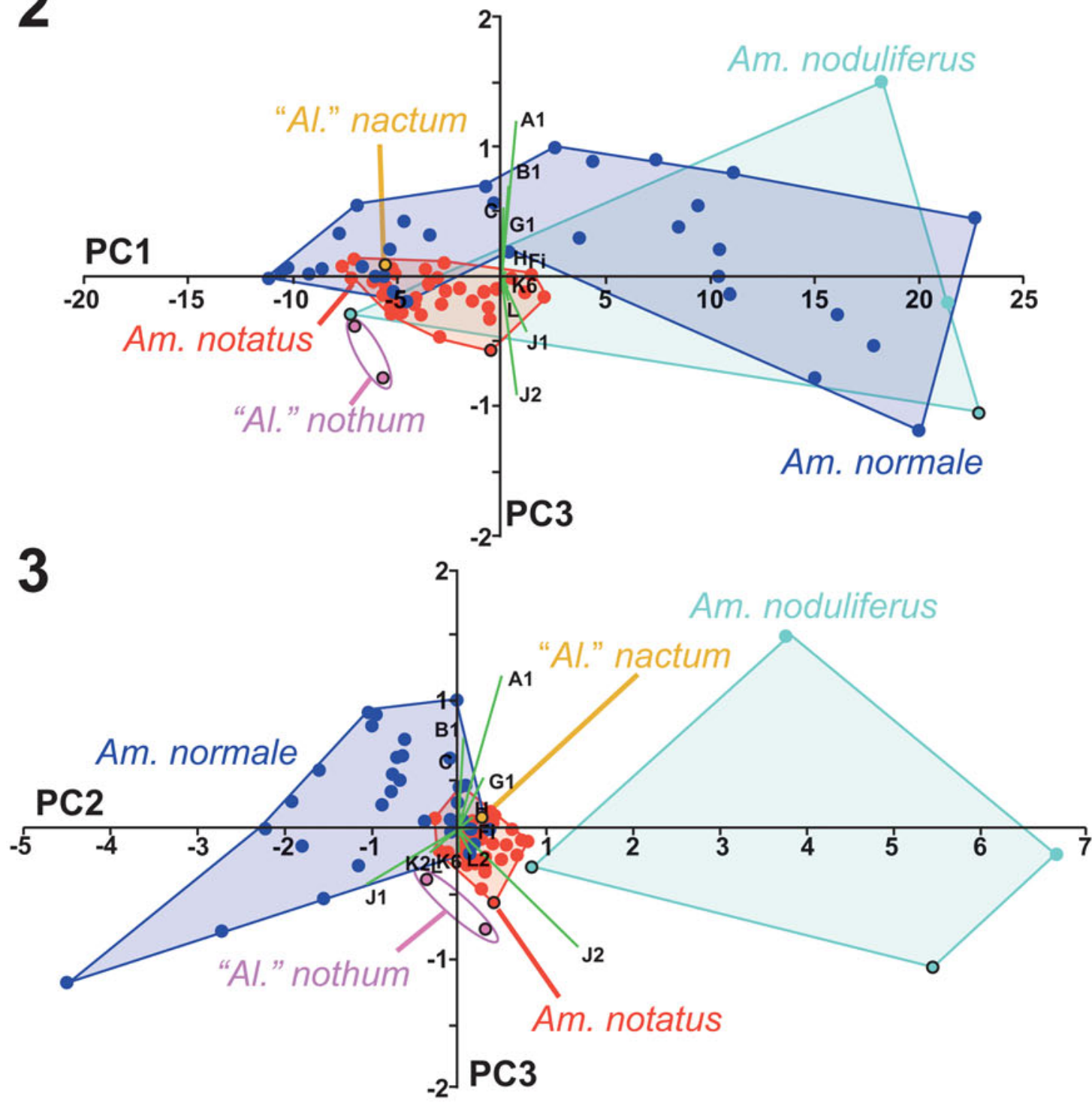

Figure 23. Principal component (PC) plots of Resser's type material of "Alokistocare" (points with black outlines) and additional material (colored outlines) from the Lakeview Limestone. (1) PC1 versus PC2 plot; (2) PC1 versus PC3; (3) PC2 versus PC3. Generic abbreviations: Am. represents taxa assigned to Amecephalus herein; "Al." represents taxa that were assigned to Alokistocare by Resser (1938a), but considered as synonyms of the species assigned to Amecephalus herein. The type specimens of Am. normale (Resser, 1938a) and "Al." natale Resser, 1938a, are not included due to incomplete preservation. 
lateral border furrow extending into spine. Pygidia nearly effaced, faint border furrow and anterior pleural furrow, anterior lateral corners located at the level of the posterior axial lobe, anterior margin strongly curved posterolaterally approximately $1 / 3$ distance from axial lobe. Cranidium and librigena covered in fine granular ornamentation.

Occurrence.-Lakeview Limestone (Ptychagnostus praecurrens Zone), Pend Oreille Lake, Idaho. Spence Shale (Glossopleura walcotti Zone), Wasatch Mountains and Wellsville Mountains, Utah (Resser, 1939a; Campbell, 1974; Robison et al., 2015).

Description.—Cranidium $6.9 \pm 3.4 \mathrm{~mm}$ long $(\mathrm{N}=35)$; subtrapezoidal; anterior border width $61 \pm 7 \%$ cranidial width, cranidial length $65 \pm 7 \%$ cranidial width; moderate convexity (sag. and trans.); anterior margin evenly curved to slightly uneven, slightly arched dorsally; posterior margin, excluding occipital ring, distally curved posterolaterally. Anterior branches of facial sutures nearly parallel to anterior border; strongly convergent across anterior border; posterior branches strongly divergent. Glabella moderately elongated, length 63 $\pm 3 \%$ cranidial length; width $33 \pm 2 \%$ cranidial width, moderately tapered, width at anterior end $64 \pm 6 \%$ glabellar width; moderate convexity (sag. and trans.); frontal lobe rounded; length $63 \pm 3 \%$ cranidial length; width $33 \pm 2 \%$ cranidial width. Axial furrow moderately deep, slightly deeper posteriorly, slightly constricted at L2; preglabellar furrow moderately shallow. Lateral glabellar furrows moderate to shallow, S1 bifurcated posterior branch directed to center of occipital furrow; S2-S4 not bifurcated directed laterally to slightly anterior, S4 very faint or absent. Occipital ring slightly elevated above glabella, moderate convexity; small occipital node; length $20 \pm 3 \%$ glabellar length; posterior margin convex posteriorly, slightly curved medially. S0 gently curved anteriorly, moderately deep, and lateral portions arched anteriorly and deeper. Bacculae absent. Frontal area nearly equally divided; length $36 \pm 3 \%$ cranidial length. Preglabellar field slightly convex, moderately downsloping, length $55 \pm 5 \%$ frontal area length. Anterior border nearly flat and level, stronger curve medially, straighter laterally, slightly tapering laterally, length $16 \pm 2 \%$ cranidial length. Anterior border furrow shallow, shallower medially, shallower than axial furrows; false anterior furrow absent. Fixigena slightly convex, gently sloping upwards, anterior area slightly downsloping; width $56 \pm 5 \%$ glabellar width. Palpebral lobes moderately curved, sloping up, narrow, moderately long, length $46 \pm 4 \%$ glabellar length; anterior margin located opposite L4. Ocular ridge moderate strength, very faint double band in larger specimens, slightly curved, directed moderately posterolaterally from glabella at $75 \pm 3^{\circ}$ to axis. Posterior area of fixigena strap like, sharp, nearly $90^{\circ}$ termination; length (exsag.) $28 \pm 3 \%$ glabellar length; width $82 \pm 11 \%$ glabella length.

Librigenae $1.9-10.3 \mathrm{~mm}$ long excluding spine $(\mathrm{N}=5)$; wide, width $51 \pm 5 \%$ length without spine; lateral margin moderately curved. Genal field moderately convex. Border slightly convex, wider posteriorly, width $\sim 22 \pm 5 \%$ librigenal width; border furrows moderate, shallower posterior and extending down into spine. Librigenal spine moderately long, 45-60\% librigenal length $(\mathrm{N}=2)$, slightly curved, flattened.

Rostral plate and hypostome unknown.

Thorax with at least 21 segments, tapering towards very small pygidium (pygidial width $\sim 25 \%$ cranidial width). Pleural segments wider than axial ring, directed laterally, directed moderately posterolaterally at moderately developed fulcrum. Anterior and posterior pleural bands strongly convex and uniform in length. Interpleural furrow deep and narrow to fulcrum, then shallowing. Pleural spine moderately short length, termination sharp.

Pygidium $0.9-1.57 \mathrm{~mm}$ long $(\mathrm{N}=4)$; nearly oval to aleate, length $40 \pm 4 \%$ width; margin smooth, anterior margin curved posterolaterally approximately half way to anterolateral corners; anterolateral corners moderately rounded, adjacent to anterior portion of axis; posteromedial notch present(?); moderately convex (sag.). Axis anterior width $37 \pm 3 \%$ pygidial width; length $89 \pm 5 \%$ pygidial length; postaxial ridge absent; slightly tapered, medial width $89 \pm 5 \%$ anterior width, three axial rings, moderately convex; terminal axial piece moderate size(?), rounded; axial ring furrows nearly effaced in smaller specimens. Pleural regions moderately curved laterally; pleural furrows and bands poorly developed except anterior pair. Border weakly defined; border furrow very shallow anteriorly.

Exoskeleton with a fine granular surface; preglabellar area and genal area of librigenae covered with genal caeca.

Remarks.-Amecephalus normale ranges in cranidial length from 2.1-15.1 mm (Fig. 26.1). With this range in size, there are some significant changes in morphology due to ontogeny, which include a decrease in cranidial length to width from $75 \%$ to $55 \%\left(\mathrm{R}^{2}=0.60\right.$; Fig. 26.2) and anterior cranidial width to posterior cranidial width from $70 \%$ to $55 \%\left(\mathrm{R}^{2}=\right.$ 0.44; Fig. 26.3). Other decreases, but much less constrained, are glabellar length to cranidial length $\left(64 \%\right.$ to $62 \%, \mathrm{R}^{2}=$ $0.05)$; glabellar anterior with to basal glabellar width $(67 \%$ to $57 \%, \mathrm{R}^{2}=0.19$ ); palpebral lobe length to glabellar length ( $47 \%$ to $42 \%, \mathrm{R}^{2}=0.25$ ); and anterior border width to frontal area width $\left(48 \%\right.$ to $\left.40 \%, \mathrm{R}^{2}=0.16\right)$. The ratio of glabellar width to length increases with cranidial size (70\% to $90 \%, \mathrm{R} 2=0.60$, Fig. 26.4)

Alokistocare nactum Resser, 1938a is included within the species, given their similarity to smaller specimens of Am. normale (Figs. 23, 24.3, 24.4, 26).

PCA of the specimens assigned to Am. normale and Am. notatus illustrate that the two taxa occupy distinct morphospaces, but overlap occurs in relatively smaller specimens (Fig. 23). Samples from the Lakeview Limestone were assigned to one or the other species based on (1) fine or coarse granules, and/or (2) presence or absence of the false anterior furrow. However, the common exfoliation of specimens makes it difficult to determine if a specimen has either fine or coarse granules, and the false anterior furrow absent is poorly developed in smaller specimens (the relatively thick exoskeleton hampers the effort to identify the false anterior furrow as absent).

In many aspects, Am. normale is similar to specimens of Am. piochensis (Walcott, 1886), re-illustrated by Palmer (1954, pl. 16, figs. 1, 2, 5; Fig. 22.4, 22.8). The two smaller paratypes (cranidial lengths of $14.1 \mathrm{~mm}$ and $6.5 \mathrm{~mm}$ ) illustrated by 


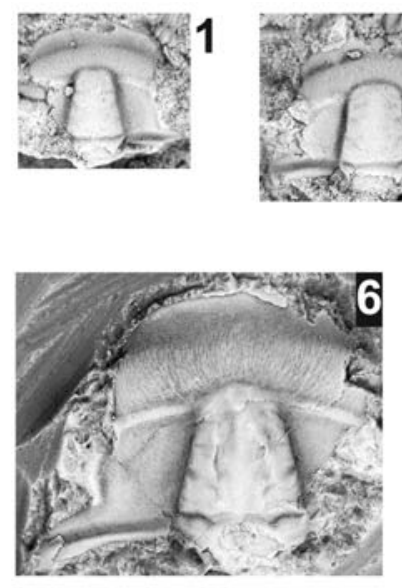

\section{2}
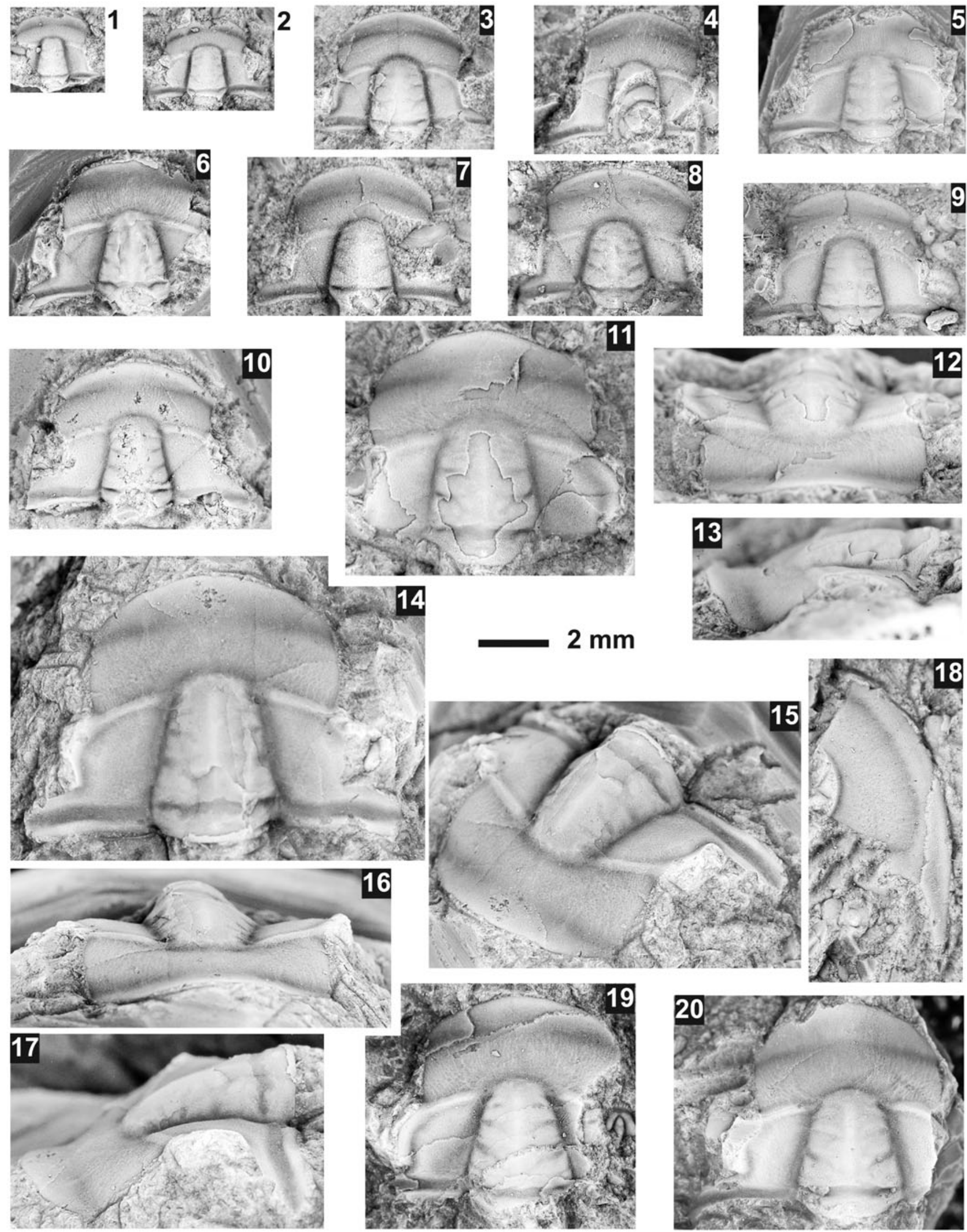

\section{$2 \mathrm{~mm}$}
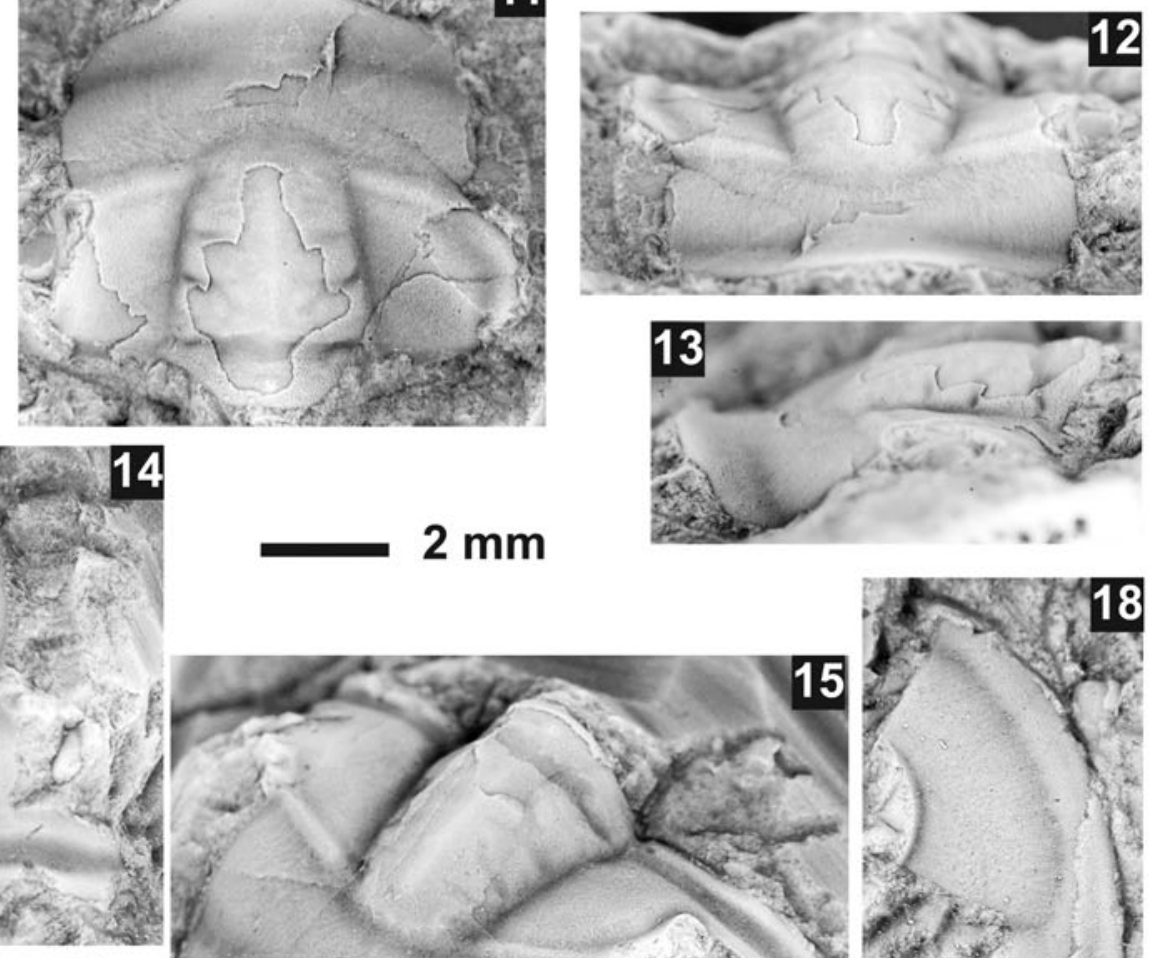

\section{6}
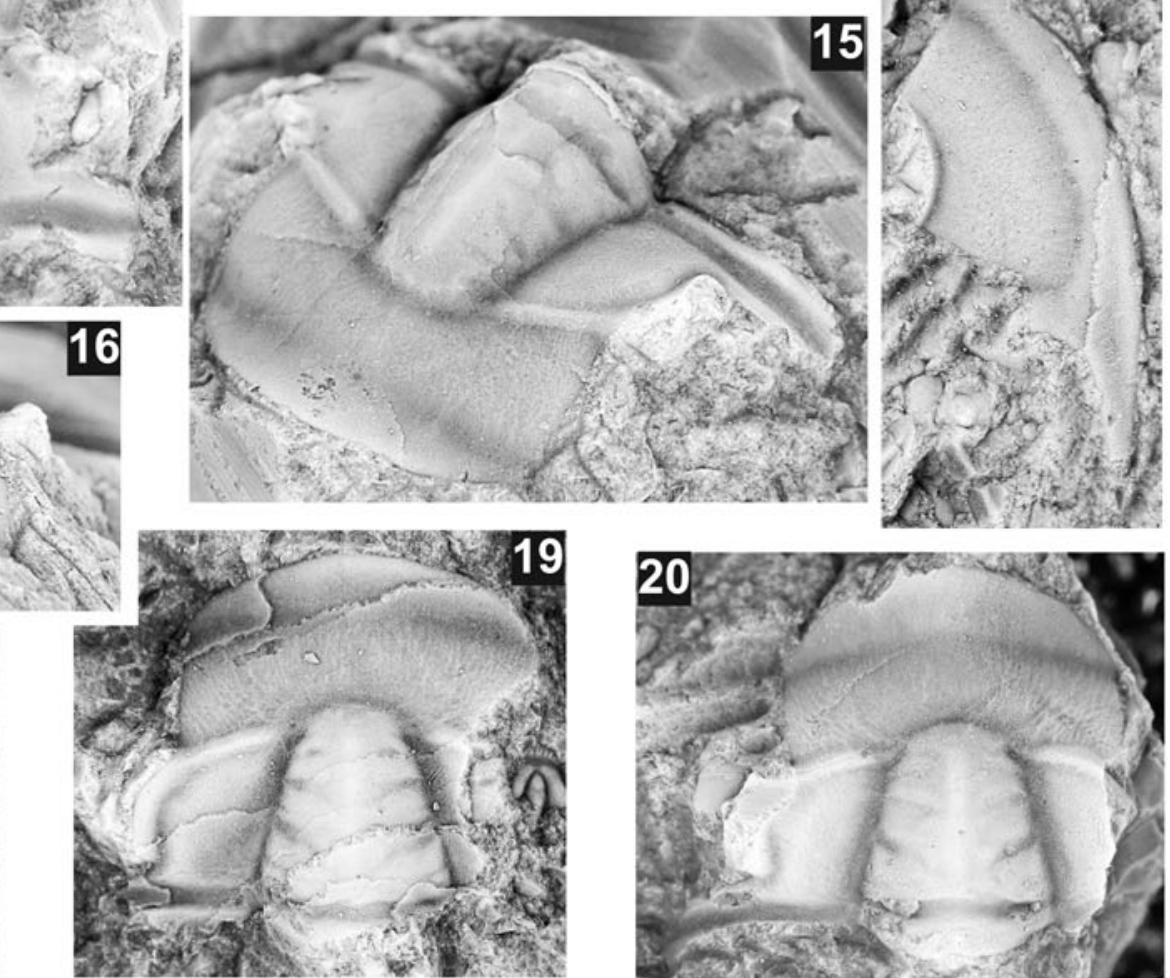


\begin{abstract}
Figure 24. Amecephalus normale (Resser, 1938a), from the Ptychagnostus praecurrens Zone, Lakeview Limestone, Pend Oreille Lake, Idaho. (1) Exfoliated cranidium USNM 723954 (USNM loc. 44280); (2) exfoliated cranidium USNM 723953 (USNM loc. 44280); (3) Resser's holotype of Alokistocare nactum, exfoliated cranidium USNM 95032 (USNM loc. 37n); (4) Resser's paratype of Alokistocare nactum, exfoliated cranidium USNM 95032a (USNM loc. 37n); (5) partially testate cranidium USNM 723958 (USNM loc. 44282); (6) exfoliated, partial cranidium USNM 723956 (USNM loc. 44282); (7) exfoliated cranidium USNM 723942 (USNM loc. 44280); (8) latex cast of testate cranidium USNM 723963 (USNM loc. 44282); (9) latex cast of testate cranidium USNM 723952 (USNM loc. 44280); (10) exfoliated cranidium USNM 723951 (USNM loc. 44280); (11-13) Resser's holotype of Alokistocare normale, mostly testate cranidium USNM 95028 (USNM loc. loc. 37n), dorsal, posterior, and lateral views; (14-17) exfoliated cranidium USNM 723948 (USNM loc. 44280), dorsal, oblique anterior, and lateral views; (18) mostly exfoliated librigena USNM 723966 (USNM loc. 44280); (19) mostly exfoliated cranidium USNM 723957 (USNM loc. 44282 ); (20) exfoliated cranidium USNM 723955 (USNM loc. 44282).
\end{abstract}

Palmer and additional material collected by the author (Fig. 27) are similar in: glabella shape and convexity; frontal area construction with a medially upturned anterior border; intraocular fixigenae sloping upwards, slightly convex and of similar width; palpebral lobes tilted upwards; posterior portion of the fixigena down sloping and bluntly terminated; librigenae with moderately long, broad base spine and a border furrow extending into spine; thoracic segments with relatively short pleural spines; and pygidia with a relatively short transverse width. Differences are relatively minor and Am. piochensis has a slightly coarser granulation (Fig. 25.6), slightly wider anterior border (trans.), and slightly narrower posterior margin width (trans.). The difference in transverse widths is illustrated by comparing 16 landmarks between the two species (Fig. 28). The differences between Am. piochensis and Am. normale are, in the former: a very slightly more constricted glabella margin (Fig. 28.2, landmarks 6-12; sagittal landmarks 1-5 are about the same); and the larger differences in the abaxial landmarks (13-15) are occurring outward. This essentially creates a stronger curvature of the anterior border, wider anterior border, shorter anterior facial suture between the anterior border furrow and the anterior end of the palpebral lobes, and overall widening of the anterior half of the cranidium. Principal component analysis on the landmarks indicates that the distribution of the two taxa is different (Fig. 28.3, 28.4).

These significant differences may be the result of compaction given that Am. normale is preserved in limestone and Am. piochensis and Am. idahoense are preserved flattened in shale. Figure 28.2 illustrates that generally movement of landmarks are inwards in the posterior portion of the cranidium and outwards in the anterior portion. Distribution of cracks on specimens of Am. piochensis (Fig. 29) is concentrated in the center of the frontal area, center of the occipital ring, at the anterior end of the palpebral lobes, at the junction of the posterior area of the fixigena and occipital ring, and posterior from the palpebral lobe to the posterior margin. The cracks in the frontal area could easily expand the transverse width, but it is unknown if other cracks would shorten the transverse widths from the anterior margin of the palpebral lobes to the posterior margin of the cranidium. Although these similarities and compressional changes would suggest a synonymy of the two species, a complication arises when the lectotype of $\mathrm{Am}$. piochensis (Palmer, 1954, pl. 16, fig. 5) is considered as discussed above.

Resser (1939a) proposed five new species of Alokistocare from the Spence Shale of Idaho: Al. septum, Al. idahoense, Al. spencense, Al. laticaudum, and Al. puncatum. Of these, Al. idahoense and Al. spencense are considered as junior synonyms of Am. normale from the Lakeview Limestone.
Amecephalus idahoense illustrated by Robison et al. (2015, fig. 61) have identical glabellar, librigenae, and pygidial features to Am. normale.

Amecephalus althea (Walcott, 1916a) from the Bright Angel Formation (McKee and Resser, 1945; Foster, 2011) and Am. normale are similar in both having a relatively narrow fixigena and relatively wide and long palpebral lobes, but differ in the former having a triangular frontal area swelling and very long fixigenal spines.

\section{Amecephalus noduliferus (Resser, 1938a)} Figures 30, 31

1938a Alokistocare noduliferum Resser, p. 7, pl. 1, figs. 52, 54. 1938a Alokistocare natale Resser, p. 7, pl. 1, fig. 53.

2015 Amecephalus laticaudum (Resser, 1939a); Robison et al., fig. 63.

Holotype.-Cranidium USNM 95029 from USNM loc. 37n.

Paratype.-Cranidium USNM 95029a from USNM loc. 37n.

Diagnosis. - Cranidium subsquare, with long frontal area $(45 \pm$ $1 \%$ cranidial length), divergent anterior facial sutures, anterior border transversely wide (width $93 \pm 8 \%$ cranidial width) and sagittally narrow (length $22 \pm 2 \%$ cranidial length), false anterior furrow present; genal cecea well developed on preglabellar field; palpebral lobes dorsally arched; fixigena flat, gently sloping upwards; bacculae present. Librigenae with genal caeca; genal spine relatively long (length $\sim 100 \%$ librigenal length), broad based with deep lateral border furrow extending into spine. Pygidia nearly effaced, faint border furrow and anterior pleural furrows, anterior lateral corners located at the level of the posterior axial lobe, anterior margin strongly curved posterolaterally approximately $1 / 3$ distance from axial lobe. Cranidium and librigena covered in fine granular ornamentation.

Occurrence.-Lakeview Limestone (Ptychagnostus praecurrens Zone), Pend Oreille Lake, Idaho. Spence Shale (Glossopleura walcotti Zone), Wellsville Mountains, Utah (Robison et al., 2015).

Description.—Cranidium $11.8 \pm 6.8 \mathrm{~mm}$ long $(\mathrm{N}=6)$; subsquare, anterior border width $93 \pm 8 \%$ cranidial width, cranidial length $78 \pm 3 \%$ cranidial width; moderate convexity (sag. and trans.); anterior margin evenly curved, very slightly arched dorsally; posterior margin, excluding occipital ring, distally curved posterolaterally. Anterior branches of facial 

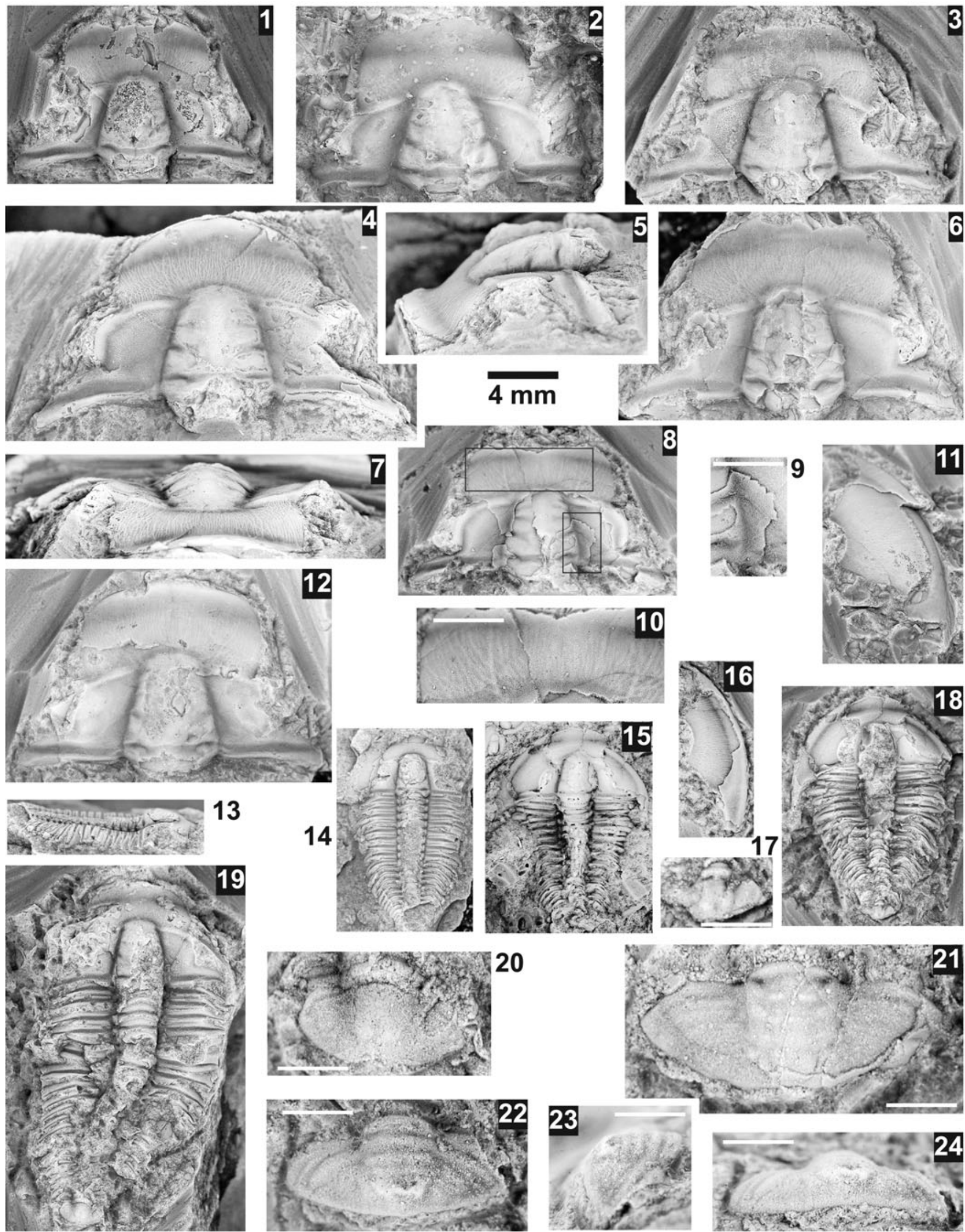

14
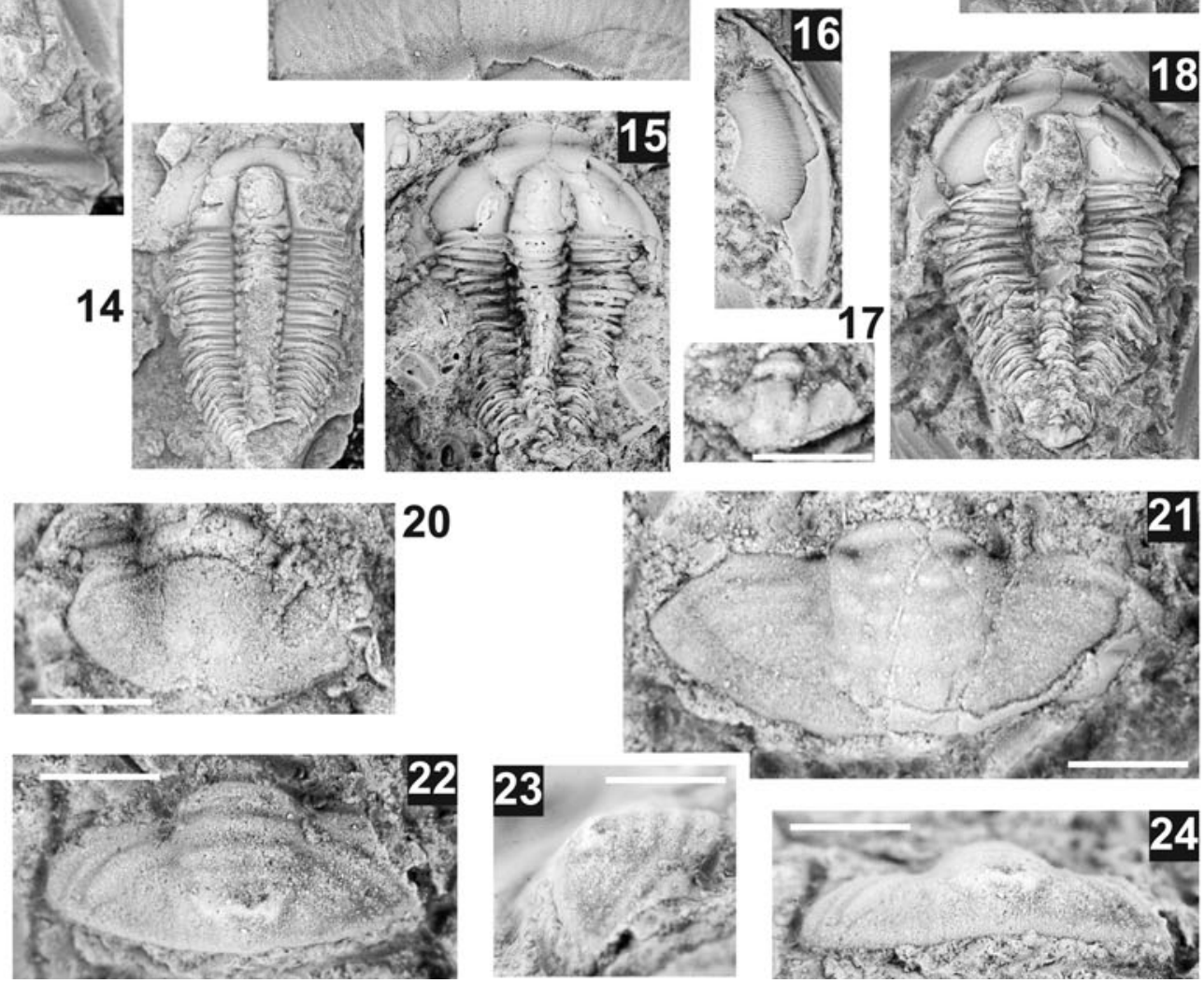


\begin{abstract}
Figure 25. Amecephalus normale (Resser, 1938a), from the Ptychagnostus praecurrens Zone, Lakeview Limestone, Pend Oreille Lake, Idaho. White scale bars are $1 \mathrm{~mm}$. (1) Exfoliated cranidium USNM 723947 (USNM loc. 44280); (2) latex cast of testate cranidium USNM 723945 (USNM loc. 44280 ); (3) exfoliated cranidium USNM 723944 (USNM loc. 44280); (4, 5, 7) partially testate cranidium USNM 723943 (USNM loc. 44280), dorsal, lateral, and anterior views; (6) exfoliated cranidium USNM 723946 (USNM loc. 44280); (8-10) partially testate cranidium USNM 723959 (USNM loc. 44282), dorsal view, close-ups of base of glabella and frontal area, as show in boxes on dorsal view; (11) broken, partially testate librigena USNM 723962 (USNM loc. 44282); (12) mostly exfoliated cranidium USNM 724214 (USNM loc. 44282); (13, 14) mostly exfoliated shield USNM 723965 (USNM loc. 44279) with at least 17 thoracic segments, lateral and dorsal view; (15, 17, 18) mostly testate shield USNM 723949 (USNM loc. 44280) with at least 18 thoracic segments, latex cast, close-up of pygidium, and dorsal view; (16) partially testate librigena USNM 723950 (USNM loc. 44280; (19, 20) mostly exfoliated shield USNM 723965 (USNM loc. 44279) with at least 19 thoracic segments, dorsal view and close-up of pygidium; (21) exfoliated pygidium USNM 723961 (USNM loc. 44282); (22-24) exfoliated pygidium USNM 723960 (USNM loc. 44282 ), dorsal, lateral, and posterior views.
\end{abstract}

sutures divergent to anterior border; moderately then strongly convergent across anterior border; posterior branches moderately divergent. Glabella moderately short, length $55 \pm$ $2 \%$ cranidial length; width $35 \pm 3 \%$ cranidial width, moderately low convexity (sag. and trans.); moderately tapered, width at anterior end $65 \pm 5 \%$ glabellar width; frontal lobe broadly rounded to nearly flat medially. Axial furrow moderately shallow, slightly deeper anteriorly, slightly constricted as S3; preglabellar furrow moderately deep. Lateral glabellar furrows moderate to shallow depth, S1 bifurcated with posterior branch directed towards center of occipital furrow; S2-S4 not bifurcated directed laterally to slightly anterior, S4 very faint or absent. Occipital ring slightly elevated above glabella, moderate convexity; small occipital node; length $17 \pm 2 \%$ glabellar length; posterior margin convex posteriorly, slightly curved medially. S0 gently curved anteriorly, moderately deep and lateral portions arched anteriorly and deeper. Bacculae present adjacent to L1. Frontal area equally divided; length $45 \pm 1 \%$ cranidial length. Preglabellar field slightly convex, moderately downsloping, length $51 \pm 5 \%$ frontal area length. Anterior border nearly slightly concave and level, uniformly curved, uniform length, length $22 \pm 2 \%$ cranidial length. Anterior border furrow very shallow, uniform depth, shallower than axial furrows; false anterior furrow present, less obvious in larger specimens. Fixigena nearly flat, gently sloping upwards, anterior area strongly downsloping laterally; width $68 \pm 9 \%$ glabellar width. Palpebral lobes moderately curved, slightly sloping up, narrow, moderately long, length $40 \pm 4 \%$ glabellar length; anterior margin located opposite L4. Ocular ridge moderate strength, double band absent, slightly curved, directed moderately posterolaterally from glabella at $74 \pm 2^{\circ}$ to axis. Posterior area of fixigena triangular, sharp, nearly $45^{\circ}$ termination; length $38 \pm 9 \%$ (exsag.) glabellar length; width $78 \pm 5 \%$ glabella length.

Librigenae 4.1-12.9 mm long excluding spine ( $\mathrm{N}=2)$; wide, width $\sim 45 \%$ length without spine; lateral margin moderately curved. Genal field moderately convex. Border concave, wider posteriorly, width $\sim 40 \%$ librigenal width; border furrows shallow, deeper posteriorly, and extending down into spine. Librigenal spine long, 100\% librigenal length, slightly curved, flattened.

Rostral plate and hypostome unknown.

Thorax with unknown number of segments. Pleural segments wider than axial ring, directed laterally, directed moderately posterolaterally at moderately developed fulcrum. Anterior and posterior pleural bands strongly convex and uniform in length. Interpleural furrow deep and moderately to fulcrum, then narrowing. Pleural spine moderately short length, termination sharp.
Pygidium 2.7-4.6 mm long $(\mathrm{N}=2)$; subrectangular, length $\sim 70 \%$ width; margin smooth, anterior margin slightly curved posterolaterally, approximately half way to anterolateral corners then strongly directed posterolaterally; anterolateral corners moderately rounded, adjacent to posterior portion of axis; posteromedial notch present, slight; moderately convex (sag.). Axis anterior width $\sim 30 \%$ pygidial width; length $\sim 85 \%$ pygidial length; postaxial ridge absent; slightly tapered, medial width $\sim 85 \%$ anterior width, three axial rings, moderately convex; terminal axial piece moderate size, rounded. Pleural regions moderately curved laterally; pleural furrows and bands poorly developed, except anterior pair. Border weakly defined; border furrow very shallow anteriorly.

Exoskeleton with a fine granular surface; preglabellar area and genal area of librigenae covered with genal caeca.

Remarks.-Resser (1938a) diagnosed this species with the wide anterior border, finely granulated cranidium, genal caeca, and bacculae. Alokistocare natale has these same features and is placed into synonymy. This species is unique for the genus in its possession of bacculae. Amecephalus laticaudum illustrated by Robison et al. (2015, fig. 63 left) is identical to Am. noduliferus from the Lakeview Limestone having a truncated frontal lobe, broad frontal area (trans. and sag.), bacculae adjacent to the base of L1 of the glabella.

In many aspects, Am. noduliferus resembles Palmer's proposed lectotype of Am. piochensis with its wide anterior border (both trans. and sag.), glabellar shape, and sharper termination of the posterior portion of the fixigena, but the latter lacks the bacculae at the base of the glabella. In addition, the illustrated specimen of Am. piochensis by Levi-Setti (1993, pl. 98) from the type area illustrates the same cranidial features as Palmer's lectotype, including the lack of bacculae, but also the librigenal and pygidial features of Am. noduliferus.

Foster (2014, fig. 5.18C) assigned a similar looking specimen from the Half Moon Mine area to Amecephalus althea with its characteristic triangular swelling in the frontal area that separates this species from Am. noduliferus. However, this may indicate that four species of Amecephalus may occur at the type area of Am. piochensis.

Amecephalus notatus (Resser, 1938a)

Figure 32

1938a Alokistocare notatum Resser, p. 8, pl. 1, fig. 43. 1938a Alokistocare nothum Resser, p. 7, pl. 1, figs. 51, 55.

Holotype.-Cranidium USNM 95033 from USNM loc. 37n. 

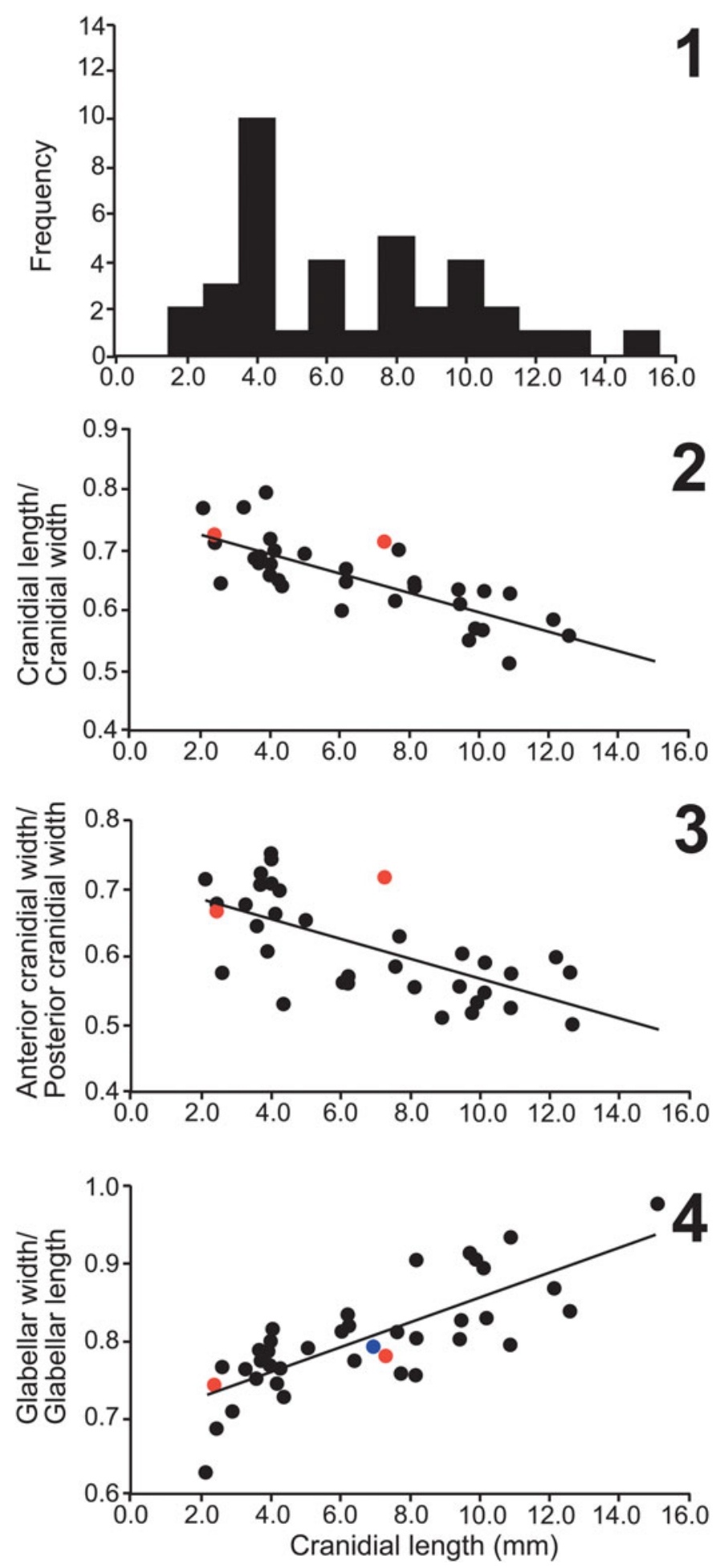

Figure 26. Selected biometrics of Amecephalus normale (Resser, 1938a) from the Lakeview Limestone. Red dots are Resser's type specimens of Alokistocare nactum, and blue dot is Resser's type specimens of Alokistocare normale (only on diagram 4). (1) Cranidial length size distribution of measured specimens; (2) ratio of cranidial length to cranidial width versus cranidial length; $(\mathbf{3})$ ratio anterior cranidial width to posterior cranidial width versus cranidial length; (4) ratio of glabellar width to glabellar length versus cranidial length.

Diagnosis. - Cranidium subtrapezoidal, moderate length frontal area (37 $\pm 2 \%$ cranidial length), slightly divergent anterior facial sutures, anterior border moderately wide (width $72 \pm 5 \%$ cranidial width) and narrow (length $17 \pm 2 \%$ cranidial length), false anterior furrow present; genal caeca well developed on preglabellar field; palpebral lobes slightly sloping upwards; fixigena slightly convex, gently sloping upwards; bacculae absent; covered in moderately coarse granular ornamentation.

Occurrence.-Lakeview Limestone (Ptychagnostus praecurrens Zone), Pend Oreille Lake, Idaho.

Description.-Cranidium length $4.6 \pm 1.0 \mathrm{~mm}$ long $(\mathrm{N}=45)$; subtrapezoidal, anterior border width $72 \pm 5 \%$ cranidial width, cranidial length $66 \pm 4 \%$ cranidial width; moderate convexity (sag. and trans.); anterior margin evenly curved, slightly arched dorsally; posterior margin, excluding occipital ring, slightly curved posterolaterally. Anterior branches of facial sutures slightly divergent to anterior border; strongly convergent across anterior border; posterior branches strongly divergent. Glabella moderately elongated, length $63 \pm 2 \%$ cranidial length; width $33 \pm 2 \%$ cranidial width, moderately tapered, width at anterior end $65 \pm 4 \%$ glabellar width; moderate convexity (sag. and trans.); frontal lobe rounded; length $63 \pm 2 \%$ cranidial length; width $33 \pm 2 \%$ cranidial width. Axial furrow moderately deep, slightly deeper posteriorly, slightly constricted at S3; preglabellar furrow moderately shallow. Lateral glabellar furrows moderately deep, S1 bifurcated, posterior branch directed to center of occipital furrow; S2-S4 not bifurcated, directed laterally to slightly anterior, S4 very faint or absent. Occipital ring slightly elevated above glabella, moderate convexity; small occipital node; length $20 \pm 2 \%$ glabellar length; posterior margin convex posteriorly, slightly curved medially. S0 gently curves anteriorly, moderately deep and lateral portions arched anteriorly and deeper. Bacculae absent. Frontal area nearly equally divided; length $37 \pm 2 \%$ cranidial length. Preglabellar field slightly convex, moderately downsloping, length $54 \pm 8 \%$ frontal area length. Anterior border very slightly concave and level, uniform curvature, slightly tapering laterally, length 17 $\pm 2 \%$ cranidial length. Anterior border furrow shallow to moderately deep laterally; shallower than axial furrows; false anterior furrow well developed in larger specimens, fainter is smaller specimens, tapering laterally, absent at lateral margins of cranidium. Fixigena slightly convex, level, anterior area moderately downsloping; width $60 \pm 5 \%$ glabellar width. Palpebral lobes moderately curved, slightly sloping up, narrow, moderately long, length $45 \pm 3 \%$ glabellar length; anterior margin located opposite L3. Ocular ridge moderate strength, consists of two faint bands, slightly curved, directed moderately posterolaterally from glabella at $76 \pm 4^{\circ}$ to axis. Posterior area of fixigena strap like, sharp, nearly $90^{\circ}$ termination; length 30 $\pm 3 \%$ glabellar length; width $79 \pm 6 \%$ glabella length .

Cranidium with a moderately coarse granular surface; preglabellar area and genal area of fixigenae covered with genal caeca, strongly developed on internal molds.

Rostral plate, hypostome, librigena, thorax, and pygidium unknown.

Remarks.-Amecephalus notatus is only known from rare isolated cranidia. Pygidia and librigena found with this species 
Journal of Paleontology 94(S79):1-49
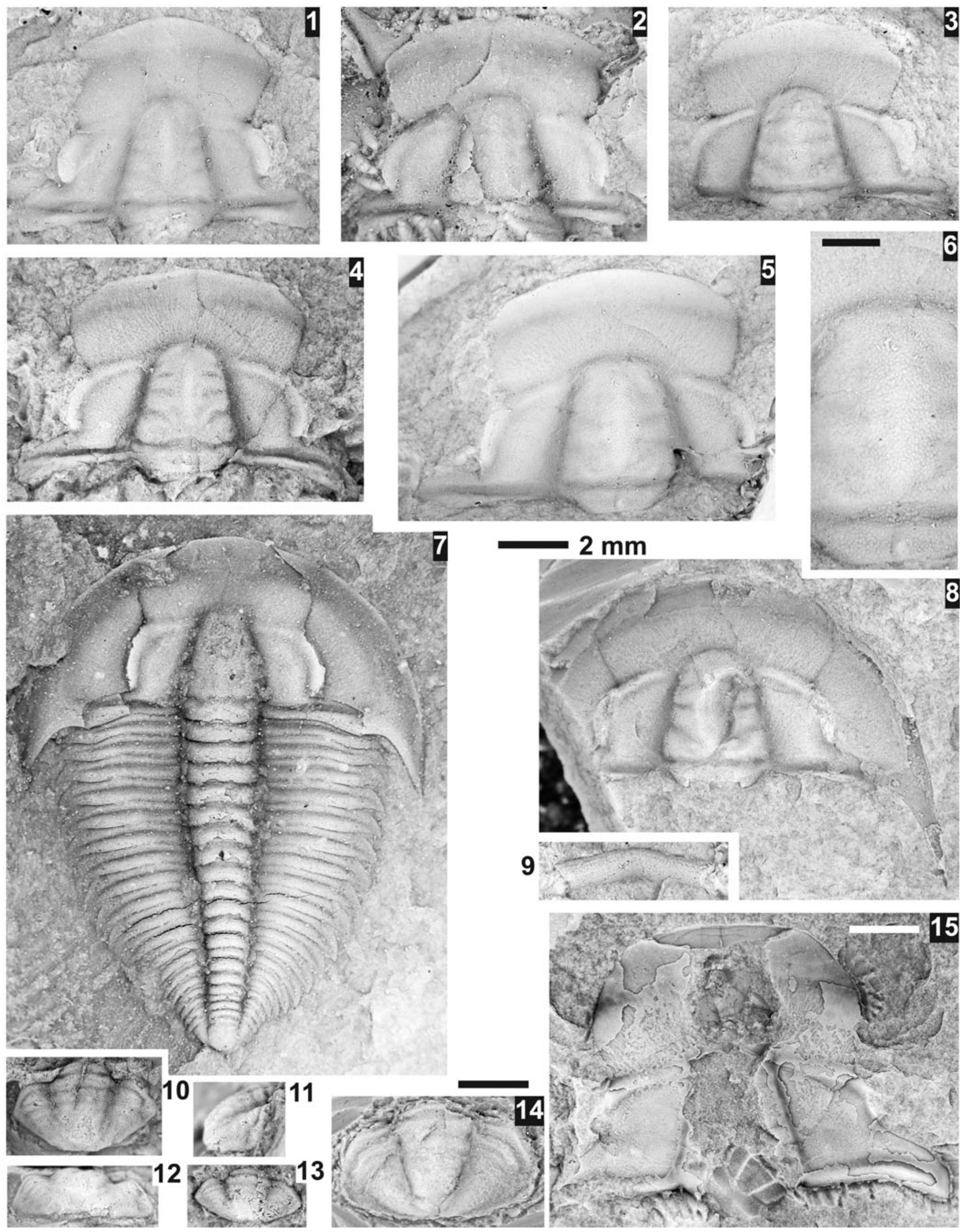

\section{$2 \mathrm{~mm}$}
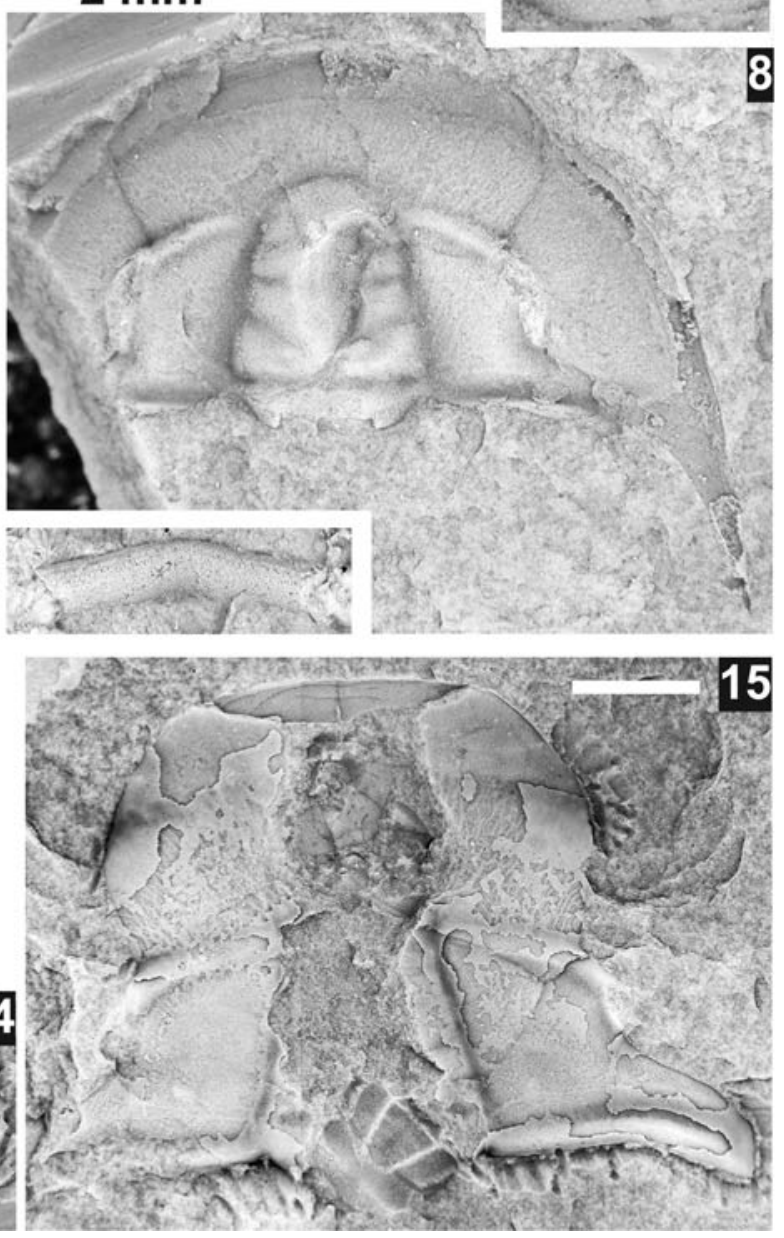
Figure 27. Amecephalus piochensis (Walcott, 1886), from the Glossopleura walcotti Zone, Chisholm Formation, Half Moon Mine, Pioche, Nevada. All specimens from USNM loc. 44284 and uses the $2 \mathrm{~mm}$ scale bar unless otherwise mentioned. (1) Latex cast of cranidium USNM 724207; (2) latex cast of cranidium USNM 72404; (3) latex cast of cranidium USNM 72405; (4) exfoliated of cranidium USNM 724206; (5, 6) latex cast of cranidium USNM 724207, scale bar in close-up is $1 \mathrm{~mm}$; (7) latex cast of complete shield USNM 770862 (USNM loc. 44285); (8) exfoliated cephalon USNM 724209; (9) latex cast of rostral plate USNM 724210; (10-12) exfoliated pygidium USNM 724211, dorsal, lateral, and posterior view; (13) exfoliated pygidium USNM 724212; (14) large exfoliated pygidium USNM 770861, black bar is $4 \mathrm{~mm}$; (15) large exfoliated broken cranidium USNM 770860, white bar is $5 \mathrm{~mm}$.
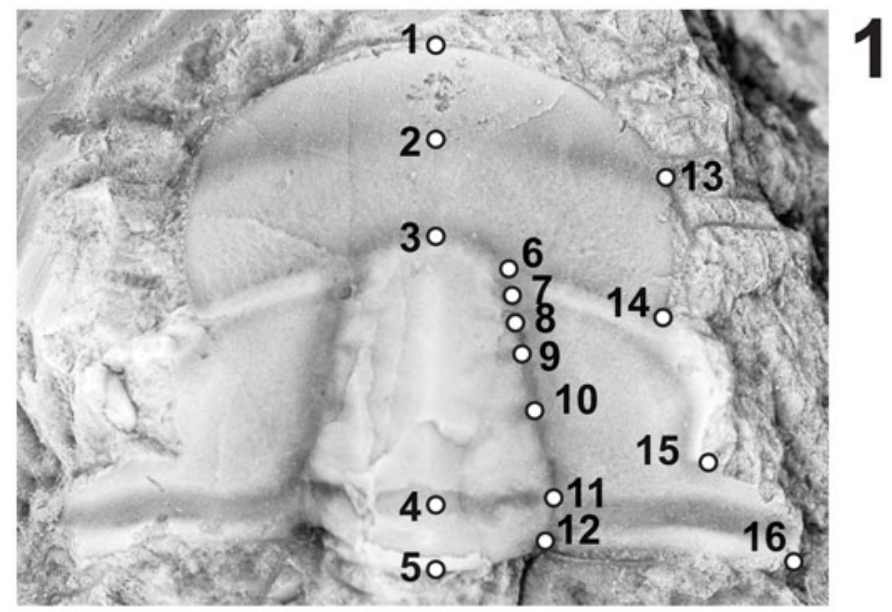

1

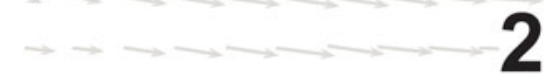

2・

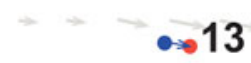

$3^{\bullet}$
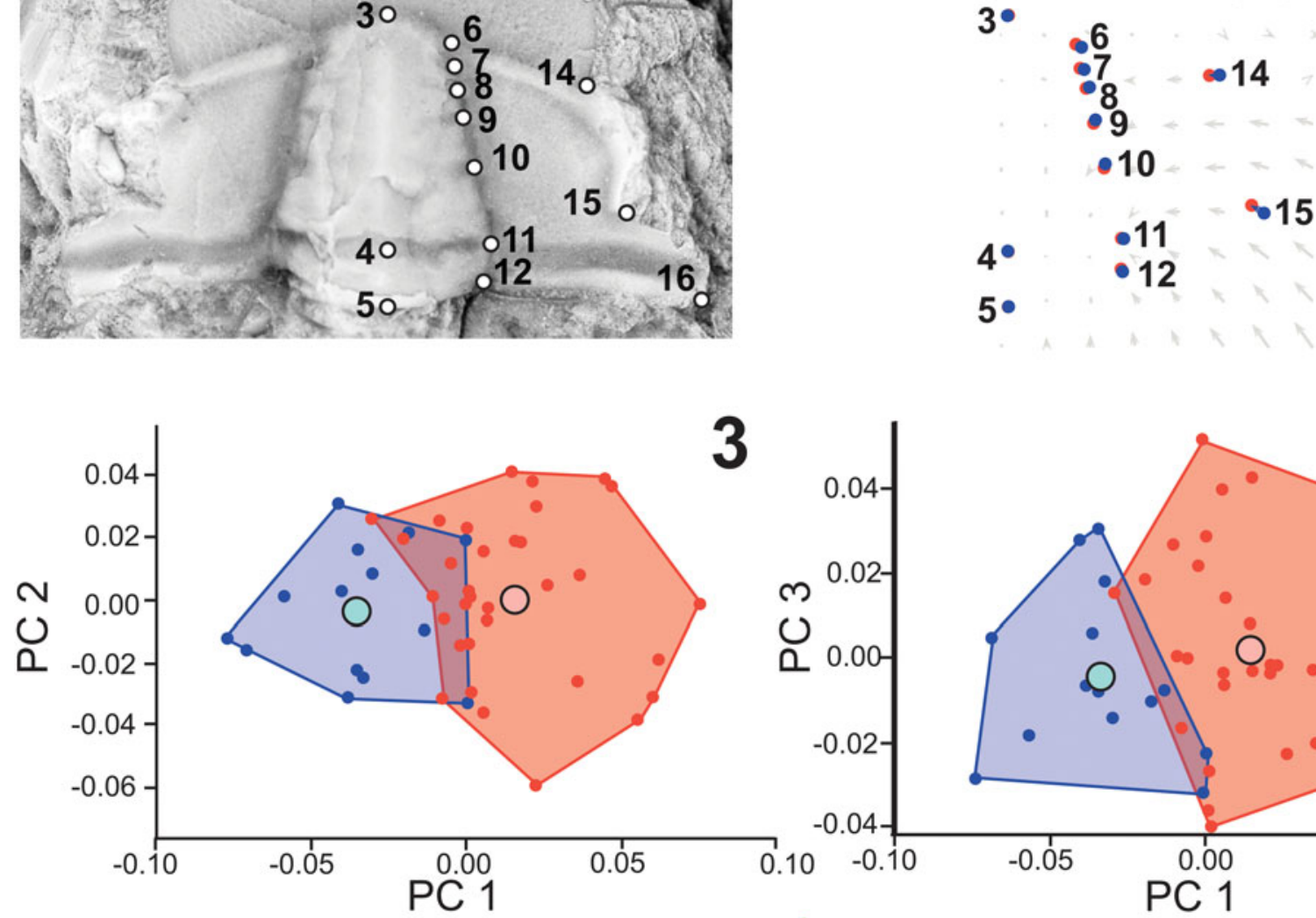

Am. normale

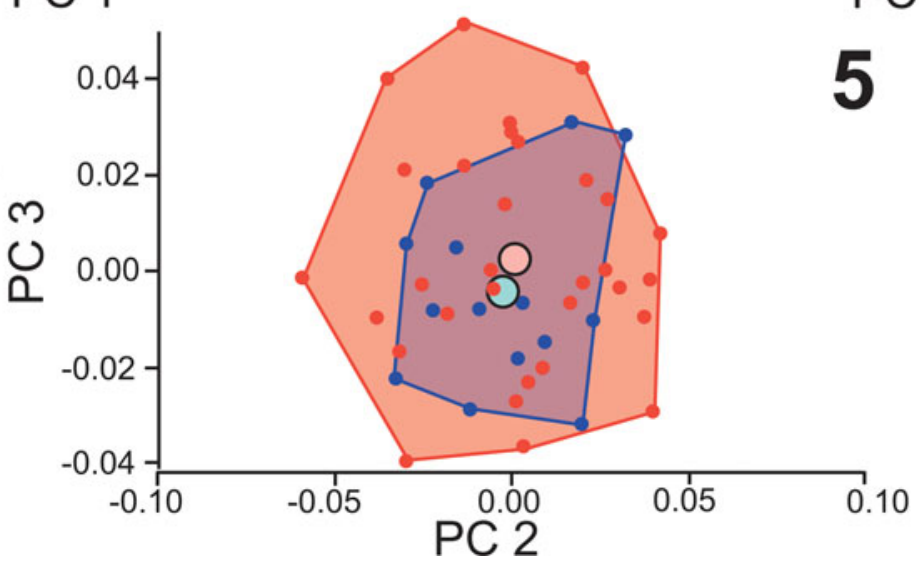

Figure 28. Landmark results in the comparison Amecephalus normale (Resser, 1938a; blue) and Amecephalus piochensis (Walcott, 1886; red) of similar size. (1) Location of landmarks used in the study illustrated on A. normale (USNM 723948). (2) Mean location of landmarks and quiver plot showing the movements of landmarks of A. normale to A. piochensis. (3-5) PCA plots comparing the two species; large dots represent species means. 

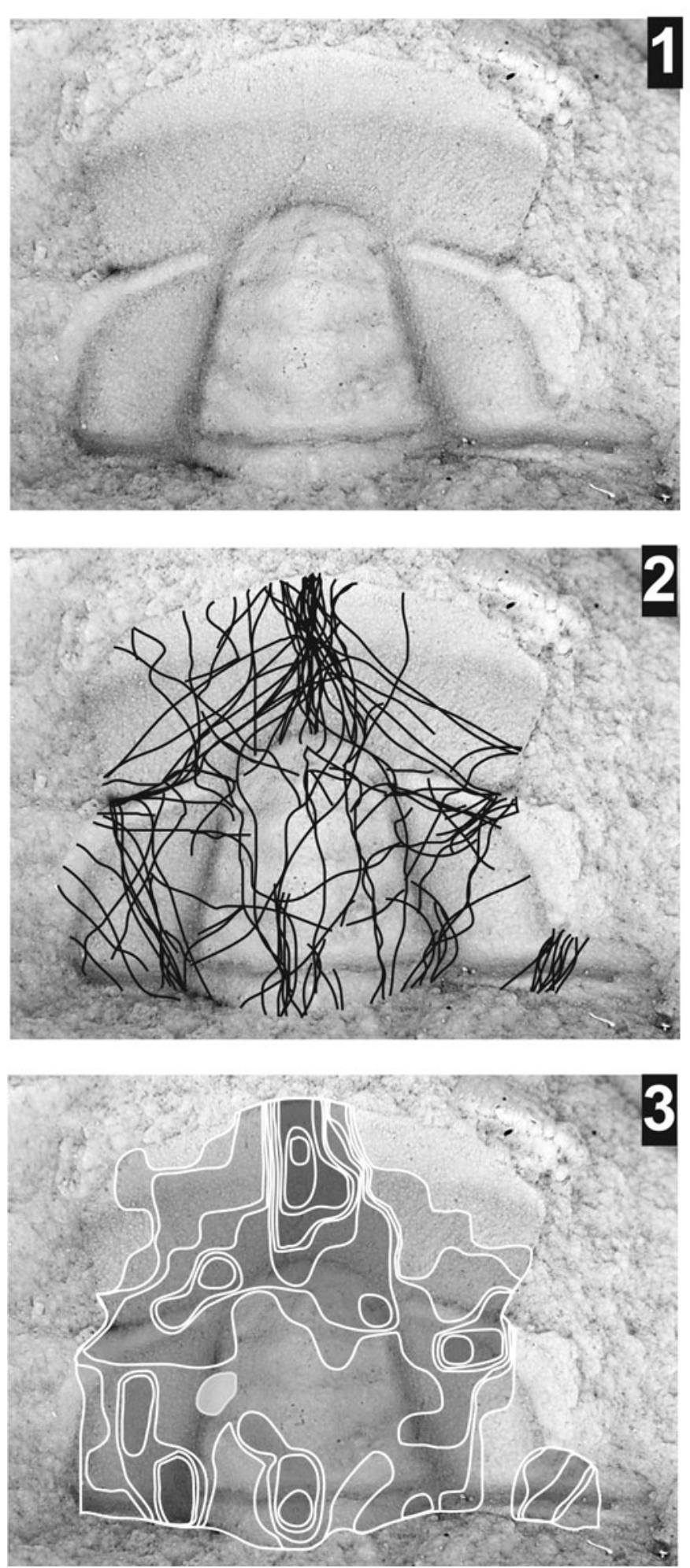

Figure 29. Compactional cracks occurring on specimens of Amecephalus piochensis (Walcott, 1886) based on 35 cranidia. (1) Specimen USNM 724206 used as base for crack distribution. (2) Distribution of cracks superimposed on specimen USNM 724206. (3) Density of cracks based on counts of cracks in a box grid; darker colors indicate more cracks, contours based on two or more cracks within a box and contour interval is two cracks (e.g., 2-3, 3-4, etc.).

do not contain the moderately coarse granular ornament and are here assigned to Am. normale.
"Alokistocare" nothum is placed in to Am. notatus and considered the same given their overall cranidial morphology, although the two type specimens plot slightly away from $\mathrm{Am}$. notatus in the PCA (Fig. 23). Given that the two forms occur in the same horizon, this difference is not considered significant. The holotype of Amecephalus notatus is larger and better preserved than the two specimens of "Al." nothum, even though the latter species was originally described a page before the former (ICZN Article 24.2, "First Reviser" can choose which species name to use as senior synonym regardless of the order of description within a paper; see International Commission on Zoological Nomenclature, 1999). Amecephalus notatus differs from Am. normale in having divergent anterior branches of the facial suture and a narrower (tr.) anterior border and fixigena. Resser diagnosed this species with a medium swelling in the anterior border that causes the border to be uneven in width.

\section{Genus Elrathina Resser, 1937}

Type species.—Conocephalites cordillerae Rominger, 1887, Stephen Formation, British Columbia, Canada.

Diagnosis.-Cranidium with a glabella with subparallel sides, shallow lateral glabellar furrows, S1 with a long and strongly backward directed branch, S2-S4 short and simple; palpebral lobes small, located anterior to the cranidium midlength, defined adaxially by a shallow and incompletely developed palpebral furrow; ocular ridges that curve distinctly backward; fixigenae gently convex, $\geq 50 \%$ wider (trans.) than glabellar width; convex anterior border wide (trans.); facial sutures with anterior branches subparallel close to the palpebral lobes and then convergent towards the anterior border, the posterior branches diverging $\sim 45^{\circ}$ to exsagittal line. Librigenae with a rounded posterolateral corner or a short genal spine. Thorax composed of subequal segments with only small pleural spines. Pygidium small, sublenticular, with an entire, nearly uniformly curved posterior margin; axis relatively broad and long pygidial axis; pleurae without a consistent segmentation; border and border furrow obscure.

Remarks.-Geyer and Peel (2017, p. 272) provided an informal diagnosis of Elrathina and a review of Elrathina species. The above diagnosis is derived from this informal diagnosis (also see Sundberg, 2018).

\section{Elrathina idahoensis (Resser, 1938a)} Figure 33

1938a Elrathia idahoensis Resser, p. 8, pl. 1, figs. 36-40.

Holotype.-Cranidium USNM 95034 from USNM loc. 37n.

Paratypes.-Specimens USNM 95034a-e from USNM loc. 37 n.

Occurrence.-Lakeview Limestone (Ptychagnostus praecurrens Zone), Pend Oreille Lake, Idaho. 

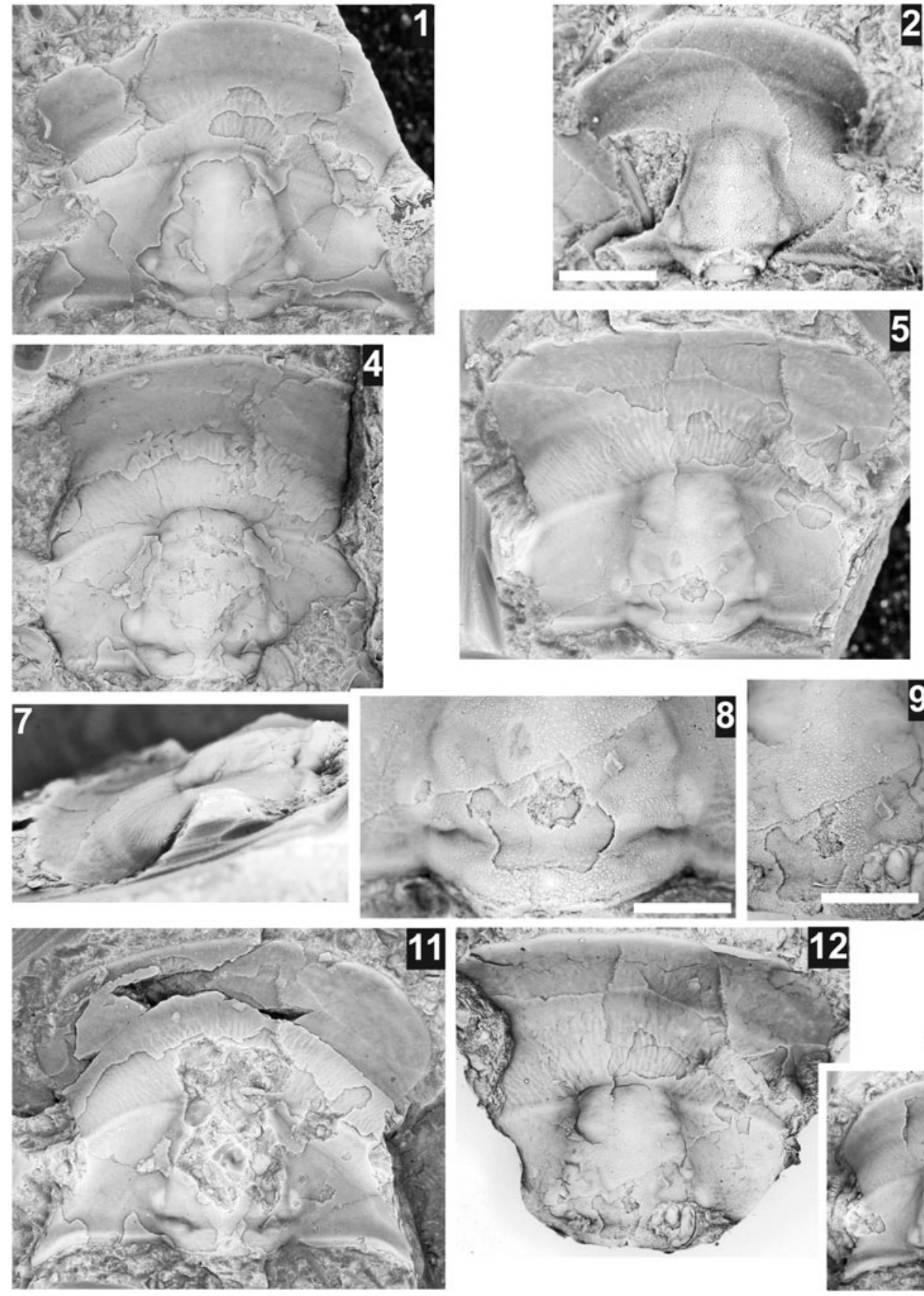
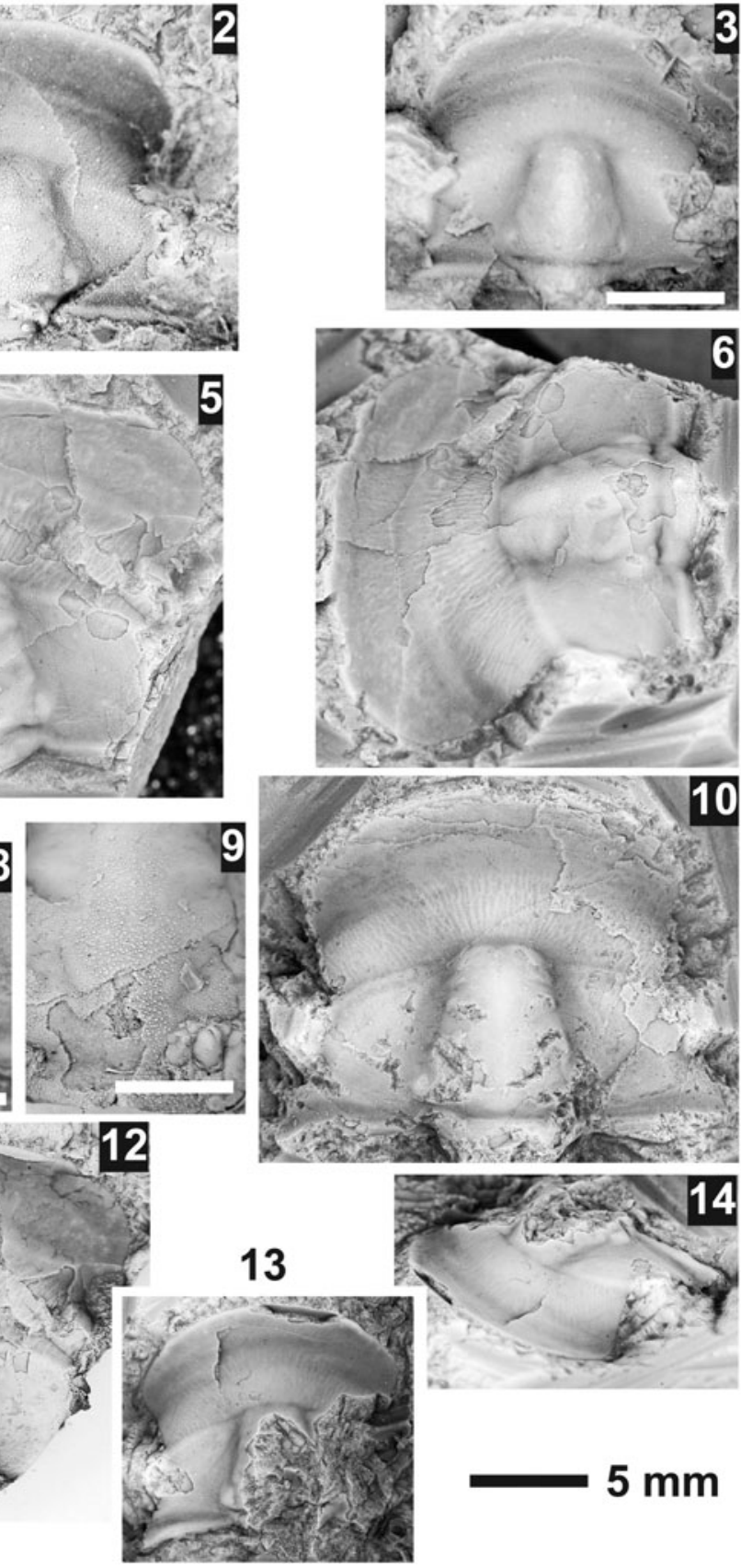

Figure 30. Amecephalus noduliferus (Resser, 1938a), from the Ptychagnostus praecurrens Zone, Lakeview Limestone, Pend Oreille Lake, Idaho. (1) Resser's holotype of Alokistocare noduliferum mostly exfoliated cranidium USNM 95029 (USNM loc. 37n); (2) Resser's paratype of Alokistocare noduliferum testate cranidium USNM 95029a (USNM loc. 37n), white scale bar $=2 \mathrm{~mm}$; (3) Resser's holotype of Alokistocare natale, testate cranidium USNM 95030 (USNM loc. 37n), white scale bar $=2 \mathrm{~mm} ;(\mathbf{4 - 8})$ partially testate cranidium USNM 723936 (USNM loc. 44282), (4) latex cast, (5-7) dorsal, oblique, and lateral views, (8) close-up of the base of the glabella and occipital ring, white scale bar $=1 \mathrm{~mm} ;(\mathbf{9 , 1 1}, \mathbf{1 2})$ mostly testate cranidium USNM 723935 (USNM loc. 44282), (9) close-up of the base of the glabella, white scale bar $=1 \mathrm{~mm}$ and $(\mathbf{1 1}, \mathbf{1 2})$ broken cranidium and latex cast; $(\mathbf{1 0})$ exfoliated cranidium USNM 723939 (USNM loc. 44279); (13, 14) mostly testate fragmented cranidium USNM 723941 (USNM loc. 44280), dorsal and oblique views.

Diagnosis. - Cranidium with subparallel to slightly tapering glabella $(79 \pm 5 \%$ glabellar width) with a rounded to slightly flattened front; palpebral lobes small $(25 \pm 3 \%$ glabellar length), but not minute, located medially on cranidium; ocular ridges with gentle curvature; anterior border moderately narrow (length $11 \pm 2 \%$ cranidial length), without medial swelling; preglabellar field of relatively long (length $15 \pm 2 \%$ cranidial length); librigenae with moderately short genal spine $(30 \pm 12 \%$ librigenal length); geniculation of thoracic pleurae abaxially to pleural mid-length; pygidium subtriangular, posteromedial notch moderately developed; pygidial axis broad (width $43 \pm 5 \%$ pygidial width), with one to two rings, its posterior end rounded without slightly inflated bulbs, reaching almost to the posterior margin (length $90 \pm 3 \%$ pygidial length); pygidial pleurae with one furrow. 


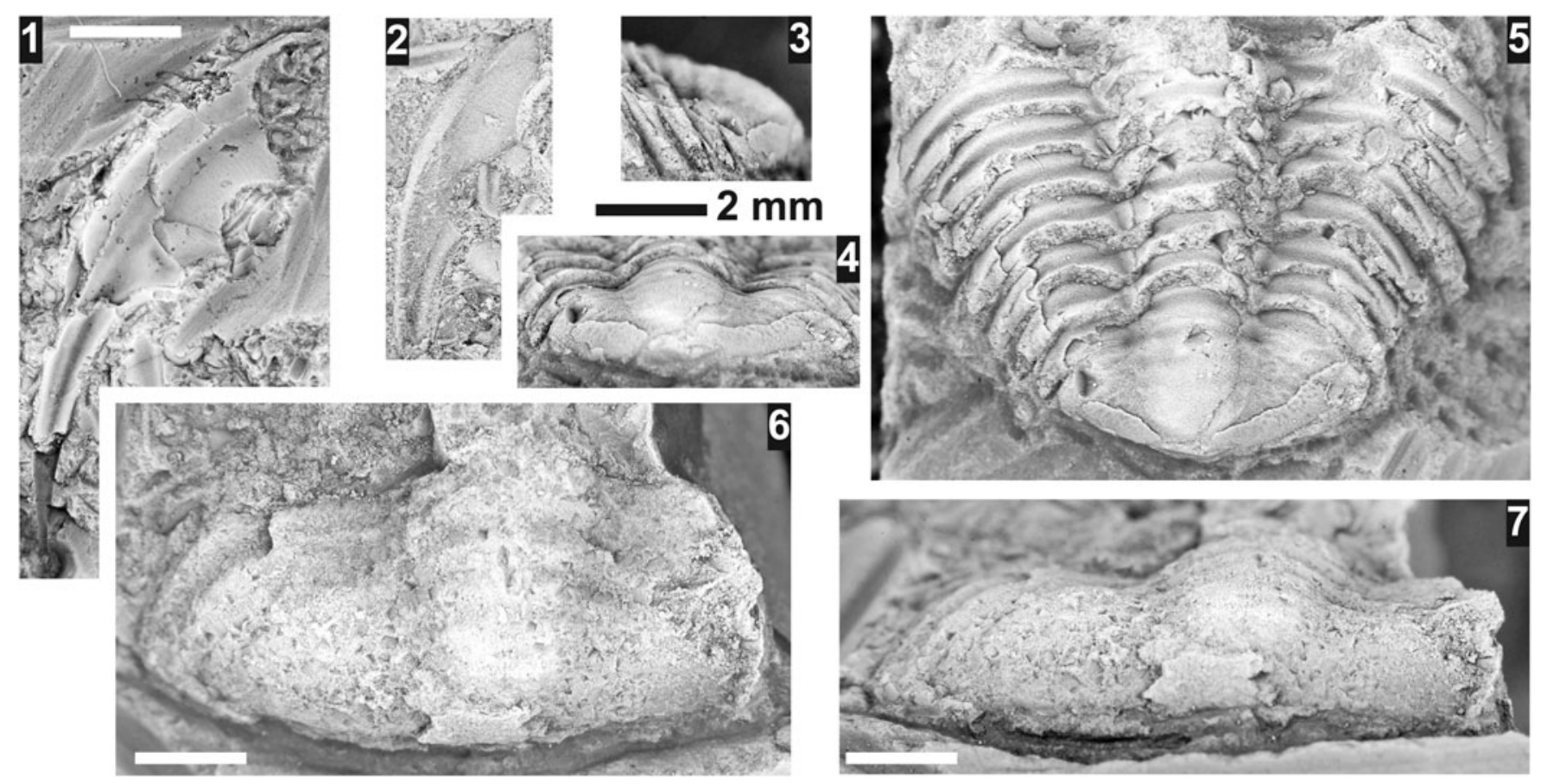

Figure 31. Amecephalus noduliferus (Resser, 1938a), from the Ptychagnostus praecurrens Zone, Lakeview Limestone, Pend Oreille Lake, Idaho. White scale bars $=5 \mathrm{~mm}$. (1) Mostly exfoliated librigena USNM 723940 (USNM loc. 44280); (2) exfoliated librigena USNM 723934 (USNM loc. 44282); (3-5) pygidium and partial thorax USNM 723937 (USNM loc. 44279), lateral, posterior, and dorsal views; (6, 7) exfoliated pygidium USNM 723938 (USNM loc. 44279), dorsal and posterior views.

Description.-Cranidium $\quad 5.1 \pm 2.0 \quad \mathrm{~mm}$ long $\quad(\mathrm{N}=31)$ subtrapezoidal, moderately low convexity (sag. and trans.); anterior margin slightly and evenly curved, slightly arched dorsally; posterior margin, excluding occipital ring, nearly straight, directed slightly posterolaterally. Anterior branches of facial sutures slightly convergent $17 \pm 7^{\circ}$ to anterior border, more convergent to anterior margin; posterior branches moderately divergent $53 \pm 4^{\circ}$. Glabella moderately elongated, slightly tapered, width at anterior end $79 \pm 5 \%$ glabellar width (K2); moderately convex (sag. and trans.); frontal lobe bluntly rounded; length $74 \pm 3 \%$ cranidial length; width $33 \pm 2 \%$ cranidial width. Axial furrows moderately deep, straight and convergent towards anterior; preglabellar furrow moderately shallow. Lateral glabellar furrows very shallow, S1 bifurcated directed posteriorly, S2 slightly posterior, S3 and S4 faint or absent. Occipital ring not elevated above glabella, moderately convex; moderate occipital spine; length $19 \pm 2 \%$ glabellar length; posterior margin convex posteriorly, evenly curved. S0 straight to slightly curved anteriorly medially in larger specimens; and moderately deep, shallower medially. Frontal area subequally divided; length $25 \pm 3 \%$ cranidial length. Preglabellar field very slightly convex, slightly downsloping, length $15 \pm 2 \%$ cranidial length, $57 \pm 6 \%$ frontal area length. Anterior border moderately convex, level, slightly tapering laterally, no medial inbend, length $11 \pm 2 \%$ cranidial length. Anterior border furrow moderate width and shallow, shallower medially, shallower than axial furrows. Fixigena slightly convex, level, anterior area slightly downsloping, lateral portions more strongly downsloping; width $59 \pm 6 \%$ glabellar width (K2). Palpebral lobes nearly straight, slightly upturned, moderately narrow and moderately short, length $25 \pm 3 \%$ glabellar length; anterior margin located opposite frontal lobe. Ocular ridge faint to very faint, straight to slightly arched, directed slightly posterolaterally from glabella at $80 \pm 3^{\circ}$ to axis. Posterior area of fixigena triangular, terminated with rounded corner; length $72 \pm$ $5 \%$ glabellar length; width $46 \pm 3 \%$ glabella length

Librigenae $4.8 \pm 1.1 \mathrm{~mm}$ long $(\mathrm{N}=6)$; moderately wide, width $34 \pm 2 \%$ length without spine; lateral margin moderately curved. Genal field slightly convex. Border slightly convex, uniform in width, width $29 \pm 5 \%$ librigenal width; border furrows shallow. Librigenal spine moderately short, $30 \pm 12 \%$ librigenal length, nearly straight; shorter and slightly deflected laterally in smaller specimens.

Rostral plate and hypostome unknown.

Thorax with at least 17 segments, tapering towards small pygidium. Pleural segments nearly as wide as axial ring, directed laterally, directed moderately posterolaterally at moderately developed fulcrum. Anterior pleural band moderately convex and uniform in length, posterior band moderately convex and narrowing to fulcrum, then uniform length. Interpleural furrow moderately deep and widening to fulcrum, then narrowing. Pleural spine short, termination pointed to sharply rounded.

Pygidium 0.9-1.8 $\mathrm{mm}$ long $(\mathrm{N}=6)$; subtriangular, length $40 \pm 2 \%$ width; margin smooth, anterior margin distally slightly to moderately curved posterolaterally; anterolateral corners rounded, adjacent to anterior portion of axis; posteromedial notch moderately developed; moderately convex (sag.). Axis slightly tapered mid width $85 \pm 6 \%$ anterior width, anterior width $45 \pm 4 \%$ pygidial width; length $91 \pm 3 \%$ pygidial length, postaxial ridge absent; one or two axial rings, moderately convex; terminal axial piece moderate size(?), rounded; axial ring furrows effaced. Pleural regions nearly flat, level; anterior 

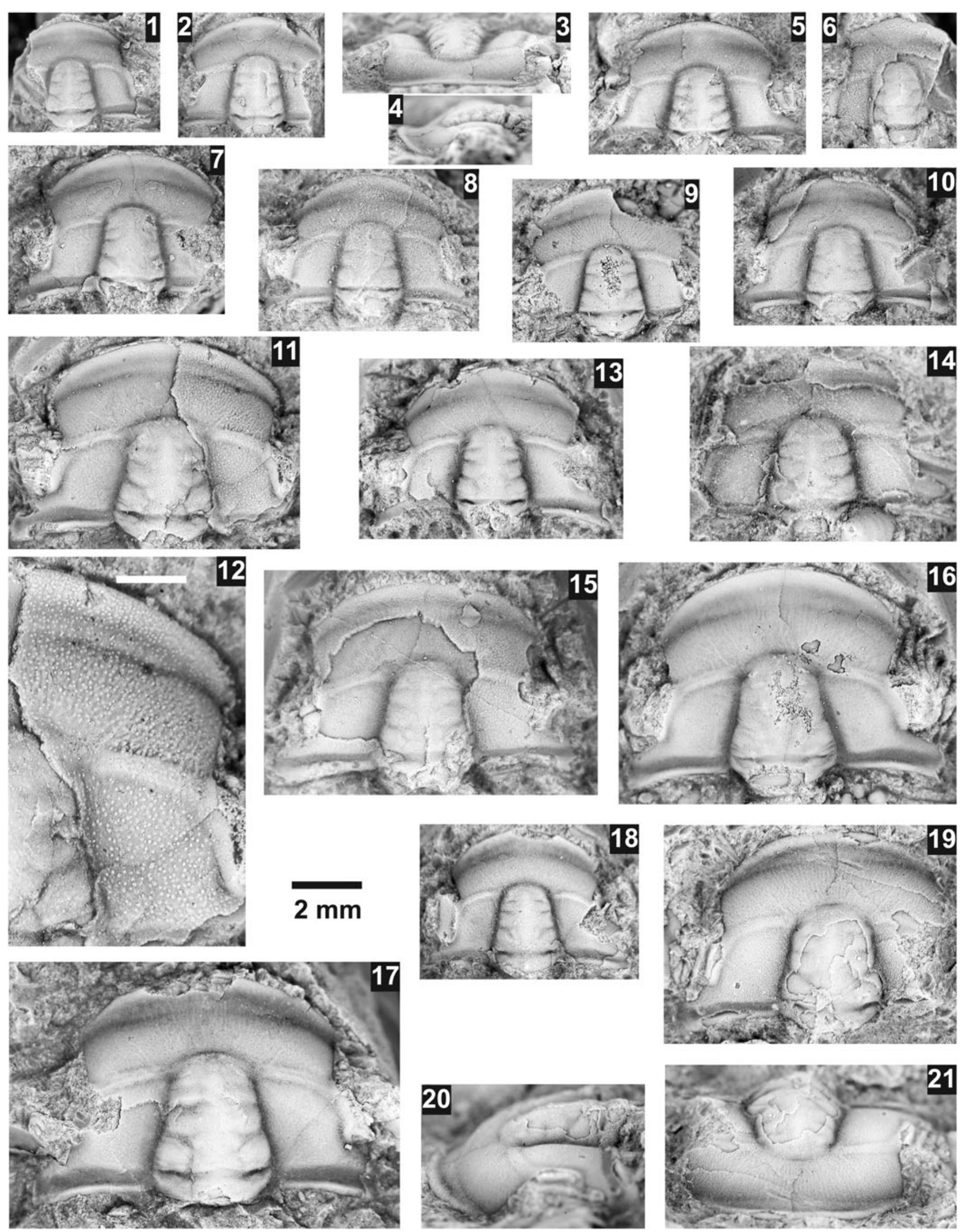


\begin{abstract}
Figure 32. Amecephalus notatus (Resser, 1938a), from the Ptychagnostus praecurrens Zone, Lakeview Limestone, Pend Oreille Lake, Idaho. (1) Mostly exfoliated cranidium USNM 723978 (USNM loc. 44282); (2) exfoliated cranidium USNM 723975 (USNM loc. 44280); (3-5) Resser's holotype of Alokistocare nothum, exfoliated cranidium USNM 95031 (USNM loc. 37n), anterior, lateral, and dorsal view; (6) partially testate cranidium USNM 723976 (USNM loc. 44282); (7) exfoliated cranidium USNM 723972 (USNM loc. 44280); (8) exfoliated cranidium USNM 723973 (USNM loc. 44280); (9) exfoliated cranidium USNM 723971 (USNM loc. 44280); (10) exfoliated cranidium USNM 723974 (USNM loc. 44280); (11, 12) partially testate cranidium USNM 723970 (USNM loc. 44280 ), white bar in close-up is $1 \mathrm{~mm}$; (13) mostly exfoliated cranidium USNM 723969 (USNM loc. 44280). (14) Resser's paratype of Alokistocare nothum, mostly exfoliated cranidium USNM 95031a (USNM loc. 37n), but showing granular ornamentation on the anterior border; (15) partially testate cranidium USNM 723977 (USNM loc. 44282 ); (16) exfoliated cranidium USNM 723968 (USNM loc. 44280); (17) exfoliated cranidium USNM 723979 (USNM loc. 44282); (18) exfoliated cranidium USNM 723967 (USNM loc. 44280). (19-21) Resser's holotype of Alokistocare notatum, mostly testate cranidium USNM 95033 (USNM loc. 37n), dorsal, lateral, and anterior views.
\end{abstract}

pleural furrow wide and very shallow, extending to border(?); no additional pleural furrows. Border poorly defined, narrow, wider at anterolateral corners, level; absent at posterior margin; border furrow absent.

Faint, fine granules on glabella, occipital ring, librigenae, axial rings, and thoracic pleura. Faint genal caeca on preglabellar regions of larger specimens.

Remarks.-Resser (1938a, p. 8) characterized this common species by "a fullness of all parts of the cranidium..." due to the moderately convex nature of the glabella and anterior border. Elrathia idahoensis was re-assigned to Elrathina Walcott, 1924 by Robison (1964, p. 541), which is maintained here due to the nearly parallel sided glabella; anteriorly placed, small palpebral lobes; convergent anterior branches of the facial suture; and exsagittally long posterior area of the fixigena. This species also fits the concept of Elrathina (Geyer and Peel, 2017; Sundberg, 2018), except for the relatively long librigenal spine. Nearly all of the specimens have been compressed to some extent, which is evident from the fractures crossing the cranidia. In many instances, this compression could have reduced the convexity of the glabella and anterior border. Almost all specimens have an occipital node, with one specimen (Fig. 33.14-33.16) showing the recurved spine.

Small changes occur during the ontogeny of later meraspids $(>1.5 \mathrm{~mm})$ to holaspids. In general, cranidium becomes more rectangular, glabellar width to length ratio increases, and glabellar taper increases.

This species is similar to E. hera Geyer and Peel, 2017 in overall cranidial shape, but differs in the a longer preglabellar area and a wider (trans.) anterior border; librigenae with a slightly longer genal spine; and a pygidium with a broader (trans.) axis.

Elrathina cf. idahoensis (Resser, 1938a)

Figure 34

Occurrence.-Lakeview $\quad$ Limestone
praecurrens Zone), Pend Oreille Lake, Idaho.

Remarks. - The rare specimens assigned to this species are mostly small meraspids and are similar to the smaller meraspids of E. idahoensis. Differences between the two species are the former having a cranidium with a narrower (trans.) anterior border, shorter (sag.) preglabellar area; librigenae with very minute thorn like genal spine (Fig. 34.9, 34.10); and pygidia with better defined pleural, interpleural, and axial ring furrows. These specimens are placed into open nomenclature due to the lack of larger and additional specimens.

Geyer and Peel (2017, p. 272) pointed out that the figured specimens of E. spencei (Resser, 1939a) probably represent three different species, which is agreed to herein. The holotype of the species (Resser, 1939a, pl. 5, fig. 15) is very similar to E. cf. idahoensis, but differs from the latter in a more tapered glabella, similar to a single specimen of the latter (Fig. 34.7), and an indentation of the posterior pygidia margin. However, the indentation of the pygidium may be the result of compaction, which enhanced the arch of the posterior margin seen in the pygidia assigned to E. cf. idahoensis (Fig. 34.12, 34.13). Resser's material of the Spence Shale needs to be restudied to determine the morphological characters of Elrathina spencei and the similar Elrathia rara Resser, 1939a and Clappaspis lanata Resser, 1939a and determine their taxonomic affinity.

\section{Family Utiidae Kobayashi, 1935 Genus Utia Walcott, 1924}

Type species.-Utia curio Walcott, 1924, from the Spence Shale, Bear River Range, Idaho, by original designation.

Diagnosis.-Cranidium subrectangular with strong sagittal convexity. Glabella moderately elongated ranging from 65$70 \%$ of cranidial length, subparallel, tapered from S0 to S2 then nearly parallel, lateral glabellar furrows shallow to very shallow medially; axial furrows deepest anteriorly, preglabellar furrow moderately deep. S0 moderately deep. Frontal area and adjacent portion of fixigena convex, level in posterior portion, anterior portion directed strongly dorsal. Anterior border slightly tapered distally, positioned nearly vertical, no medial inbend, anterior border furrow shallow laterally to very shallow medially. Fixigena with intraocular region wide from $75-80 \%$ glabellar width, slightly depressed to flat, level; anterior region moderately downsloping. Palpebral lobes moderately long at $40-50 \%$ glabellar length, anterior set adjacent to L3, extending to or posterior of S1, slightly curved. Posterior area of fixigena triangular with sharp termination, border uniform length (exsag.); border furrow deep, extends to suture. Anterior branches of facial sutures convergent to anterior border; posterior branches strongly divergent to posterior border furrow.

Remarks. - The diagnosis is based on Walcott (1925, p. 119121), and features seen in Utia debra n. sp. Known mainly from cranidia, this genus is distinct with its strongly convexity 

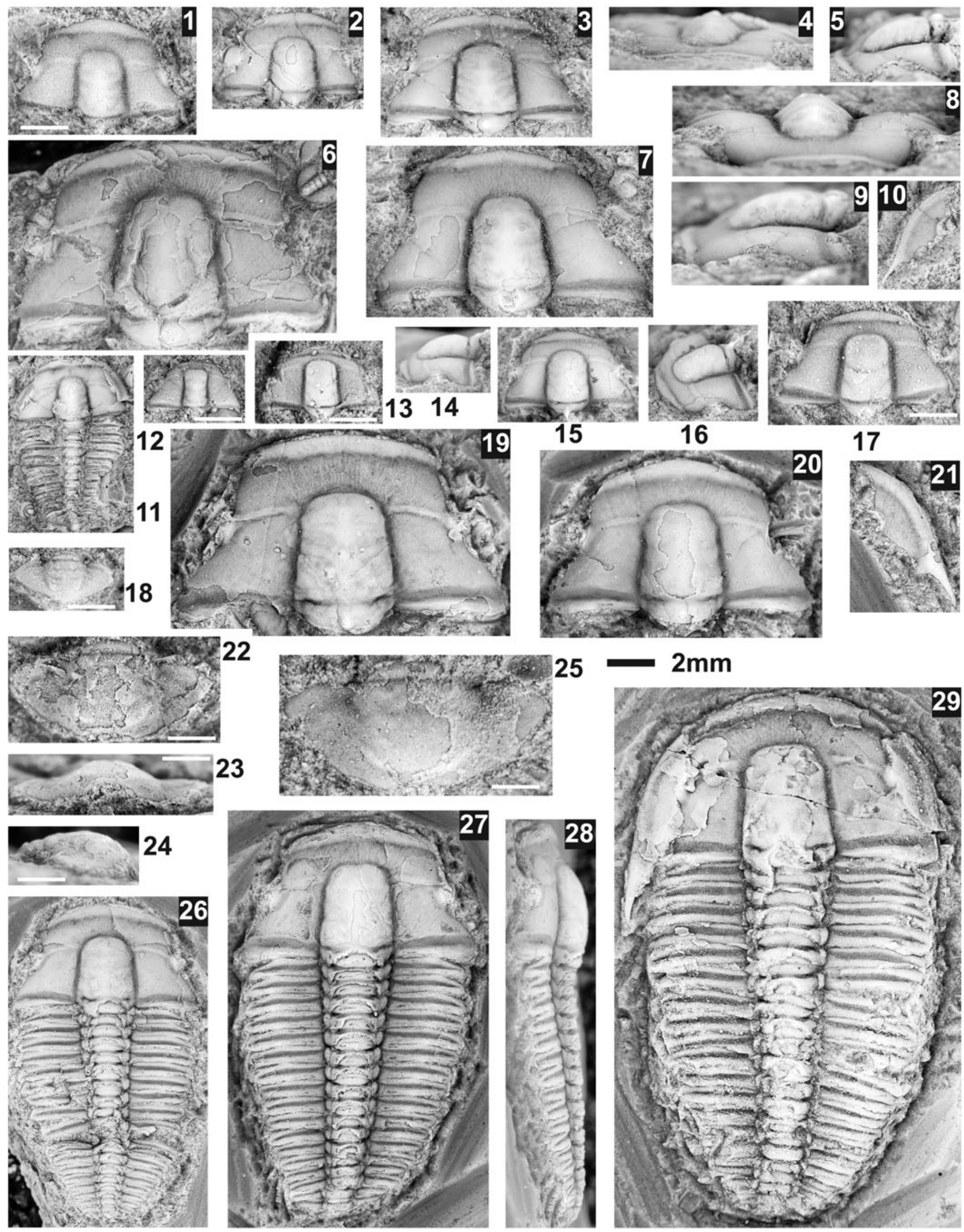

22

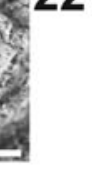

23

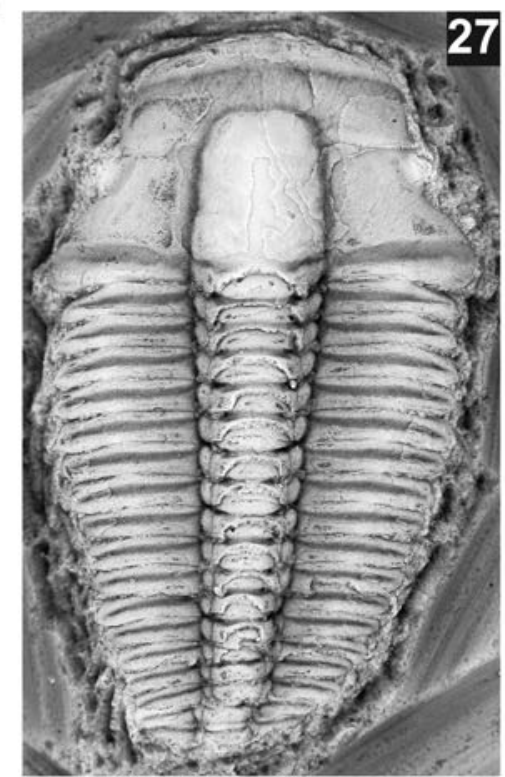

\section{$2 \mathrm{~mm}$}

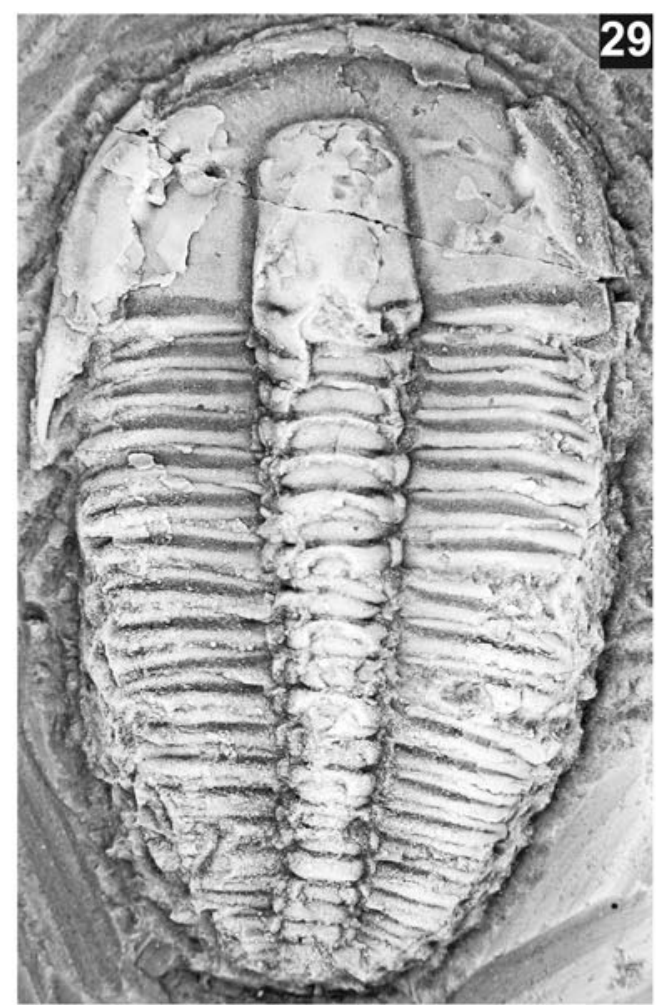


Figure 33. Elrathina idahoensis (Resser, 1938a), from the Ptychagnostus praecurrens Zone, Lakeview Limestone, Pend Oreille Lake, Idaho. White bars are $1 \mathrm{~mm}$ scale, all others use the $2 \mathrm{~mm}$ scale. (1-9, 11) Resser's type specimens from USNM loc. 37n. (1) Testate paratype cranidium USNM 95034a; (2) mostly testate holotype cranidium USNM 95034; (3-5) mostly testate paratype cranidium USNM 95034c, dorsal, lateral, and anterior views; (6) partially testate paratype cranidium USNM 95034e; (7-9) mostly testate paratype cranidium USNM 95034d, dorsal, anterior and lateral views; (11) partially exfoliated paratype shield USNM 95034b. (10, 12-29) Additional topotype specimens; (10) mostly exfoliated librigena USNM 724016 (USNM loc. 44282); (12) exfoliated small cranidium USNM 724014 (USNM loc. 44279); (13) mostly exfoliated small cranidium USNM 724024 (USNM loc. 44280); (14-16) mostly exfoliated cranidium USNM 724013 (USNM loc. 44279) illustrating recurved occipital spine in lateral, dorsal, and oblique views; (17) exfoliated small cranidium USNM 724021 (USNM loc. 44280); (18) mostly exfoliated pygidium USNM 724015 (USNM loc. 44282); (19) mostly testate cranidium USNM 724020 (USNM loc. 44280); (20) mostly testate cranidium USNM 724018 (USNM loc. 44282); (21) mostly exfoliated librigena USNM 724017 (USNM loc. 44282); (22-24) partially testate pygidium USNM 724023 (USNM loc. 44280), dorsal, posterior, and lateral views; (25) mostly exfoliated librigena USNM 724022 (USNM loc. 44280); (26) mostly exfoliated shield USNM 724012 (USNM loc. 44279); (27, 28) partially testate shield USNM 724011 (USNM loc. 44279), dorsal and lateral views; (29) mostly exfoliated shield USNM 724019 (USNM loc. 44280).

of the frontal area where the anterior portion is nearly vertical. Yuknessaspis Rasetti, 1951 from the higher Ehmaniella Zone (Sundberg, 1994) are similar in the deep glabellar furrows and strongly convexity of the frontal area, but generally has a more tapered glabella, broadly rounded termination to the posterolateral portion of the fixigena, and more pronounced anterior border furrow.

\section{Utia debra new species}

Figure 35

1938a Utia curio; Resser, p. 9, pl. 1, figs. 19, 20 (not fig. $21=$ Oryctocara).

1939a Utia curio; Resser, p. 21, pl. 2, fig. 3.

Holotype.-Cranidium USNM 724166 from USNM loc. 44280.

Paratypes.-USNM 95041 and 95041a (USNM loc. 37n) and 724161-724165 (USNM 44282), 724167-724170 (USNM 44279), 724171-724176 (USNM 44282).

Diagnosis.-Cranidium having a stronger curved anterior border, longer preglabellar area (sag. in dorsal view), flexure of preglabellar area to anterior border broadly rounded.

Occurrence.-Lakeview Limestone (Ptychagnostus praecurrens Zone), Pend Oreille Lake, Idaho (Resser, 1938a). Spence Shale (Glossopleura walcotti Zone), Antimony Canyon, Wellsville Mountains, Utah (Campbell, 1974).
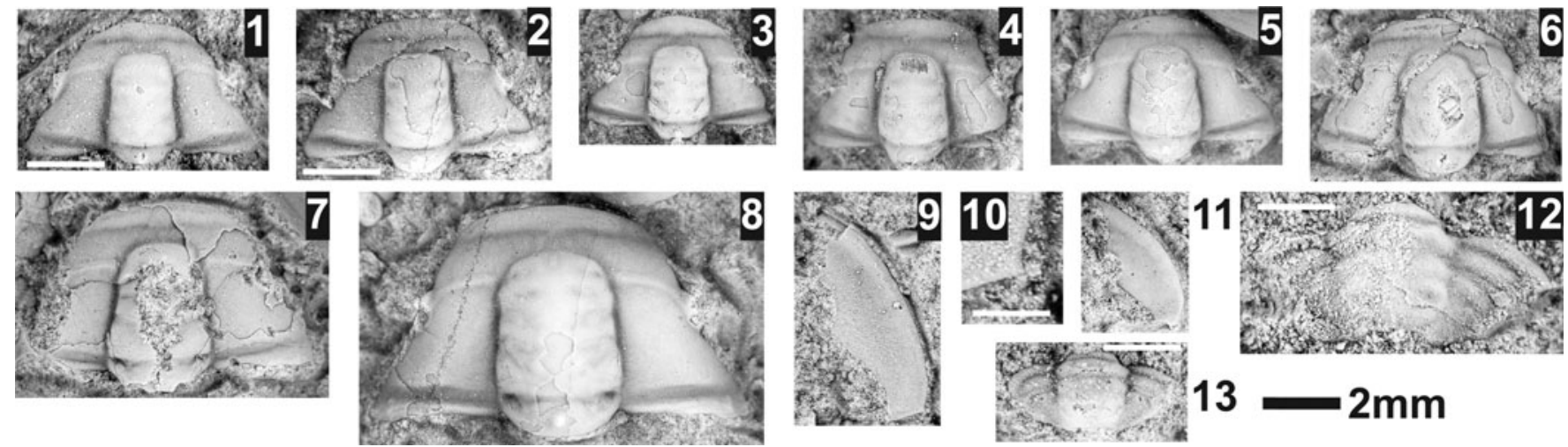

Figure 34. Elrathina cf. idahoensis (Resser, 1938a), from the Ptychagnostus praecurrens Zone, Lakeview Limestone, Pend Oreille Lake, Idaho. White bars are 1 mm scale, all others use the $2 \mathrm{~mm}$ scale. All specimens from USNM loc. 44283. (1) Exfoliated cranidium USNM 724006; (2) mostly exfoliated cranidium USNM 724001; (3) mostly testate cranidium USNM 724007; (4) mostly testate cranidium USNM 724008; (5) mostly testate cranidium USNM 724000; (6) partially testate cranidium USNM 724009; (7) partially testate, damaged cranidium USNM 724003; (8) partially testate cranidium USNM 723199; (9, 10) exfoliated librigena USNM 724004, and close-up of genal angle; (11) exfoliated librigena USNM 724005; (12) partially testate pygidium USNM 724010; (13) testate pygidium USNM 724002. 

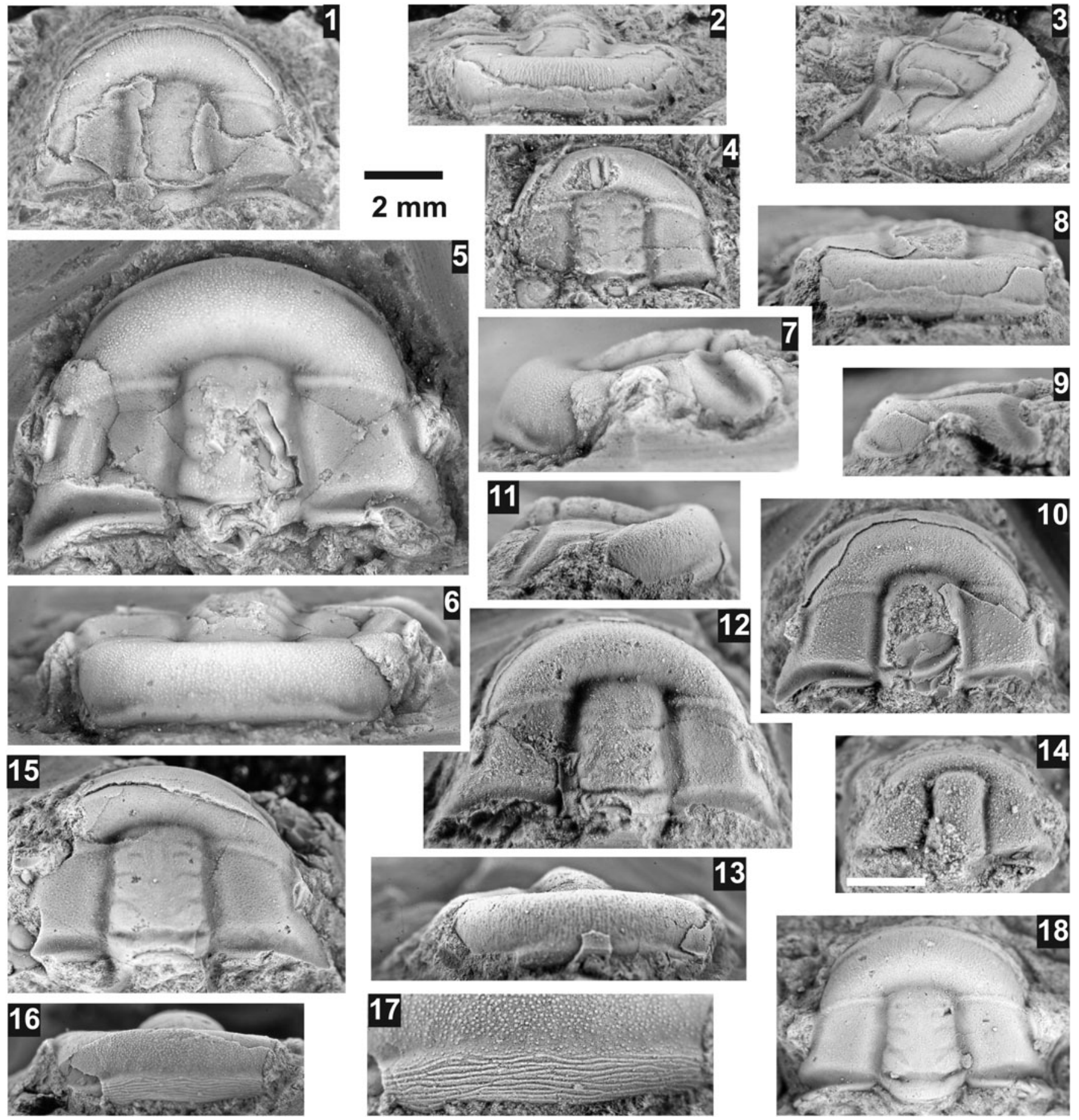

Figure 35. Utia debra n. sp. from the Lakeview Limestone, Pend Oreille Lake. (1-4) Resser's (1938a) illustrated specimens USNM 95041 (USNM loc. 37n). (1-3) Mostly exfoliated paratype cranidium USNM 356b, dorsal, anterior, and lateral-oblique views; (4) damaged, mostly exfoliated paratype cranidium USNM 356a. (518) Specimens from this study. (5-7) Mostly testate, holotype cranidium USNM 724166 (USNM loc. 44280), dorsal, anterior, and lateral views; (8-10) mostly exfoliated paratype cranidium USNM 724162 (USNM loc. 44279), anterior, lateral, and dorsal views; (11-13) mostly exfoliated paratype cranidium USNM 724161 (USNM loc. 44279), lateral, dorsal, and anterior views; (14) testate small paratype cranidium USNM 724165 (USNM loc. 44279), white scale bar 1 mm; (1517) mostly exfoliated paratype cranidium USNM 724163 (USNM loc. 44279) illustrating granular ornamentation on preglabellar area and terrace lines on anterior border, dorsal, anterior, and anterior close-up views; (18) mostly exfoliated paratype cranidium USNM 724167 (USNM loc. 44279).

nearly flat, very slightly depressed in intraocular regions, level, anterior area strongly downsloping, lateral portions more strongly downsloping; width $78 \pm 3 \%$ glabellar width (K2). Palpebral lobes nearly straight, upturned, narrow and short, length $33 \pm 2 \%$ glabellar length; anterior margin located opposite L3 lobe. Ocular ridge moderate, slightly arched, directed slightly posterolaterally from glabella at $77 \pm 3^{\circ}$ to axis, separated from glabella by axial furrows. Posterior area of fixigena triangular, terminated with acute corner; length $45 \pm 5 \%$ glabellar length; width $81 \pm 7 \%$ glabella length. Posterior boarder strongly convex, narrow, boarder furrow deep, broadens laterally. 

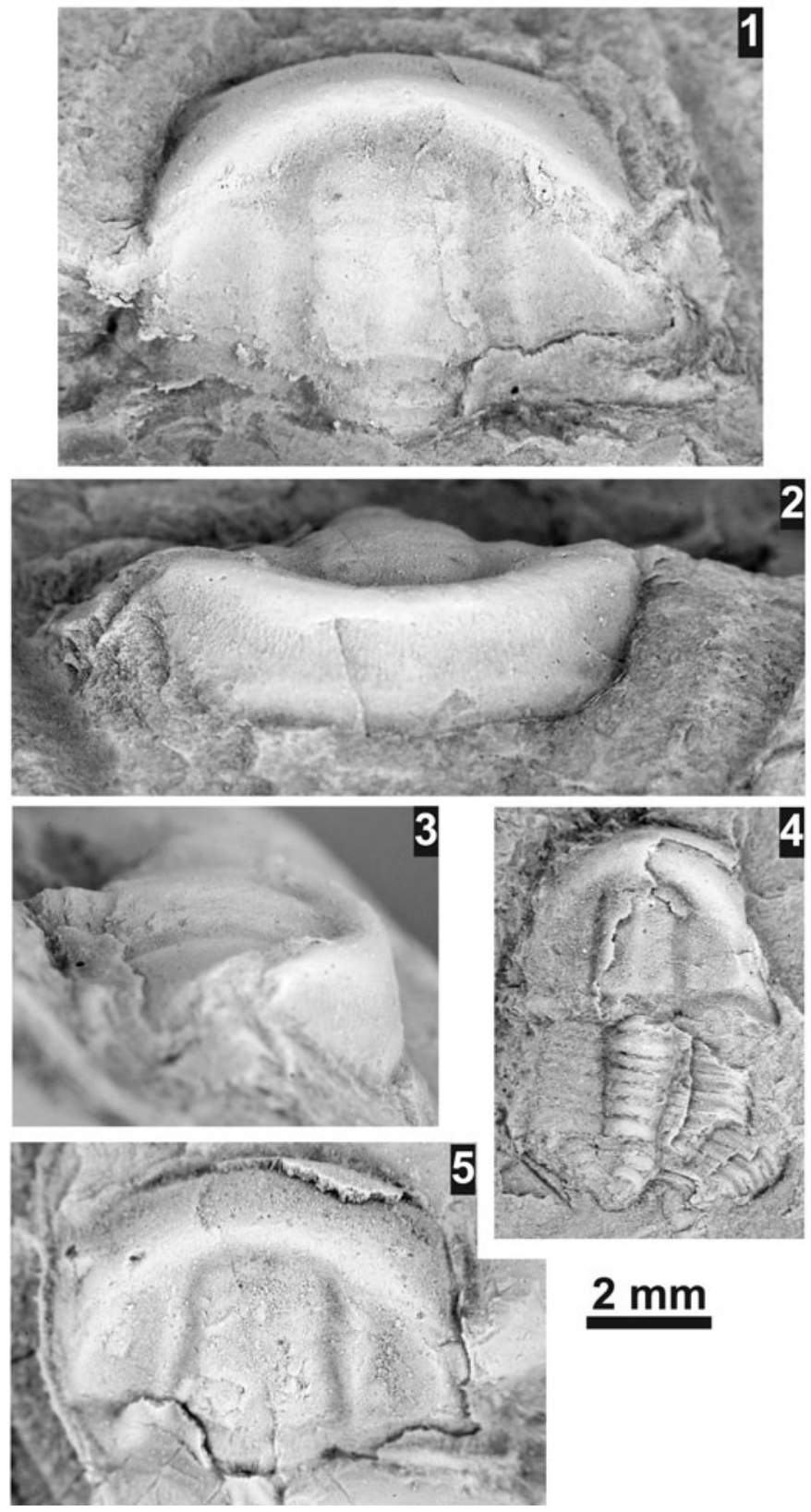

Figure 36. Utia curio Walcott, 1924, type specimens from the Spence Shale, Utah, USNM loc. 55c. (1-3) Mostly exfoliated lectotype cranidium USNM 70235, dorsal, anterior, and lateral views; (4) mostly exfoliated paralectotype cranidium and partial thorax USNM 70237; (5) mostly exfoliated paralectotype cranidium USNM 70235.

Granules scattered on frontal area, fixigena, occipital ring, and top of glabella. Anterior border with terrace lines. Exfoliated surface of frontal area with genal caeca.

Librigenae, rostral plate, hypostome, thorax, and pygidium unknown.

Etymology.—Named for my wife, Debra, who has continuously supported me in my research on trilobites.

Remarks.-The types U. curio (Fig. 36) are mostly exfoliated, have a relatively thick exoskeleton, and are preserved in shale, but do not appear to be compressed. Utia curio?
(Sundberg, 2018, p. 39-40, fig. 20.1-20.3) from the Emigrant Formation and from the Gordon Shale, Montana (Schwimmer, 1973), are here confirmed to belong to the species. Cranidium of $U$. debra n. sp. differ from U. curio in the latter having a slightly curved anterior border, a shorter preglabellar area in dorsal view, and a sharper flexure of the preglabellar area dorsally toward the anterior border. Campbell (1974) illustrated two additional specimens that can be assigned to U. debra $\mathrm{n}$. sp. from the Glossopleura walcotti Zone, Spence Shale, Utah.

Nearly all the Lakeview Limestone specimens (Fig. 35) are mostly or completely exfoliated. Where the exoskeleton is preserved, fine granules cover the marginal fixigena and frontal area, but are reduced in the palpebral lobe area and absent on the glabella and terrace lines cross the anterior border. Small meraspids have granules covering the entire cranidium. Prominent to faint genal caeca cross the frontal area on exfoliated specimens, but is not seen on the dorsal surface.

Ptychoparioid hypostome indet.

Figure 13.5-13.6

Remarks.-Ptychoparioid hypostomes were found, but their generic affiliation cannot be assessed.

\section{Acknowledgments}

M.S. Florence (USNM), C.C. Labandeira (USNM), J. Gillette (Museum of Northern Arizona-MNA), and D. Gillette (MNA) kindly arranged the loan of Resser's and Walcott type specimens. J.R. Laurie (Geoscience Australia), E.B. Naimark (Russian Academy of Sciences), S.R. Westrop (University of Oklahoma), and P. Ahlberg (Lund University) provided advice on the agnostids from the Lakeview Limestone. L.B. and M.B. McCollum (Eastern Washington University) provided many of the specimen collections as well as the measured section. J. Foster (Utah Field House of Natural History State Park Museum), L.B. McCollum, and J.K.F. Kimming (University of Kansas) provided comments on an earlier version of the manuscript. The generous help from these individuals is greatly appreciated. Constructive reviews were provided by P. Jell and B. Pratt.

\section{References}

Babcock, L.E., Robison, R.A., Rees, M.N., Peng. S.C., and Saltzman, M.R., 2007, The Global boundary stratotype section and point (GSSP) of the Drumian Stage (Cambrian) in the Drum Mountains, Utah, USA: Episodes, v. 30, p. 85-95.

Babcock, L.E., Peng, S.C., and Ahlberg, P., 2016, Cambrian trilobite biostratigraphy and its role in developing an integrated history of the Earth system: Lethaia, v. 50, p. 381-399.

Beecher, C.E., 1897, Outline of a natural classification of the trilobites: American Journal of Science, Series 3, 4, p. 89-106, 181-207.

Bergeron, J, 1899, Etude de quelques trilobites de Chine: Bulletin de la Societé Géologique de France, $3^{\text {rd }}$ series, v. 27, p. 499-519.

Brögger, W.C., 1878, On paradoxidesskifrene ved Krekling [About Paradoxides slates from Krekling]: Oslo, Naturvidenskaberne Kistiania, v. 24, p. $18-88$.

Browne, J.T., 2012, Geologic map of the Bayview and Lakeview quadrangles, Kootenai and Bonner counties, Idaho: Idaho Geological Survey, Technical Report 12-3, pl. 1.

Bush, J.H., 1989, The Cambrian System of northern Idaho and northwestern Montana, in Chamberlain, V.E., Breckenridge, R.M., and Bonnichsen, B., 
eds., Guidebook to the Geology of Northern and Western Idaho and Surrounding Area: Idaho Geological Survey Bulletin, v. 28, p. 103-121.

Bush, J.H., 1991, Cambrian paleogeographic framework for northeastern Washington, northern Idaho, and western Montana, in Cooper, J.D., and Stevens, C.H., eds., Paleozoic Paleogeography of the Western United States: III: SEPM-Pacific Section, v. 67, p. 463-473.

Bush, J.H., and Fischer, H.J., 1981, Stratigraphic and depositional summary for Middle and Upper Cambrian strata in northwestern Montana, northeastern Washington, and northern Idaho, in Taylor, M.E., ed., Short Papers for the Second International Symposium on the Cambrian System: U.S. Geological Survey Open File Report 81-743, p. 42-46.

Bush, J.H., Thomas, R.C., and Pope, M.C., 2012, Sauk megasequence deposition in northeastern Washington, northern Idaho, and western Montana, in Derby, J., Fritz, R., Longacre, S., Morgan, W., and Sternbach, C., eds., The Great American Carbonate Bank-The Geology and Economic Resources of the Cambrian-Ordovician Sauk Megasequence of Laurentia: American Association of Petroleum Geologists, Memoir, v. 98, p. 751768

Campbell, D.P., 1974, Biostratigraphy of the Albertella and Glossopleura zones (Lower Middle Cambrian) of Northern Utah and Southern Idaho [M.S. thesis]: University of Utah, Salt Lake City, 295 p.

Chernysheva, N.E., 1962, Kembriyskie trilobity semeystva Oryctocephalidae (Cambrian trilobites of the Family Oryctocephalidae), in Shvedov, N.A., ed., Problemy neftgazonosti Sovetskoy Arktiki. Paleontologiya biostratigrafiya, 3: Trudy Sibirskoy nauchno-issledovatel'skiy institut geologii Arktiki (NGA), Gostoptekhizdat, Leningrad, v. 127, p. 3-52.

Cooper, G.A., and Arellano, A.R.V., 1952, Introduction and stratigraphy, in Cooper, G.A., Arellano, A.R.V., Johnson, J.H., Okulitch, V.J., Stoyanow, A., and Lochman, C., Cambrian Stratigraphy and Paleontology near Caborca, Northwestern Sonora, Mexico: Smithsonian Miscellaneous Collections, v. 119, p. 1-26.

Eddy, J.D., and McCollum, L.B., 1998, Early Middle Cambrian Albertella Biozone trilobites of the Pioche Shale, southeastern Nevada: Journal of Paleontology, v. 72, p. 864-887.

Egorova, L.I., Shabanov, Yu.Ya., Rozanov, A.Yu., Savitskiy, V.E., Chenysheva, N.E., and Shishkin, B.B., 1976, Elanskiy i kuonamskiy fatsiostratotipy nizhney granitsy srednego kembriya Sibiri [Elanka and Kuonamka facies stratotypes of the lower boundary of the Middle Cambrian in Siberia] Sibirskiy Nauchno-issledovatel'skiy Institut Geologii, Geofiziki i Mineral'nogo Syr'ya, Trudy, v. 211, p. 1-167.

Etheridge, R., Jr., 1902, Official contributions to the palaeontology of South Australia. No. 13, Evidence of further Cambrian trilobites: South Australian Parliamentary Papers, p. 3-4.

Fortey, R.A., and Ruston, A.W.A., 1976, Chelidonocephalus trilobite fauna from the Cambrian of Iran: Bulletin of the British Museum of Natural History (Geology), v. 27, p. 321-340.

Foster, J.R., 2011, Trilobites and other fauna from two quarries in the Bright Angel Shale (Middle Cambrian, Series 3; Delamaran), Grand Canyon National Park, Arizona, in Hollingsworth, J.S., Sundberg, F.A., and Foster, J.R., eds., Cambrian Stratigraphy and Paleontology of Northern Arizona and Southern Nevada, The 16th Field Conference of the Cambrian Stage Subdivision Working Group, International Subcommission On Cambrian Stratigraphy Flagstaff, Arizona, And Southern Nevada, United States: Museum of Northern Arizona Bulletin, v. 67, p. 99-120.

Foster, J., 2014, Cambrian Ocean World, Ancient Sea Life of North America: Bloomington, Indiana, Indiana University Press, 416 p.

Fritz, W.H., 1968, Lower and early Middle Cambrian trilobites from the Pioche Shale, east-central Nevada, U.S.A: Palaeontology, v. 11, p. 183-235.

Geyer, G., and Peel, J.S., 2011, The Henson Gletscher Formation, North Greenland, and its bearing on the global Cambrian Series 2-Series 3 boundary: Bulletin of Geosciences, v. 86, p. 465-534.

Geyer, G., and Peel, J.S., 2017, Middle Cambrian trilobites from the Ekspedition Bræ Formation of Northern Greenland, and a reappraisal of the genus Elrathina: Journal of Paleontology, v. 91, p. 265-293.

Gunther, L.F., and Gunther, V.G., 1981, Some Middle Cambrian fossils of Utah: Brigham Young University Geology Studies, v. 28, pt. 1, 81 p.

Harrison, J.E., and Jobin, D.A., 1965, Geologic Map of the Packsaddle Mtn. Quadrangle, Idaho: United States Geological Survey, Map GQ-375, scale $1: 62,500,1$ sheet, $4 \mathrm{p}$

Huang, Y.Z., and Yuan, J.L., 1994, Peronopsis of Early-Middle Cambrian Kaili Formation from Kaili area, Guizhou: Acta Palaeontologica Sinica, v. 33, p. 295-304

Hupé, P, 1953, Classification des trilobites: Annales de Paléontologie, v. 39, p. $61-168$.

International Commission on Zoological Nomenclature, 1999, International Code of Zoological Nomenclature (4th edition): London, International Trust for Zoological Nomenclature, $106 \mathrm{p}$.

Jell, P.A., 1975, Australian Middle Cambrian eodiscoids with a review of the superfamily: Palaeontographica, Abt. A, v. 150, 97 p.
Kobayashi, T., 1935, The Cambro-Ordovician formations and faunas of South Chosen: Paleontology, pt. III: Cambrian faunas of South Chosen with special study on the Cambrian trilobite genera and families: Journal of the Faculty of Science Imperial University of Tokyo, section II, v. 4, p. 49-344.

Kobayashi, T., 1939, On the agnostids (Part 1): Journal of the Faculty of Science, Imperial University of Tokyo section II, v. 5, p. 69-198.

Korovnikov, I.V., and Shabanov, Y.Y., 2008, Trilobites from boundary rocks of Lower-Middle stratotype section on Molodo River (East of the Siberian Platform). Cambrian sections of the Siberian Platform-candidates for stratotypes of subdivisions of the International Stratigraphical scheme (Stratigraphy and Palaeontology), in Materials for 13th International Field Conference of the Cambrian Stage Subdivision Working Group. SB RAN, Novosibirsk, p. 71-104.

Laurie, J.R., 2004, Early Middle Cambrian faunas from NTGS Elkedra 3 corehole, southern Georgina Basin, Northern Territory, in Laurie, J.R., ed., Cambro-Ordovician Studies I: Memoirs of the Association of Australasian Palaeontologists, v. 30, p. 221-260.

Laurie, J.R, 2006, Early Middle Cambrian trilobites from Pacific Oil \& Gas Baldwin 1 Well, southern Georgina Basin, Northern Territory, in Paterson, J.R., and Laurie, J.R., eds., Cambro-Ordovician Studies II: Memoirs of the Association of Australasian Palaeontologists, v. 32, p. 127-204.

Lermontova, E.V., 1940. Klass Trilobita [Class Trilobita], in Vologdin, A.G., ed., Atlas rukovodyashchikh form iskopaemykh faun SSSR. Tom $1 \mathrm{Kem}-$ briy [Atlas of the leading forms of the fossil faunas of the USSR. Volume 1 Cambrian]: Gosudarstvennoe Izdatel'stvo Geologicheskoy Literatury, Moscow, Leningrad, p. 112-193.

Levi-Setti, R., 1993, Trilobites, Second Edition: Chicago, The University of Chicago Press, 342 p.

Lochman, C., 1952, Trilobites, in Cooper, G.A., Arellano, A.R.V., Johnson, J.H., Okulitch, V.J., Stoyanow, A., and Lochman, C., Cambrian Stratigraphy and Paleontology near Caborca, Northwestern Sonora, Mexico: Smithsonian Miscellaneous Collections, v. 119, p. 60-162.

M'Coy, F., 1849, On the classification of some British fossil Crustacea, with notices of new forms in the university collections at Cambridge: Annals and Magazine of Natural History, Series 2, v. 4, p. 161-179, 392-414.

Matthew, G.F., 1899, Studies on Cambrian faunas, number 3: Transactions of the Royal Society of Canada, v. 5, p. 39-66.

McCollum, L.B., and Sundberg, F.A., 2007, Cambrian trilobite biozonation of the Laurentian Delamaran Stage in the southern Great Basin, U.S.A.: implications for global correlations and defining a Series 3 global boundary stratotype, in Laurie, J.R., and Paterson, J.R., eds., Papers in Honour of John H. Shergold 1938-2006: Memoirs of the Association of Australasian Palaeontologists, v. 34, p. 147-156.

McKee, E.D., and Resser, C.E., 1945, Cambrian history of the Grand Canyon region: Carnegie Institution of Washington Publication 563, $232 \mathrm{p}$.

Meek, F.B., 1870, Description of fossils collected by the U. S. Geological Survey under the charge of Clarence King, Esq.: Proceeding of the Academy of the Natural Sciences of Philadelphia for 1870 , v. 22, p. 56-64.

Meek, F.B., 1873, Preliminary palaeontology report, consisting of list and descriptions of fossils, with remarks on the age of the rocks in which they are found: Annual Report of the United States Geological Survey of Territories, v. 6, p. 429-518.

Motzer, E.B., 1980, Paleoenvironments of the lower Lakeview Limestone (Middle Cambrian), Bonner County, Idaho [M.S. thesis]: Moscow, Idaho, University of Idaho, $174 \mathrm{p}$.

Naimark, E.B., 2012, Hundred species of the genus Peronopsis Hawle et Corda, 1847: Palaeontological Journal, v. 46, p. 945-1057.

Naimark, E.B., and Pegel, T.V., 2017, Revision of the Cambrian Agnostina (Trilobita?) from Russia: Palaeontological Journal, v. 51, p. 1167-1248.

Öpik, A.A., 1979, Middle Cambrian agnostids: systematics and biostratigraphy: Commonwealth of Australia Bureau of Mineral Resources, Geology and Geophysics, Bulletin 172, 2 vol., 188 p.

Pack, F.J., 1906, Cambrian fossils from the Pioche Mountains, Nevada: Journal of Geology, v. 14, p. 290-302.

Palmer, A.R., 1954, An appraisal of the Great Basin Middle Cambrian trilobites described before 1900: United States Geological Survey, Professional Paper 264D, p. 53-85.

Palmer, A.R., and Halley, R.B., 1979, Physical stratigraphy and trilobite biostratigraphy of the Carrara Formation (Lower and Middle Cambrian) in the southern Great Basin: United States Geological Survey Professional Paper $1047,131 \mathrm{p}$.

Peng, S., Babcock, L.E., Zhu, X., Lei, Q., and Dai, T., 2017, Revision of the oryctocephalid trilobite genera Arthricocephalus Bergeron and Oryctocarella Tomashpolskaya and Karpinski (Cambrian) from South China and Siberia: Journal of Paleontology, v. 91, p. 933-959.

Rasetti, F., 1951, Middle Cambrian stratigraphy and faunas of the Canadian Rocky Mountains: Smithsonian Miscellaneous Collections, v. 116, 277 p.

Rasetti, F, 1966, Revision of the North American species of the Cambrian trilobite genus Pagetia: Journal of Paleontology, v. 40, p. 502-511. 
Raymond, P.E., 1913, On the genera of the Eodiscidae: The Ottawa Naturalist, v. 27 , p. 101-106.

Raymond, P.E., 1928, Two new Cambrian trilobites: American Journal of Science, series 5, v. 15, p. 309-313.

Reed, F.R.C., 1899, Woodwardian Museum notes: a new trilobite from Mount Stephen, Field, B. C.: Geological Magazine, new series, v. 6, p. 358-361.

Resser, C.E., 1935, Nomenclature of some Cambrian trilobites: Smithsonian Miscellaneous Collections, v. 93, n. 5, 29 p.

Resser, C.E., 1937, Third contribution to nomenclature of Cambrian trilobites: Smithsonian Miscellaneous Collections, v. 95, n. 22, 29 p.

Resser, C.E., 1938a, Middle Cambrian fossils from Pend Oreille Lake, Idaho: Smithsonian Miscellaneous Collections, v. 97, n. 3, 12 p.

Resser, C.E., 1938b, Fourth contribution to nomenclature of Cambrian fossils: Smithsonian Miscellaneous Collections, v. 97, n. 10, 43 p.

Resser, C.E., 1939a, The Spence Shale and its fauna: Smithsonian Miscellaneous Collections, v. 97, n. 12, 29 p.

Resser, C.E., 1939b, The Ptarmigania Strata of the northern Wasatch Mountains: Smithsonian Miscellaneous Collections, v. 98, n. 24, 72 p.

Richter, R., 1932, Crustacea (Paläontologie), in Dittler, R., Joos, G., Korschelt, E., Linek, G., Oltmanns, F., and Schaum, K., eds., Handwörterbuch der Naturwissenschaften, 2nd ed.: Jena, Gustav Fischer, p. 840-864.

Robison, R.A., 1964, Late Middle Cambrian faunas from western Utah: Journal of Paleontology, v. 38, p. 510-566.

Robison, R.A., 1976, Middle Cambrian trilobite biostratigraphy of the Great Basin, in Robison, R.A., and Rowell, A.J., eds., Paleontology and depositional environments: Cambrian of western North America: Brigham Young University Geology Studies, v. 23, n. 2, p. 93-109.

Robison, R.A., 1978, Origin, taxonomy, and homeomorphs of Doryagnostus (Cambrian Trilobita): University of Kansas Paleontological Contributions, Paper 91, $11 \mathrm{p}$.

Robison, R.A., and Babcock, L.E., 2011, Systematics, paleobiology, and taphonomy of some exceptionally preserved trilobites from Cambrian Lagerstätten of Utah: University of Kansas Paleontological Contributions, v. 5, 47 p.

Robison, R.A., and Campbell, D.P., 1974, A Cambrian corynexochoid trilobite with only two thoracic segments: Lethaia, v. 7, p. 273-282.

Robison, R.A., Babcock, L.E., and Gunther, V.G., 2015, Exceptional Cambrian fossils from Utah, a window into the age of trilobites: Utah Geological Survey, Miscellaneous Publication 15-1, $97 \mathrm{p}$.

Rominger, C., 1887, Description of primordial fossils from Mount Stephens, N. W. Territory of Canada: Proceedings Academy of Natural Sciences Philadelphia, 1887, p. 12-19.

Salter, J.W., 1864, A monograph of British trilobites, Part 1: Palaeontolographical Society Monograph for $1862,80 \mathrm{p}$.

Schwimmer, D.R., 1973, The Middle Cambrian biostratigraphy of Montana and Wyoming [Ph.D. dissertation]: State University of New York, Stony Brook, $452 \mathrm{p}$.

Shabanov, Yu.Ya., Korovnikov, I.V., Pereladov, V.S., and Fefelov, A.F., 2008, The traditional Lower-Middle Cambrian boundary in the Kuonamka Formation of the Molodo River section (the southeastern slope of the Olenek Uplift of the Siberian Platform) proposed as a candidate for GSSP of the lower boundary of the Middle Cambrian and its basal (Molodian) stage defined by the FAD of Ovatoryctocara granulata, in Rozanov, A.Yu., Varlamov, A.I., Parkhaev, P.Yu., and Pack, K. L., eds., The Cambrian System of the Siberian Platform, Part 2: North-east of the Siberian Platform: MoscowNovosibirsk PIN RAS, p. 8-59.

Shergold, J.H., 1969, Oryctocephalidae (Trilobita: Middle Cambrian) of Australia: Commonwealth of Australia Bureau of Mineral Resources, Geology and Geophysics, Bulletin, v. 104, 66 p.

Stewart, J.H., 1970, Upper Precambrian and Lower Cambrian strata in the southern Great Basin California and Nevada: United States Geological Survey Professional Paper 620, $206 \mathrm{p}$.

Sundberg, F.A., 1994, Corynexochida and Ptychopariida (Trilobita, Arthropoda) of the Ehmaniella Zone (Middle Cambrian), Utah and Nevada: Los Angeles County Museum of Natural History, Contributions in Science, no. $446,137 \mathrm{p}$

Sundberg, F.A., 2000, Homeotic evolution in Cambrian trilobites: Paleobiology, v. 26, p. 258-270.

Sundberg, F.A., 2005, The Topazan Stage, a new Laurentian Stage (Lincolnian Series-"Middle" Cambrian): Journal of Paleontology, v. 79, p. 63-71.

Sundberg, F.A., 2011a, Delamaran biostratigraphy and lithostratigraphy of Southern Nevada, in Hollingsworth, J.S., Sundberg, F.A., and Foster, J.R., eds., Cambrian Stratigraphy and Paleontology of Northern Arizona and Southern Nevada, The 16th Field Conference of the Cambrian Stage Subdivision Working Group, International Subcommission on Cambrian Stratigraphy, Flagstaff, Arizona, and Southern Nevada, United States: Museum of Northern Arizona Bulletin, v. 67, p. 174-185.

Sundberg, F.A., 2011b, Chisholm Shale (Glossopleura walcotti zone, upper Delamaran, Global Stage 5) at the Half Moon Mine, Pioche Nevada, in
Hollingsworth, J.S., Sundberg, F.A., and Foster, J.R., eds., Cambrian Stratigraphy and Paleontology of Northern Arizona and Southern Nevada, The 16 th Field Conference of the Cambrian Stage Subdivision Working Group, International Subcommission on Cambrian Stratigraphy, Flagstaff, Arizona, and Southern Nevada, United States: Museum of Northern Arizona Bulletin, v. 67, p. 174-185.

Sundberg, F.A., 2014, Phylogenetic analysis of the spiny oryctocephalids (Trilobita, Corynexochida?, Oryctocephalidae), Cambrian: Journal of Paleontology, v. 88, p. 224-226.

Sundberg, F.A., 2018, Trilobite biostratigraphy of the Cambrian 5 and Drumian stages, Series 3 (Laurentian Delamaran, Topazan, and Marjuman stages, Lincolnian Series) of the lower Emigrant Formation at Clayton Ridge, Esmeralda County, Nevada: Journal of Paleontology Memoir 76, 44 p.

Sundberg, F.A., and McCollum, L.B., 1997, Oryctocephalids (Corynexochida: Trilobita) of the Lower-Middle Cambrian boundary interval from California and Nevada: Journal of Paleontology, v. 71, p. 1065-1090.

Sundberg, F.A., and McCollum, L.B., 2000, Ptychopariid trilobites of the Lower-Middle Cambrian boundary interval, Pioche Shale, Southeastern Nevada: Journal of Paleontology, v. 74, p. 604-630.

Sundberg, F.A., and McCollum, L.B., 2003, Early to Mid Cambrian trilobites of the outer shelf deposits of Nevada and California: Palaeontology, v. 42, p. $945-986$.

Swinnerton, H.H., 1915, Suggestions for a revised classification of trilobites: Geological Magazine (new series), v. 6, p. 487-496, 538-545.

Tomashpolskaya, V.D., and Karpinski, R.B., 1961, Some Middle Cambrian trilobites from the region of the village Sukhaya Erba (Batenevsky Ridge): Izvestiya Tomskogo Polytekhnicheskogo Instituta, v. 120, p. 152-160. [in Russian]

Walcott, C.D., 1886, Second contribution to the studies on the Cambrian fauna of North America: Bulletin of the United States Geological Survey, v. 30, p. $1-369$.

Walcott, C.D., 1888, Cambrian fossils from Mount Stephens, Northwest Territory of Canada: American Journal of Science, series 3, v. 36, p. 163-166.

Walcott, C.D., 1889, Description of new genera and species of fossils from the Middle Cambrian: Proceedings of the Unites States National Museum, v. 11, p. 441-446.

Walcott, C.D., 1908, Cambrian geology and paleontology, 2, Cambrian trilobites: Smithsonian Miscellaneous Collections, v. 53, p. 13-52.

Walcott, C.D, 1916a, Cambrian geology and paleontology III, Cambrian trilobites: Smithsonian Miscellaneous Collections, v. 64, n. 3, p. 157-258.

Walcott, C.D., 1916b, Cambrian geology and paleontology III, Cambrian trilobites: Smithsonian Miscellaneous Collections, v. 64, n. 5, p. 303-456.

Walcott, C.D., 1924, Cambrian and Lower Ozarkian trilobites. Cambrian geology and paleontology, pt. 5: Smithsonian Miscellaneous Collections, v. 75, n. 2 , p. $53-60$.

Walcott, C.D., 1925, Cambrian geology and paleontology V, Cambrian and Ozarkian trilobites: Smithsonian Miscellaneous Collections, v. 75, n. 3, p. 61-146.

Webster, M., and Sheets, H.D., 2010, A practical introduction to landmarkbased geometric morphometrics, in Alroy, J., and Hunt, G., eds., Quantitative Methods in Paleobiology: Paleontological Society Papers, v. 16, p. $163-188$.

Westergård, A.H., 1936, Paradoxides oelandicus beds of Öland: Sveriges Geologiska Undersökning, Series C, v. 394, 66 p.

White, C.A., 1874, Preliminary report upon invertebrate fossils collected by the expeditions of 1871,1872 , and 1873 , with description of new species: United States Geographic Exploration West 100th Meridian (Wheeler), Washington, Government Printing Office, $27 \mathrm{p}$.

Whittington, H.B., 1995, Oryctocephalid trilobites from the Cambrian of North America: Palaeontology, v. 38, p. 543-562.

Yuan, J.L., Zhao, Y.L., Peng J., Zhu X. and Lin, J.P., 2009, Cambrian trilobite Ovatoryctocara granulata Tchernysheva, 1962 and its biostratigraphic significance: Progress in Natural Science, v. 19, p. 213-221.

Zhao, Y., Yuan, J.-L., Babcock, L.E., Guo, Q.-J., Peng, J., Yin, L., Yang, X., Peng, S.C., Wang, C., Gaines, R.R., Esteve, J., Tai, T.S., Yang, R., Wang, Y., Sun, H.J., and Yan, Y., 2019, Global Standard Stratotype-Section and Point (GSSP) for the conterminous base of the Miaolingian Series and Wuliuan Stage (Cambrian) at Balang, Jianhe, Guizhou, China: Episodes, v. 42 , p. $165-184$.

\section{Appendix-Locality registry}

Section measured of Lakeview Limestone, one mile north of Lakeview along shore, $\mathrm{N}^{\circ} 7^{\circ} 59.400^{\prime}, \mathrm{W} 116^{\circ} 26.374^{\prime}$. Measured August 12, September 28, and October 4, 2003, by M.B. and L.B. McCollum. 
USNM locality 37n.-Resser's original Lakeview Limestone locality collected in 1921-1924, at a cement mine just north of Lakeview, Pend Oreille Lake, Idaho. Pentagnostus bonnerensis, Pagetia fossula, Oryctocephalus reynoldsi, Oryctocara geikiei, Athabaskia minor, Zacanthoides sampsoni, Kootenia sp., Utia debra, Elrathina idahoensis, Amecephalus noduliferus, Am. notatus, and Am. normale.

USNM locality 44278.--Material collected in 2003 by L.B. McCollum, from talus material at the base of a cliff next to the cement mine in Resser's locality. Abundances not listed due to the specimens collected from talus. Pentagnostus bonnerensis, Pagetia fossula, Oryctocephalus reynoldsi, Oryctocara geikiei, Athabaskia minor, Zacanthoides sampsoni, Kootenia sp., Utia debra n. sp., Elrathina idahoensis, Amecephalus noduliferus, Am. notatus, and Am. normale.

USNM locality 44279.-Material collected in 2003 by L.B. McCollum, $8 \mathrm{~m}$ stratigraphically above base of cliff next to the cement mine in Resser's locality. Pentagnostus bonnerensis (very abundant), Pagetia fossula (rare), Oryctocephalus reynoldsi (rare), Oryctocara geikiei (common), Thoracocare minuta (very rare), Athabaskia minor (very rare), Zacanthoides sampsoni (common), Kootenia sp. (very rare), Utia debra n. sp. (rare), Elrathina idahoensis (common), Amecephalus noduliferus (rare), Am. notatus (very rare), and Am. normale (rare).

USNM locality 44280.-Material collected in 2003 by L.B. McCollum, 9.5-10.5 m stratigraphically above base of cliff next to the cement mine in Resser's locality. Pentagnostus bonnerensis (common), Pagetia fossula (common), Thoracocare minuta (very rare), Oryctocephalus reynoldsi (very rare), Oryctocara geikiei (very rare), Athabaskia minor (rare), Zacanthoides sampsoni (rare), Kootenia sp. (very rare), Utia debra n. sp. (very rare), Elrathina idahoensis (common), Amecephalus noduliferus (very rare), Am. notatus (rare), and Am. normale (rare).

USNM locality 44281.-Material collected in 2003 by L.B. McCollum, 10.5-11.5 m stratigraphically above base of cliff next to the cement mine in Resser's locality. Pentagnostus bonnerensis (abundant), Pagetia fossula (rare), Oryctocephalus reynoldsi (rare), Oryctocara geikiei (rare), Athabaskia minor (very rare), Zacanthoides sampsoni (rare), Kootenia sp. (very rare), Elrathina idahoensis (common), and Am. normale (very rare).

USNM 44282.-Material collected in 2003 by L.B. McCollum, $11.75 \mathrm{~m}$ stratigraphically above base of cliff next to the cement mine in Resser's locality. Pentagnostus bonnerensis (abundant), Pagetia fossula (common), Oryctocephalus reynoldsi (very rare), Oryctocara geikiei (very rare), Thoracocare minuta (very rare), Athabaskia minor (very rare), Zacanthoides sampsoni (rare), Kootenia sp. (very rare), Utia debra n. sp. (rare), Elrathina idahoensis (common), Amecephalus noduliferus (very rare), Am. notatus (rare), and Am. normale (rare).

USNM 44283.--Material collected in 2005 by Sundberg, $18 \mathrm{~m}$ stratigraphically above base of cliff next to the cement mine in Resser's locality. The exposure was behind the support pillars of the loading hopper. Itagnostus idahoensis n. sp. (abundant), Pagetia fossula (very rare), Athabaskia sp. indet. (very rare), Oryctocephalus reynoldsi (abundant), Zacanthoides sampsoni (very rare), and Elrathina cf. idahoensis (rare).

Chisholm Shale, Half Moon Mine area, Pioche Hills, Lincoln County, Nevada.

USNM 31.-Material collected by Walcott in 1885 , shales at the Chisholm Mine, southwest slope of Ely Mountains, 3 miles northwest of Pioche, Lincoln County, Nevada.

USNM 44284.-Material collected in 2018 by author, N37 $55.921^{\prime} \mathrm{W} 114^{\circ} 29.328^{\prime}$, elevation $2,071 \mathrm{~m}$ (6833.8 $\mathrm{ft}$.). Collected Am. piochensis from near the Half Moon Mine. Approximately $3 \mathrm{~m}$ interval of brown/ greenish brown shale or white to brownish orange color near the eastern extent of exposure next to or from the two adits.

USNM 44285.- Specimen collected in 2018 by Debra WhitneySundberg from shale talus of the Half Moon Mine.

Accepted: 27 May 2020 